ARCHIWA, BIBLIOTEKII MUZEA KOSCIELNE. T. 11

O. KORNEL GADA.CZ OFM Cap.

\title{
INWENTARZ ZBIORÓW SZTUKI PROWINCJI KRAKOWSKIEJ ZAKONU OO. KAPUCYNOW
}




\section{PRZEDMOWA}

Inwentarz niniejszy powstał $\mathrm{w}$ drugiej połowie $1963 \mathrm{i} \mathrm{w}$ pierwszych miesiącach 1964 r. Rejestruje on zbiory sztuki, będące w posiadaniu czterech klasztorów kapucyńskich prowincji krakowskiej. Obejmuje wyłącznie obrazy, grafikę, rzeźby i płaskorzeźby, epitafia i inskrypcje oraz klisze drukarskie. Dalsze obiekty sztuki jak złotnictwo, tkaniny $i$ in. znajdą się $w$ drugim tomie.

Inwentarz został ujęty pod kątem widzenia archiwalno-historycznym, dlatego główny nacisk położono na stronę opisowo-historyczną. Ażeby jednak zadośćuczynić, przynajmniej $\mathrm{w}$ minimalnym stopniu, wymaganiom i potrzebom współczesnej wiedzy, należało przeanalizować trudniejsze zagadnienia z historykami sztuki. Udzielili oni podpisanemu wiele cennych uwag z zakresu swoich sepcjalności.

Dlatego autor poczuwa się do miłego obowiązku, ażeby złożyć podziękowanie tym wszystkim, którzy chętnie słuzyli radą i pomocą.

P. dr Jan Samek z Zakładu Historii Sztuki UJ przedyskutował z podpisanym stronę techniczną inwentarza.

P. doc. dr Kazimierz Buczkowski rozwiązał kilka spornych problemów.

P. mgr Tadeusz Chrzanowski sprawdził techniki malarskie i czas powstania niektórych obiektów w klasztorze krakowskim. Dopomógł również w opisie kilku epitafiów i ocenił manuskrypt.

P. mgr Zofia Alberowa i p. Maria Dzieduszycka z Muzeum Narodowego w Krakowie opisały japońskie drzeworyty (nr 261-268).

P. Jadwiga Śliwińska z Muzeum Narodowego poddała konserwacji średniowieczną Madonnę.

P. mgr Jerzy Werner z Akademii Sztuń Pięknych sprawdzil technikę grafiki i dopomógł w opisie klisz drukarskich.

Ks. dr Bolesław Przybyszewski i p. doc. dr Józef Lepiarczylk zechcieli przejrzeć i poddać ocenie rękopis.

Przy pomiarach obiektów pomagali sporadycznie niektórzy bracia i klerycy kapucyńscy. Specjalna wdzięczność należy się p. inż. Eugeniuszowi Wójcikowi za pomoc $\mathrm{w}$ wylkonaniu pomiarów figury Madonny (Kraków $\mathrm{nr}$ 1) oraz obrazów znajdujących się w zwieńczeniach ołtarzy w kościele OO. Kapucynów w Krakowie.

Pracę tę dedykuję O. Prowincjałowi mgr Alojzemu Wojnarowi. Autor będzie szczęśliwy, jeżeli ona przyczyni się do zabezpieczenia i poszanowania zbiorów sztuki w klasztorach kapucyńskich. 


\section{WYKAZY POMOCNICZE}

\section{SKROTTY NAZW ARCHIWOW I BIBLIOTEK}

AKK - Archiwum Klasztoru OO. Kapucynów w Krakowie

AKKR - Archiwum Klasztoru OO. Kapucynów w Krośnie

AKO - Archiwum Klasztoru OO. Kapucynów w Olesku (w depozycie APK)

AKR - Archiwum Klasztoru OO. Kapucynów w Rozwadowie

AKS - Archiwum Klasztoru OO. Kapucynów w Sędziszowie

AKUT - Archiwum Klasztoru OO. Kapucynów w Kutkorzu (w depozycie APK)

AKZ - Archiwum Klasztoru OO. Kapucynów we Lwowie-Zamarstynowie (w depozycie APK)

APK - Archiwum Prowincji Krakowskiej OO. Kapucynów

Arch. Un. Jag. - Archiwum Uniwersytetu Jagiellońskiego

Bibl. Un. Warsz. - Biblioteka Uniwersytetu Warszawskiego

\section{WYKAZ CZEŚSIEJ CYTOWANYCH REKKOPISÓW}

AKK, rkps 17: Rozporządzenia wladz świeckich 1796-1882. (Cyt.: AKK, rkps 17: Rozporządzenia).

AKK, rkps 19: Organizacja klasztoru. Korespondencja. Zabytki. (Cyt.: AKK, rkps 19: Organizacja klasztoru).

AKK, rkps 38: Inwentarz sprzętów kościelnych i klasztornych Xięży Kapucynów Krakowskich z wyszczególnieniem, co przybyło lub ubyło, spisany z polecenia Przewielebnego Ojca Benjamina Prowincjała pod gwardianią Ojca Filipa [Szumowskiego]. Podany w drugim egzemplarzu na Kapitułę Nowomiejską dnia 20 września 1839 r. (Cyt.: AKK, rkps 38: Inwentarz z r. 1839).

AKK, rkps 39: Inwentarze kościoła i klasztoru OO. Kapucynów w Krakowie od r. 1798-1936. (Cyt.: AKK, rkps 39: Inwentarz [z podaniem odpowiedniego roku]).

AKK, rkps 40: Inwentarz klasztoru OO. Kapucynów w Krakowie sporządzony wskutek rozporządzeń Wysokiego CK Namiestnictwa we Lwowie z dnia 6 lutego 1870. L. 2070 za staraniem ówczesnego gwardiana ks. Wiktora Klimka, definitora Zakonu OO. Kapucynów Prowincji Galicyjskiej Kraków, dnia 12 kwietnia 1875. (Cyt.: AKK, rkps 40: Inwentarz z r. 1875).

AKK, rkps 46: Sepultı in ecclesia nostra saeculares. Fundatores et benefactores nostri sunt sepulti in ecclesia et cemeterio ab initio fundationis nostri Conventus et Ecclesiae Cracoviensis O.S. P. Fr. Capucinorum. (Cyt.: AKK, rkps 46: Sepulti in ecclesia nostra saeculares).

AKK, rkps - Historia Conventus nostri Capucinorum Cracoviensium. T. I-II. [Od t. III pt.:] Kronika klasztoru OO. Kapucynów w Krakowie (Cy.t.: AKK, rkps HCC).

AKKR, rkps 3: Organizacła klasztoru. Inwentarze 1791-1918. (Cyt.: AKKR, rkps 3: Inwentarz [z podaniem odpowiedniego roku]).

AKKR, rkps - Chronologia Conventus. Liber secundus, tertius et quartus. (Cyt.: AKKR, rkps CCC II-IV).

AKR, rkps - Chronologia seu Historia Conventus Rosvadoviensis P. P. Capucinorum. T. I: A fundatione ab anno 1740 usque ad a. 1862. T. II: Ab anno 1862 usque ad a. 1908 (Cyt.: AKR, rkps HCR I-II).

AKR, rkps - Kronika klasztoru rozwadowskiego od 15 listopada 1917 r. (Cyt.: AKR, rkps: Kronika klasztoru od 1917).

AKR, rkps - Kronika klasztoru OO. Kapucynów w Rozwadowie. Od roku 1935. (Cyt.: AKR, rkps: Kronika klasztoru od 1935).

AKR, rkps - Kronika klasztoru OO. Kapucynów w Rozwadowie (od roku 1947). (Cyt.: AKR, rkps: Kronika klasztoru od 1947).

AKS, rkps 5: Copia Inventarii Buchhalterici de anno 1827 facti in Conventu Sendziszoviensi PP Capucinorum sub Nro 185. (Cyt.: AKS, rkps 5: Copia Inventarii Buchhalterici).

AKS, rkps - Inwentarium des in dem Orte Sędziszow - Rzeszower Kreises gelegenen - zur Przemysler lat. Diecös gehörigen Kapuziner-Klosters zu Sędziszów. Welches in Grunde K. Gub. Verordnung vom 13. Junii 1826 z. 30827 und K. Kreisamtlichen Autrags vom 14 November 1826 Z. 8972 
neu aufgenommen worden ist. Zu Sędziszów am 14. September 1827. Copia Inventarii tempore Guardianatus P. Floriani ab Haczów facta a. $1885 \mathrm{~d}$. 11/12. (Cyt.: AKS, rkps: Inwentarz z r. 1827).

AKS, rkps - Kronika klasztoru OO. Kapucynów w Sędziszowie 1887-1914. (Cyt.: AKS, rkps: Kronika klasztoru 1887-1914).

AKS, rkps - Kronika klasztoru OO. Kapucynów w Sędziszowie od 1. I. 1936. (Cyt.: AKS, rkps: Kronika klasztoru od 1936).

AKS, rkps - Protocollum publicandorum PP Capucinorum Conventus Sędziszoviensis ab anno 1777. (Cyt.: AKS, rkps: Protocollum publicandorum).

APK, nr 118: Album cudownych obrazów Matki Bożej w Polsce. Zebrany przez o. Wacława Nowakowskiego. (Cyt.: AKP, $\mathrm{nr}$ 118: Album cudownych obrazów).

APK, rkps 148: Materiały do historii Zakonu Kapucyńskiego. (Cyt.: APK, rkps 148: Materiały).

APK, rkps - Brat Efrem Chmiel: Kronika klasztoru. Kraków 1935.- (Cyt.: APK, rkps - Br. E. Chmiel: Kronika).

APK, rkps 165: O. Zenon Gorlicki: Notatki do historii kapucynów w Polsce. (Cyt.: APK, rkps 165: O. Z. Gorlicki: Notatki).

APK, rkps 306: Brat Teofil Kowalik: Rozmaitości [Historia krakowskich kościołów i różne wspomnienia 1933-1940]. (Cyt.: APK, rkps 306: Br. T. Kowalik: Rozmaitości).

APK, rkps - O. Kornel Gadacz: Historia klasztoru OO. Kapucynów w Krakowie. Pierwsze ćwierćwiecze. Kraków 1948. (Cyt.: APK, rkps - O. K. Gadacz: Historia klasztoru).

APK, rkps - O. Paweł Kochański: Kościół Zwiastowania Najśw. Marii Panny OO. Kapucynów w Krakowie. Dzieje i zabytki. Kraków 1954. (Cyt.: APK, rkps - O. P. Kochański: Kościół Zwiastowania).

\section{SKRÓTY TYTUEOW CZASOPISM}

Arch. Bibliot. kośc.

Biul. Hist. Szt.

Collect. francis.

Dzwonek III Zak.

Gość niedz.

Ilustr. Kur. codz.

Ilustr. Kur. pol.

Kalend, francisz.

Kwart. hist.

Nowości ilustr.

Pr. Komis. Hist. Szt. PAU

Przyj. dom.

Przyj. Ludu

Pszczól. krak.

Rocz. krak.

Rocz-i TNTor.

Skarb Wierz.

Studies in Conserv.

Tyg. powsz.

Wiad. tercj.

Wiad. Prow. krak. Kapuc. - Wiadomości z Prowincji Krakowskiej OO. Kapucy-

Wojen, KAP

Wzlot seraf.

- Archiwa, Biblioteki i Muzea Kościelne

- Biuletyn Historii Sztuki

- Collectanea Franciscana

- Dzwonek III Zakonu S.O.N. Franciszka Serafickiego

- Gość Niedzielny

- Ilustrowany Kurier Codzienny

- Ilustrowany Kurier Polski

- Kalendarz Franciszkański

- Kwartalnik Historyczny

- Nowości Ilustrowane

- Prace Komisji Historii Sztuki PAU

- Przyjaciel Domowy

- Przyjaciel Ludu

- Pszczółka Krakowska

- Rocznik Krakowski

- Roczniki Towarzystwa Naukowego w Toruniu

- Skarb Wierzących

- Studies in Conservation

- Tygodnik Powszechny

- Wiadomości Tercjarskie

nów

- Wojenna Katolicka Agencja Prasowa

- Wzlot Seraficki

\section{WYKAZ CZESCREJ CYTOWANYCH WYDAWNICTW}

Allegemeines Lexicon der bildenden Künstler... zob. Thieme Ulrich, Becker Felix. Bénézit E.: Dictionaire critique et documentaire des peintres, sculpteurs, dessinateurs et graveurs. T. 1-8. Paris 1948-1954. (Cyt.: Bénézit).

Cercha Maksymilian, Cercha Stanisław: Pomniki Krakowa. Z tekstem Feliksa Kopery. T. 1-3. Kraków 1904. (Cyt.: M. i S. Cerchowie: Pomniki). 
Chwalewik Edward: Zbiory polskie. Archiwa, biblioteki, gabinety, galerie, muzea i inne zbiory pamiątek przeszłości w ojczyźnie i na obczyźnie. Wyd. 2. T. 1-2. Warszawa 1926-1927. (Cyt.: E. Chwalewik: Zbiory polskie).

Ciampi Sebastiano: Notizie di medici, maestni di musica e cantori, pittori, architetti, scultori et altri artistici italiani in Polonia e polacchi in Italia. Lucca 1830. (Cyt.: S. Ciampi: Notizie).

Gadacz Kornel o.: Inwentarz Archiwum Prowincji Krakowskiej OO. Kapucynów. Arch. Bibliot. kośc. T. 2: 1961 z. 1/2 s. 53-165. (Cyt.: O. K. Gadacz: Inwentarz Archiwum).

[Janocha] Florian o.: Loretto. Nabożeństwo loretańskie z nowenną do cudownej Najśw. Maryi Matki Bożej w świętym domku przy kościele OO. Kapucynów w Krakowie. Kraków 1899. (Cyt.: O. Florian [Janocha]: Loretto).

Lexicon capuccinum. Promptuarium historico-bibliographicum Ordinis Fratrum Minorum Capuccinorum (1525-1950). Romae 1951. (Cyt.: Lex. cap.).

[Majer Ambroży o.]: O. Ambroży z Krakowa: W dwuwiecze sędziszowskiego klasztoru (1779-1939). Wiad. z Prow. krak. Kapuc. R. 2: 1939 nr 2. (Cyt.: O. A. Majer: W dwuwiecze).

Nagler G[eorg] K[aspar]: Neues allgemeines Künstler Lexicon. T. 1-22. München 1835-1852. (Cyt.: Nagler).

[Nowakowski Wacław o.]: O cudownych obrazach w Polsce Przenajświętszej Matki Bożej wiadomości historyczne, bibliograficzne i ikonograficzne przez X. Wacława z Sulgostowa kapucyna. Z. 1-5. Kraków 1902. (Cyt. O. W. Nowakowski: O cudownych obrazach w Polsce).

[Nowakowski] Wacław o.: Pamiątka 200-letniej rocznicy przybycia do Krakowa OO. Kapucynów 1695 r. Kraków 1895. (Cyt.: O. W. Nowakowski: Pamiątka).

[Nowakowski Wacław o.]: Warszawa w 1794 r. [Napisał] Bronisław Szwarce [rzekomy autor]. Kraków 1894. (Cyt. [O. W. Nowakowski]: Warszawa w 1794 r.).

Nowy brewiarzyk tercjarski. Wyd. 13. Kraków 1928. (Cyt.: Nowy brewiarzyk).

Orańska Józefa: Szymon Czechowicz 1689-1775. Poznań 1948. (Cyt.: J. Orańska: Szymon Czechowicz).

Rastawiecki Edward: Słownik malarzów polskich tudzież obcych w Polsce osiadłych lub czasowo w niej przebywających. T. 1-3. Warszawa 1850. (Cyt.: Rastawiecki: Słownik malarzów polskich).

[Sarna Władysław ks.] X. Wład. S.: Kościół i klasztor OO. Kapucynów w Krośnie. Kraków 1891. Odp. z Dzwonka III Zak, R. 6: $1890 \mathrm{nr} 11$ s. 333-342. (Cyt.: Ks. W. S[arna]: Kościól i klasztor).

Skrudlik Mieczysław: Królowa Korony Polskiej. Szkice z historii malarstwa i kultu Bogarodzicy w Polsce. Lwów 1930. (Cyt.: M. Skrudlik: Królowa Korony Polskiej).

Skrudlik Mieczysław: [o klasztorze Oo. Kapucynów w Krakowie i znajdujących się w nim obrazach. Sprawozdanie z referatu]. Pr. Komis. Hist. Szt. PAU. T. 1: 1919 z. 1 s. XIV, t. 2: 1922 z. 2 s. LXXVI. (Cyt.: M. Skrudlik: O klasztorze OO. Kapucynów w Krakowie).

Skrudlik Mieczysław: Sw. Franciszek Seraficki w zabytkach malarstwa polskiego. W: Ojcu Serafickiemu $w$ hotdzie. Warszawa 1927. (Cyt.: M. Skrudlik: Sw. Franciszek Seraficki).

Thieme UIrich, Becker Felix [Wyd.]: Allegemeines Lexicon der bildenden Künstler von der Antike bis zur Gegenwart. Bd 1-37. Leipzig 1907-1950. (Cyt.: Thieme $u$. Becker).

Tomkowicz Stanisław: O artystach pracujacych w Polsce lub dla Polski. III: Wiek XVIII i XIX. Pr. Komis. Hist. Szt. PAU. T. 2: 1922 z. 2 s. LXXI-LXXVIII. (Cyt.: S. Tomkowicz: O artystach pracujacych w Polsce).

[Wojnar Alojzy o.]: Polski Loret. Historia Domku Najśw. Rodziny przy kościele OO. Kapucynów w Krakowie. Kraków 1939. (Cyt.: [O. A. Wojnar]: Polski Loret). 


\section{W S T E P}

I. Proweniencja dziełsztuki

\section{Obrazy, sztychy i rzeźby}

Pierwsze dzieła sztuki z natury rzeczy zdobiły kapucyńskie kościoły w charakterze czysto uzytkowym a więc liturgiczno-sakralnym. Niektóre z nich, z biegiem lat, zdezaktualizowały się i dlatego zostały wycofane na korytarze klasztorne. Ich miejsca zajęły aktualne wizerunki nowobeatyfikowanych lub kanonizowanych kapucynów względnie obrazy o innej treści. Najczęściej nowe partrety błogosławionych lub kanonizowanych zakonników umieszczano $w$ wielkim oltarzu na olsres uroczystych przejściowych nabozeństw a potem zawieszano je na ścianach kościoła lub klasztoru. Prawie $z$ reguły, tak $w$ chórze zakonnym jak i w refektarzu, znajdowały się cenne nieraz płótna i sztychy. Portrety fundatorów z naleznym szacunkiem lokowali zakonnicy na ścianach prezbiterium (Sędziszów), nagrobkach w kościele (Kraków), w chórze zakonnym (Kraków, Rozwadów, Olesko), lub w refelktarzu (Kraków, Rozwadów, Olesko). Refektarz uważano zawsze za reprezentacyjny ośrodek wspólnoty zakonnej, i dlatego tu można spotkać również portrety dobrodziejów kalsztoru, kardynałów-kapucynów, i biskupów Polaków z zakonu kapucyńskiego. Nalezy podkreślić ciekawe zjawisko - że portrety bardziej znanych i zasłuzonych polskich zakonników spotyka się dopiero na przełomie XIX i XX w. Tak w. XVIII jak i XIX, poza nielicznymi wyjątkami, nie pozostawił podobizn nawet sławnych kapucynów. Zapewne powodem była i pokora zakonna i ubóstwo, a przede wszystkim niechęć do manifestowania rzeczywistych lub urojonych zasług.

Znane nam obecnie plótna, to w więlsszości dary róznych osób z powodów czysto religijnych jak np. wszystkie obrazy w lzościele oleskim - pędzla Szymona Czechowicza, $z$ fundacji Seweryna Rzewuskiego ${ }^{1}$; już to $z$ powodów osobistych, jak legowana testamentem kolekcja obrazów malarza Piotra Bari ${ }^{2}$ lub portret ks. Józefa Putanowicza ${ }^{3}$ (Kraków nr 132), czy też portrety

1 J. Orańska (Szymon Czechowicz s. 146) podaje wylkaz obrazów w Olesku w liczble 13. $z$ wyjątkiem św. Antonıego los pozostałych plócien jest nieznany.

2 AKK, rkps HCC, I s. 80. - AKK, rkps 46: Sepulti in ecclesia nostra saeculares s. 5. ... S. C 1 a m pi: Viagg1o in Polonia. Firenze 1831 s. 135. - S. C 1 a $\mathrm{m}$ p i: Bibliografia critiea. T. 2. Firenze 1839 s. 245. - R a s t a w 1 e c k 1 : Slownik malarzów polskich, I 48. - Th 1 e me u. B e cker, II 496. - F Ko pe r a: Malarstwo XVII wieku. W: Polska jej dzieje $\imath$ kultura od czasów najalawnzejszych do chwili obecnej. T. 2. Warszawa 1927 s. 439. - B é né z $1 \mathrm{t}, \mathrm{I} 400$. Wyliczone leksykony zajmują sıę postacıą Piotra Barı bardzo ogólnıe, opierając sie głównle na tekścıe epitafium malarza w kościele kapucyńskim w Krakowie. Nieco więcel wıadomoścı o nım dostarcza kronika kapucynów krakowskich. Zgodnıe z jej przekazern artysta zmarı 18 sierpnia $1743 \mathrm{r}$. w klasztorze kapucyńskım, do którego przenıósł sı̨ 13 czerwea tegoz rolku ze wszystkımı swoimı ruchomościamı. Tak ojcowıe jak a bracıa troskliwie pielęgnowali chorego, który nalezał do wybitnych dobroczyńców klasztoru. Ofiarował bowiem w testamencie pewną ilość obrazów klasztorow. Miały być one sprzedane a dochód przeznaczony na remont 1 konserwację konwentu. Na wykonawców testamentu zostali wybran. Józef Fesstermantel i Jan Jerzy Sonner (Sohner). Dlatego ne odpowıada rzeczywistoścı twierdzenie, ze obrazy pędzla Barı znajdują się w koścıle kapucynów krakowskich. (Por, HCC, I 30: „D[omi]nus Parı, famosus pictor, obiit in nostro conventu et sepultus in cripta fratrum". "Die 18va augusti obiit in D[omi]no in hoc nostro conventu D[omi]nus Petrus Parı, famosus pictor, qui semper nobis affectus in lunio se ad nostrum contulit conventum, una cum mobilibus suss; paulo post infirmitate gravi correptus, post sex septimanas morbi patienter tolerati, in assistentia platr]is guardianı, quaem sibi in con- 
kilku kanoników krakowskich. Poza tym w prowincji OO. Kapucynów dawniej galicyjskiej a obecnie krakowskie j kilku zakonników, amatorów-malarzy, $z$ zapałem oddawało się $w$ wolnych chwilach sztuce malarskiej. Pozostawili

fessarıum elegit, et praesentia patrum et fratrum conventus vitam finivit. Sepultura elus fuit 20 currentis [augusti] cum funeralibus sub quibus 100 missae pro anma eius absolutae. Cadaver elus depositum in cripta fratrum. Vere msignis fuit stante vita noster benefactor, tum pro Domo Lauretana, tum pro sarta tectis conventus legando non paucas imagines maloris considerationis, ut his divenditis pecunia pro reparationibus ac necessitatibus conventus expendatur").

Obrazy nie zostały jednak sprzedane $w$ całoścl, skoro kronika pod r. 1747 podaje, ze trzy obrazy legowane klasztorowi przez Piotra Bari, zostaly przekazane pijarom krakowskim w zamian za 3.500 stypendiów mszalnych, które kapucynı krakowscy odesłali do odprawienıa frowincji kapucynów czeskich. Pienıądze stąd uzyskane obrócono na wybudowanıe nowej wiezyczkı przy kaplicy Loretańskıej. (Por. HCC, I 92: „Turrıs antiqua in Lauretana Domo, ob defectum firmioris fundamenti, unnixa trabibus tecti, cum semper minaretur perıculum tecti et fornicis ambitus Lauretanı, conclusum erat a fabris lignaris, ut omnino alia extruatur. Pro hac igitur de novo extruenda turri, cum alii deficerent modi, ex relictis imaginibus a ple defuncto Barı plctore, datae sunt tres R.R.P. Platrilbus Piaristis pro quibus susceperunt missas 3.500. Stipendia autem pro iís missis applicanda pro dicta fabrica missa sunt $a b$ A. R. P[at]re Pr[o]v[inci]ali Provinciae nostrae Boemıe").

w naszych poszukıwaniach udało sıe nam dotrzeć, zdaje się po raz pierwszy, do testamentu artysty. Znajduje sie on $w$ Wojewódzkim Archiwum Państwowym w Krakowie (ul. Sienna), w rękopısıe nr 478 pt. Consularıa cracoviensia, pod r. 1743, na s. 2712-2713.

$\mathrm{Na}$ podstawie odnalezıonego testamentu, nalezy najpierw zakwestionować nazwisko artysty. Kronika kapucyńska nazywa go raz Parı drug1 raz Barı. Testament natomiast nıe zna nazwıska Bari, ale przytacza nasteppujace warıanty nazwiska: Parr, Parrı, Paris.

Testament został sporzadzony 13 lipca $1743 \mathrm{r}$., kodycyl w spraw1e ruchomośc1 pozostawionych $w$ Warszawie dodano 3 sierpnia, a upowaznienie dla egzekutorów testamentu podpisano 17 lipca. Tegoz samego roku, dnia 23 sierpnia, dolsument zostal wpisany do krakowskich ksıag miejskich.

Nalezy zaznaczyć, ze urzędnik wpısujący dokument nie znał anı języka nıemıeckiego anı tym bardzıej gotyku, w którym zostal sporządzony oryginal testamentu. Dlatego dzjśs trudno odczytać poprawnie tekst, zachowany zresztą bardzo dobrze. Trzeba nieraz zastosować swoistą metode polegającą na zastąpıenıu wyrazów bezsensownych pojęcıamı domyślnymı. W ten sposób da sıę uchwycıc sens ostatnıej woli zmarłego malarza. Zwlaszcza $w$ konfrontacji z kroniką kapucyíską dalo sıę ustalić te partie rękopısu, które odnoszą sıę do kapucynów. I tak testator poleca egzekutorom, azeby sprzedali następujące plótna. 1) wlelk1 krucyfiks, 2) welkı obraz Wieczerzy Pańskicj, 3) wielkı obraz Narodzenıa Pańskıego, 4) 12 apostołów wielkości naturalnej, 5) św. Franciszek Ksawery 1 (i) pewną ilość pejzazy.

Płótna te nalezy natychmiast sprzedać, a dochód przeznaczyć na remont kaplicy Loretańskıej, koścıla 1 klasztoru. Pod konlec testamentu artysta zazmacza, ze zawsze pragnąl i taka jest jego ostatııa wola, azeby spocząc po śmıercı w podzıemiach koścıła kapucynów, o ile na to zasługuje.

Poza tym malarz zapisał p. Lendlein 30 obrazów w oryginalach 1 kopiach a wśród nich Sad Ostateczny na desce bukowed, Ecce Homo 1 Matke Boska oraz portret króla. Obrazy te zlecił wysłać natychmıst do Warszawy, na utrzymane tej pani. Kilku mnym osobom przekazał obrazy I książkı. W kodyeylu z 3 sıerpnı polecił, po uregulowanıı długów a wierzytelnoścı w warszawie, wszystkıe rzeczy warszawskıe dolączyć do krakowskıch 1 zuzytkowá na ibogich, chorych w szpitalu I na koścı́ł kapucynów. I tu p. Lendlein otrzymała portret Karola VI I inne legaty.

Na końcu wpısu testamentarnego znajduje sıę pełnomocnıctwo dla egzekutorów, równıez w języku niemıekım. Artysta, który posługuje sıę wspomnıanym językıem, otacza sıę przyjacı́́łmı Niemcamı, przyjaźnı sıę z kapucynaml, którzy od r. 1738 znajduja slę pod opleka kapucynów czeskich, bardzo juz zgermanizowanych, me moze być wlochem, fak chce Ciampi. Jeden z najstarszych nekrologów kapucynów polskich nazywa go ,germanus" (AKK, rkps 21. Felices patres et fratres peregrını, z r. 1750 k. 28). Przelsaz ten pochodz1 z czasów bliskich zycıa Plotra Bar 1 chyba definitywnie powınıen rozstrzygnąc problem przynaleznoścı narodowej tego znanego malasza.

3 AKK, rkps HCC, I s. 216-218. - AKK, rkps 46. Sepulti in ecclesia nostra seculares 5. 8. 
oni liczne płótna, szokujące nieraz szoim prymitywem, jak np. o. Florian Janocha (Kraków) i o. Józef Krzysikiewicz (Krosno, Sędziszów). Do tej kategorii oczywiście zaliczyć nie mozna o. Efrema Klawittera, artysty, malarza i rzeźbiarza o renomowanej europejskiej sławie. Pracował poza granicami kraju (Włochy, Belgia, Hiszpania), ale i u nas pozostawił swoje dzieła, jak np. zniszczone przez okupanta niemıeckiego płaskorzeźby $w$ katedrze gnieźnieńskiej ", sarkofag arcybpa Floriana Stablewskiego, dwıe płaskorzeźby w kościele parafialnym w Smogulcu, siedem witraży $w$ kościele parafialnym św. Józefa w Inowrocławiu ${ }^{5}$, św. Franciszka wśród ubogich w kościele parafialnym we Lwowie-Zamarstynowie ", portret kardynała Augusta Hlonda ', jak równiez kilka prac w klasztorze OO. Kapucynów w Krakowıe. Dzisiaj juź trudno ustalić proweniencję wielu płócien, zwłaszcza że kroniki klasztorne nie zawsze prowadzono systematycznie a archiwa nie zachowaly się $\mathrm{w}$ komplecie.

Duze wraźenie wywierały takze sztychy błogosławionych i świętych kapucynów na korytarzach klasztornych. Przypominały zakonnikom i gościom, aak duchownym jak i świeckim, o róznych drogach prowadzących do chrześciłańskiej doskonałości. Równiez plastyczne przedstawienie historii zakonu, prowincji czy klasztoru spotykało się z duzym uznaniem ze strony zainteresowanych osób. W tym to celu władze zakonne zamawiały u rytowników portrety sławnych zakonników, które później m. in. polscy kapucyni umieszczali na drewnianych tablicach. Tak powstały pod koniec XVII i w I połowie XVIII w. barokowe miedzioryty świętych i świątobliwych zakonników, na litórych przedstawiono ważne wydarzenia $\mathrm{z}$ ich zycia oraz laski otrzymane za ich pośrednictwem. Analiza treściowa biogramów umieszczonych pod każdym sztychem wskazuje na Hiszpanię i Włochy, skąd prawdopodobnie obrazy te rozeszły się po Europie. U nas zachowały się one prawdopodobnie tylko w klasztorze sędziszowskim (nr 89_..92).

W II połowie XVIII w. powstała w Rzymie seria sztychów przedstawiająca generałów zakonu, kardynałów, biskupów i arcybiskupów, kaznodziejów apostolskich oraz świętych i błogosławionych. Sztychy te sprowadził do Kraju o. Szymon Sikorski i porozsyłał do różnych klasztorów ${ }^{8}$. Po raz drugi serię tę, oczywiście uzupełnioną, wydała Kuria Generalna Zakonu OO. Kapucynów w Rzymie w r. $1914^{\circ}$. Ten sam urząd wzbogaca nadal pierwszą serię aktualnymi portretami. Sztychy powyższe wykonano techniką miedziorytniczą, posługując się $\mathrm{m}$. in. kliszami z XVIII i XIX w. Tablice ze sztychami zachowały się w klasztorach krakowskim, krośnieńskim i sędziszowskim.

Idąc za przykladem Rzymu, poszczególne prowincje zakonne na własna rękę opracowały swoją historię metoda wizualną na tablicach, nieraz bogato zdobionych. W prowincji polskiej, niestrudzony o. Szymon Sikorski, graficznie przedstawił wykazy generałów, prowincjałów, definitorów, gwardianów, ży-

4 W r. 1935 wybito pamiątkowy mcdal w celu uczczenıa jego zaslug polozonych dla ozdobıenıa katedry.

5 List H. 1 J. Klawitterowien, sióstr o. Efrema, z 8 I 1964 do autora inwentarza.

6 AKZ, rkps: Kronika Klasztoru OO. Kapucynów. Lwów na Zamarstynowle. Od roku panskiego 1904 s. 230.

7 Reprodukcje portretu spotyka sıę powszechııe na terenıe archidiecezji gnıeźnıeńskıej i. poznańskiej.

8 APK, rkps nr 165. O. Z. G or li ckl. Notatk1, III s. 284.

9 Lex, cap. szp. 792-793. 
jących i zmarłych zakonników, wraz z dołączeniem krótkiej historii prowincji ${ }^{10}$. Katalogi przyjęły $\mathrm{z}$ wielką wdzięcznością poszczególne konwenty. Zachowały się one prawdopodobnie tylko w Nowym Mieście i Krakowie, w ostatnim miejscu w stanie godnym pożałowania.

W porównaniu z obrazami obiekty rzeźbiarskie reprezentowane są w niewielkiej ilości, przeważnie w klasztorze krakowskim. Na uwage zasługuje o. Franciszek z Pescji, Giovan Pietro Marchi, który wykonał pierwsze rzeźby - Chrystusa Ukrzyżowanego w chórze zakonnym, krzyż ołtarzowy z kości słoniowej i statuę św. Feliksa z Cantalice ${ }^{11}$. Przypuszczalnie spod jego dłuta wyszła słynąca łaskami statua N. M. P.'Loretańskiej; ma ona bowiem wiele cech wspólnych z zagnionym św. Feliksem. O. Florian Janocha pozostawił swoje rzeźby w Rozwadowie i okolicy. W klasztorze krakowskim na uwagę zasługuje statua N. Marii P. zwana Tułaczką, św. Józef - dłuta T. Błotnickiego oraz stojąca do r. 1941 u wylotu ul. Kapucyńskiej statua N. M. P. Easkawej, która posiada poza sobą długą historię.

\section{Poniesione straty}

Trudno dziś ustalić dokładnie poniesione straty $w$ zbiorach sztuki klasztorów kapucyńskich, tym bardziej, że inwentarze kilku z nich (Lwów ${ }^{11 a}$, Lwów - Zamarstynów, Kutkorz, Mariampol ${ }^{11 b}$ ) nie zachowały się a te, które ocalały, opisują poszczególne obiekty tak lakonicznie i ogólnie, iż brak wszelkiej podstawy do rzeczowej identyfikacji. Dlatego na tym miejscu podajemy tylko niektóre zaginione obiekty sztuki sakralnej i świeckiej.

$\mathrm{Klasz}$ tor w Krakowie. Zaginęly portrety: ks. J. Eopackiego, kanonika krakowskiego, króla Stanisława Augusta Poniatowskiego, biskupów krakowskich Konstantego Felicjana Szaniawskiego i Jana Pawła Woronicza, Laskiewicza oraz Michała Stachowicza - "sławnego artysty malarza" 1". Przed r. 1939 statuy św. Wawrzyńca i św. Szczepana przekazano do Ogrójca, na cmentarzu przy kościele Bożego Ciała, dla celów kultu ${ }^{12}$. Wielki i bardzo cenny obraz św. Franciszka Ksawerego ${ }^{14}$ (zapewne XVII w.) przekazali przełożeni klasztoru, przy okazji remontu budynku klasztornego po drugiej wojnie światowej, do zbiorów kościoła Mariackiego. Ten sam los spotkał dwa

if APK, rkps nr 165: O. Z. Gor $11 \mathrm{ckl}$ : Notatki, III s. 284.

11 AKK, rkps HCC, I s. 31. - APK, rkps - O. P. K o c ha ńs k 1. Kościół zwiastowanıa s. 57. - O. W. N ow a k ow ski: Pamiątka s. 25. - O. K. G a d a c z: Inwentarz Archiwum s. 108.

11a P. B Ohdzie w $1 \mathrm{cz}$ : Korespondencja artystyczna Elżbiety Sienıawskiej z lat 1700$1729 \mathrm{w}$ zbiorach Czartoryskich w Krakowie. (Towarzystwo Naukowe Katolickiego Unıwersytetu Lubelskięgo. Rozprawy Wydzatu Historyczno-Filologicznego 30). Lublin 1964 s. $158,298$. Autorem obrazów Porcjunkuli, św. Antonıego 1 św. Rocha byl malarz włoski Altomonte. Informacje powyzszą uzupełnıa rkps $\mathrm{nr} 35$ Bibl. Un. Warsz. - Annales prov. Polonae (s. 139-140). Podaje on następujący wykaz obrazów "celeberrimi cuiuspiam pıctoris": w wielkım ołtarzu były obrazy Niepokalanego Poczęcra NMP, św. Stanısława bıskupa i św. Elżbiety Węgrerskiej; w bocznych, od strony Ewangelti - Porcjunkuli 1 św. Klary, od strony Lekcji - sw. Antoniego I św. Rocha.

11b W kościele kapucyńskım w Mariampolu znajoowały się następujące obrazy: w wielkım ołtarzu - św. Michała; w prawej nawle - dwa oltarze z obrazami Pana Jezusa w Ogrójcu a Matkı Bozej; w lewej - dwa oltarze z obrazamı św. Klary i św. Józefa; nad amboną wisiał obraz św. Marii Magdaleny (O. K. Ga dacz OFM Cap: Kapucyni w Galicji 1781-1810, rkps w posiadaniu autora).

12 AKK, rkps 38: Inwentarz z r. 1839 k. 6v, 9. - AKK, rkps 39: Inwentarz z r. 1821 k. $81 \mathrm{v}$.

13 AKK, rkps 38: Inwentarz z r. $1839 \mathrm{k}$. 7. Jezusa.

14 AKK, rkps 40: Inwentarz z r. 1875 s. 144. Znajdował się wtedy w kaplicy Pana 
wielkie olejne plótna wiszące na korytarzu parterowym obok refektarza. Dawno już zaginał obraz św. Eucji ${ }^{10}$. Po r. 1950 skradziono z korytarza parterowego obraz św. Antoniego, pędzla Piotra Dandiniego, będacego kopią obrazu z kościoła kapucyńskiego w Mantui ${ }^{10}$. Zaginął takze „Chór Kapucynów” " wdopodobnie kopia Vincenzo Chialli z I połowy XIX w. Chialli z zamiłowaniem odtwarzal sceny z zycia kapucynów ${ }^{18}$. Nieznane sa losy ,arbor religionis" czyli drzewa genealogicznego zakonu franciszkańskiego. Zaginęly tablice do historii kapucynów: tabela zakonu Kapucynów św. Franciszka, „kopersztychy ojców i braci" (przypuszczalnie takie same, jakie ma Sędziszów pod nr 89-92), katalog ojców i braci, wykaz przełożonych ${ }^{19}$. Nie wiadomo dziś, które płótna wyszły spod pędzla Mikołaja Janockiego, a które powinny znajdować się w klasztorze krakowskim ${ }^{20}$.

$\mathrm{K}$ lasztor w Krośnie. Zaginął jeden z ważnych zabytków klasztornych, a mianowicie portret o. Innocentego Bartha, budowniczego klasztoru i kościoła. Wisiał on $\mathrm{w}$ refektarzu a następnie $\mathrm{w}$ kościele, nad drzwiami zakrystii $^{21}$. Nie istnieje również portret o. Józefa Krzysikiewicza, wykonany furtivo modo przez malarza Pawła Bogdańskiego w r. $1854^{22}$. Nie zachowała się część plócien pędzla tegoż o. Józefa z r. 1858 i obrazy przedstawiające tajemnice Męki Pańskiej, a przeznaczone na zasłony do ołtarzy na okres wielkiego postu, z r. $1864^{23}$. Nie ma obecnie wielkiego obrazu Wieczerzy Pańskiej z r. $1829^{24}$, ani obrazu bł. Jana z Dukli z r. $1821^{25}$. Nie wyjaśniona jest także sprawa obrazów Papużyńskiego w klasztorze ${ }^{26}$.

Klasztor w Kutkorzu. Z obrazów ocalał jedynie cudowny obraz N. M.P. Śnieżnej przewieziony przez parafian w r. 1944 do Sędziszowa (nr 18). Na miejscu pozostały: płótno przedstawiające otrzymane łaski za pośrednictwem cudownej Madonny, dzieło o. Floriana Janochy; olejny portret wyobrażający króla Ludwika XIV w wieku chłopięcym, w pozycji stojącej, z prawą ręką złożoną na koronie. Być może, że dzieło to znalazło się w klasztorze w czasie pierwszej wojny światowej, kiedy to spłoną miejscowy palac. W refektarzu pozostał portret Jerzego Eacczyńskiego i jego żony, fundatorów klasztoru. $\mathrm{Na}$ korytarzu klasztornym wisiał portret Jana III Sobieskiego i kilku lwowskich kanoników katedralnych. Dawny obraz z wielkiego ołtarza, przedstawiający Matkę Boską, pozostał w zakrystii. Tam też znajdowały się dwa medaliony na blasze miedzianej z portretami Sobie-

15 AKK, rkps HCC, I s. 8. Dar Dionizego Mecottił'ego, wykonany w Luce w r. 1699. Obarz ten był $w$ wielkiej czcı u ludu az do r. 1790. - APK, rkps - O. K. Ga d a c z: Historia klasztoru s. 11, 22.

16 AKK, rkps HCC, I s. 8. - APK, rkps - O. K. G a d a c z: Historia klasztoru s. 11, 12. - APK, rkps - O. P. K o c ha h $\mathrm{k}$ i: Kościól Zwiastowania s. 20, 22. - S. Ci a mpl: Notizie s. 95-108. - M. S k r u d l k: Królowa Korony Polskiej s. 291, 294, 303.

17 AKK, rkps 38: Inwentarz z r. 1839 k. 9.

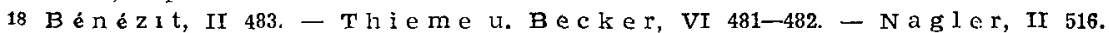

19 AKK, rkps 38: Inwentarz z r. $1839 \mathrm{k} .8-8 \mathrm{v}$.

20 R a sta w i e cki: Słownik malarzów polskich, I 206. - J. B r odow ski: Myśl do ustanowienıa Towarzystwa Sztuk Pięknych, Malarstwa, Rzeźbiarstwa, Budownictwa. Pszcz. krak. R. 4: 1822 t. 1 s. 19. - Janowslsi Michał. W: Podreczna encyklopedia koscielna [pod red.]

ks. Z. Chetmickiego. T. 17/18. Warszawa 1909 s. 390-391.

21 Ks. W. S la r n al: Kościół i klasztor s. 14-15.

22 AKKR, rkps CCC, II s. 51.

23 AKKR, rkps CCC, II s. 89.

24 AKKR, rkps 3: Inwentarz z r. 1829 k. 150.

25 AKKR, rkps 3: Inwentarz z r. 1821 k. 145.

26 R a ta wieckl. Słownik malarzów polskich, II 320-321. 
skich. Zostały one zdjęte z rodzinnego grobowca Sobieskich w Żółkwi i przesłane Kapucynom w Kutkorzu ${ }^{27}$.

Klasztor we Lwowie-Zamarstynowie. Na miejscu pozostak w wielkim ołtarzu obraz św. Franciszka wśród ubogich, pędzla o. Efrema Klawittera, wykonany bezinteresownie przez artystę w r. $1936^{28}$. Prawdopodobnie pozostał tam również obraz M. B. Anielskiej, pędzla Stanisława Bergmana z Krosna ${ }^{29}$. Obraz św. Teresy od Dzieciątka Jezus, pędzla Wł. Barwickiego, został przewieziony do Krakowa i tu zaginął. Obraz św. Józefa znajduje się obecnie w Rozwadowie (nr 18). Dwie rzeźby z wielkiego ołtarza św. Wojciech i św. Stanisław (z pracowni Jana Wojtowicza w Przemyślanach) mieszczą sie obecnie w wielkim oltarzu w Tenczynie.

Klasztor w Olesku. Ostatni gwardian oleski, o. Felicjan Piskor, opuścil klasztor 6 czerwca 1944 r. W lronice klasztornej wtedy zapisal: „Rządź Ty Panie Boże, bo gwardian nie może”. Wcześniej jeszcze, bo 25 maja br. Filip Kubacki przewiózł cudowny obraz św. Antoniego do Sędziszowa ${ }^{30}$. 12 innych obrazów oltarzowych pozostało na miejscu. Pod koniec r. 1944 o. Florian Nestorowski zabral obrazy oltarzowe z bocznych oltarzy. Po nim przyjechał o. Zygmunt Nestorowski z Huciska Oleskiego, brat o. Floriana, i zabrał obrazy: św. Józefa z wielkiego ołtarza, św. Wawrzyńca z Brindisi na zasuwie ołtarza św. Antoniego i wszystkie obrazy ze zwieńczeń ołtarzy ${ }^{31}$. Obraz św. Wawrzyńca znajduje się obecnie w Krakowie (nr 169). Losy pozostałych płócien Szymona Czechowicza sa nieznane.

$\mathrm{Na}$ podștawie inwentarza tegoz klasztoru z r. 1850 można wnioskować, że zaginęly obrazy: św. Sebastiana, św. Katarzyny, św. Tekli, św. Jana Nepomucena, Wniebowzięcia N. M. P., św. Franciszka i św. Bonawentury. Z portretów ocalal fundatora klasztoru Seweryna Rzewuskiego (Kraków nr 224), znajdujący się niegdyś w chórze zakonnym, u stóp Chrystusa Ukrzyżowanego, ale przepadl portret Waclawa Rzewuskiego, brata Seweryna. Na miejscu pozostały lub zostały skradzione portrety: papieża Benedykta XIV, cesarzy Ferynànda i Józefa (II ?), karynałów-kapucynów: Anzelma Marzati († 1607), Antoniego Barberini ( $\dagger$ 1646) i Franciszka Casini $(\dagger 1719)^{32}$. Na cmentarzu kościelnym pozostały rzeźby: Matki Bozej na postumencie (w środku) oraz św. Franciszka i Antoniego, wykonane w pełnym kamieniu (z boku) ${ }^{33}$

Klasztor $w$ Rozw a d o w i e. Inwentarz z $r$. 1835 wylicza 37 obrazów w kościele $i$ zakrystii, a w klasztorze ok. 31, z wyjątkiem papierowej stacji Drogi Krzyżowej. Dzisiaj brak następujących obrazów: ołtarzowego św. Bar-

27 Informacja o. Władysława zająca z r. 1964. Poza tym przed kościołem pozostały dwa epitafia na kamiennych nagrobkach, Jeden Józefa Łączyńskiego, zm. 19 maja 1800 r. 1 drugi Julii z Raciborowskich Komorowskıej, zm. 31 maja 1828 r. W progu koścıoła znajdowal się kamień z napısem: „D.O.M. Wielm. Maryanna Konstancya z OIszewskıch Easka podczaszyna Podolska, umarla d. 13 Maja r. 1786; prosı o Zdrowaś Marya" (Por. ks. P o d olsk 1. Kutkorz. Przyj. dom. R. 4: 1854 nr 9 s. 66. - Slownik geograficzny Królestwa Polskiego i lunych krajów słowiańskich. T. 4. Warszawa 1883 s. 954: Kutkorz). Obrazy z bocznych oltarzy św. Franciszka 1 ,Ecce Homo", pędzla Marcina Jabłońskıego z r. 1852, pozostaly na miejscu (Por.: O. K. Ga d a c z: Inwentarz Archiwum s. 154).

28 Por. przyp. 6.

29 AKK, rkps $\mathrm{HCC}$, III s. 318 .

so AKO, rkps - Kronika klasztoru OO. Kapucynów w Olesku od roku 1933, III s. 88.

31 Wywiad $z$ o. Zygmuntem Nestorowskim przeprowadzony w grudniu 1963 r. W Rozwadowie.

32 AKO, rkps - Akta rózne. T. VIII: $1788-1923$ - Inwentarz z r. 1850 k. $79 \mathrm{v}-\mathbf{3 0}$.

33 AKo, rkps - Akta rózne. T. VIII: Inwentarz z r. 1826 k. 58. 
bary, św. Kazimierza, św. Eustachego, obrazu z napisem „Vanitas vanitatum”, portretów papieży Bonifacego i Jana $I^{34}$, zasłon na ołtarze $w$ okresie wielkiego postu, wykonanych przez malarza Antoniego Zacharskiego z Krosna, a mianowicie: Męki Pana Jezusa, Chrystusa w Getsemani, Chrystusa u Piłata, Chrystusa ubiczowanego i cierniem ukoronowanego. Brak portretów cesarza Franciszka I i jego zony (1825) oraz 214 sztychów przedstawiających kapucynów, a takze katalogu przełozonych konwentu ${ }^{35}$.

Klasztor w S ę d z is z o wi e. Inwentarz z r. 1826 podaje, ze w refektarzu znajdowalo się 19 olejnych obrazów a na korytarzach klasztornych 100 wizerunków, oczywiściee sztychów, przedstawiających kapucynów. Były też stacje Drogi Krzyzowej, których dziś brak. Zginął prawdopodobnie obraz ołtarzowy św. Franciszka ${ }^{36}$.

\section{Epitafia i inskrypje}

Kościół lkapucyński w Krakowie stał się prawdziwie przybytkiem rodziny Dembińskich, związanych węzłami krwi z fundatorem Albrechtem Dembińskim († 1720). Tu najczęściej zawierali oni zwiąki małzeńskie i tu grzebali swoich najblizszych $w$ krypcie fundatorskiej lub w kalakumbach kaplicy Loretańskiej. Stąd liczne epitafia tej rodziny na ścianach kościoła ${ }^{37}$. Zwyczaj grzebania zmarłych w kościołach został zabroniony przez Senat Wolnego Miasta Krakowa ok. 1842 r. Zezwolenia udzielano jedynie pod warunkiem, że zwłoki zostaną zabalsamowane. Odtąd tak zakonników jak i świeckich grzebano na cmentarzu publicznym. Ale epitafia nadal były w uzyciu i stały się, z biegiem lat, ozdobą i osobliwością ubogiej zresztą świątyni.

Spotykamy tu pomniki bohaterów narodowych: konfederatów barskich $(\dagger$ 1768), Tadeusza Kościuszki z r. 1896, gen. Józefa Wodzickiego ( $\dagger$ 1794), pulk. Piotra Swiderskiego († 1828), Władysława Rawicza ( $\dagger$ 1863), Romualda Traugutta († 1864) i gen. Tadeusza Jordan Rozwadowskiego ( $\dagger$ 1928); profesorów U. J.: Józefa Łepkowskiego ( $†$ 1894), Seweryna Hammera († 1955), Ludwika Piotrowicza $(\dagger 1957)$ i Juliusza Kleinera († 1957); prezydenta $\mathrm{m}$. Krakowa Filipa Nereusza Lichockiego; malarza Piotra Bari († 1743); architekta Szczepana Humberta († 1829). Wyróżniają się wśród nich barokowy nagrobek Albrechta Dembińskiego, rokokowy P. Bari, empirowy J. Wodzickiego, klasycystyczny Alojzy Liehmann $(\dagger$ 1837) oraz spiżowe popiersie T. Rozwadowskiego. Kilka epitafiów usunięto ze ścian kościoła z okazji remontu. Pozostałe kościoły kapucyńskie epitafiów prawie nie posiadaja.

\section{Klisze drukarskie}

Są to przeważnie pozostałości niekompletne po pisarzach kapucyńskich, o. Wacławie Nowakowskim († 1903) i o. Florianie Janosze ( $\dagger$ 1921). Z chwila uruchomienia w r. 1936 w Krakowie własnej drukarni i wydawnictwa, klisze te zostały włączone przez o. mgr Alojzego Wojnara, redaktora czasopisma Pokój $\imath$ Dobro, do kolekcji redakcji. Wzbogacono ja następnie kliszami Kole-

\footnotetext{
34 AKR, rkps - Inwentarze kościola l klasztoru 1785-1835. Inwentarz z r. 1835 k. 42v, $50 \mathrm{v}, \quad 55 \mathrm{v}, 64 \mathrm{v}-65$.

35 AKR, rkps HCR, I s. 166, - AKR, rkps - Inwentarze kościoła I klasztoru 1785-1835: Inwentarz z r. $1824 \mathrm{k}$. $6 \mathrm{v}$; Inwentarz z r. $1825 \mathrm{k}$. 16; Inwentarz z r. $1835 \mathrm{k} .64 \mathrm{v}$.

30 AKS, rkps - Inwentarz z r, 1827 s. 18, 66.

37 AKK, rkps 43-44, 46.
} 
gjum Serafickiego OO. Kapucynów w Rozwadowie. Zbiory powiększały się stopniowo. W r. 1939 Niemcy skonfiskowali drukarnię i zagarnęli jej wyposazenie. Z ocalałych klisz wiele uległo zniszczeniu, tak wskutek wpływów atmosferycznych jak i z braku odpowiedniej konserwacji.

Tak więc na przestrzeni blisko trzech stuleci klasztory kapucyńskie stały się samoistnymi galeriami sztuki sakralnej i świeckiej. Obok średniowiecznej Madonny (Kraków nr 260) widzimy ruską ikonę (Kraków nr 243), rzymskie miedzioryty i japońskie drzeworyty. $\mathrm{Z}$ bardziej znanych malarzy spotykamy: Anioła Bronzino, Piotra Dandini, J. Ch. Lampiego; z polskich Szymona Czechowicza, Eukasza Orłowskiego, Michała Stachowicza, o. Efrema Klawittera; z rzeźbiarzy: o. Franciszka z Pescji, T. Błotnickiego i K. Laszczkę. W sumie przeszło 170 artystów, malarzy, rzeźbiarzy i sztycharzy pozostawiło swoje dzieła w klasztorach kapucyńskich. Gotyk, renesans, barok, rokoko, klasycyzm i sztuka wspólczesna sąsiadują z sobą, tworząc żywą i barwną ilustrację do historii sztuki, Kościoła, zakonu i jego prowincji.

\section{Metoda opracowania}

Sposób inwentaryzacji zabytków sztuki określa instrukcja wydana przez Państwowy Instytut Sztuki w Warszawie (Zasady polskiego inwentarza zabytków sztuki. Warszawa 1948). Z tego jednak względu, że obecny inwentarz ma opisać całość malarstwa sztalugowego, grafikę i snycerstwo, bez względu na zabytkowy charakter inwentaryzowanych obiektów, należało przyjąć zasady nie zawsze zgodne $\mathrm{z}$ w. w. instrukcją.

Przede wszystkim inwentarz obejmuje obiekty wiszące, stojące lub wmurowane $\mathrm{w}$ ściany kościołów i klasztorów kapucyńskich. Przedmioty te opisuje poczynając od cmentarza kościelnego, kruchty, kościoła, kaplic, chóru zakonnego, zakrystii, parteru klasztornego, pierwszego względnie drugiego piętra. Najpierw podaje się wykaz obiektów inwentaryzacyjnych kościoła i klasztoru krakowskiego, po nim - w porządku alfabetycznym następują inne klasztory.

$\mathrm{Na}$ pierwszym miejscu opisano obrazy sztalugowe i grafikę, następnie rzeźby i plaskorzeźby, epitafia i klisze drukarskie. Wszystkie jednostki w powyższym podziale otrzymały oddzielna numerację cyframi arabskimi od jednego w zwyz.

Schemat opisu inwentaryzacyjnego w zakresie obiektów ruchomych został przejęty $z$ wymienionej instrukcji ( $\$ 6)$. Po numeracji podano więc temat przedstawienia, wymiary (dla obrazów, plaskorzeźb, epitafiów i klisz szerokość $X$ wysokość; dla rzeźb wysokość; dla krzyży i krucyfiksów wysokość korpusu i rozpiętość rąk; wymiary obrazów oltarzowych podano przeważnie w świetle ram; wymiary obrazów i rzeźb znajdujących się wysoko lub $\mathrm{w}$ zwieńczeniach oltarzy podano $\mathrm{w}$ przybliżeniu), materiał, technike, kompozycję całości, stan zachowania, sygnatury, styl, czas powstania oraz autora a w wyjątkowych wypadkach, przy obrazach zabytkowych i wartościowych, także przynależność do określonych szkół i kierunków. W szerokim zakresie została uwzględniona proweniencja i historia obiektów.

Kapucyńskie zbiory sztuki posiadają wiele obiektów bezwartościowych i bezstylowych. Przy opisie tych jednostek podano tylko ich elementy zasadnicze. 
Przy oznaczaniu prawej i lewej strony obiektu przyjęto orientacje od strony widza; przy opisie poszczególnej osoby (pod uwagę brano tylko ręce, nogi, perizonium) - orientację heraldyczną.

Pod tak zmodyfikowanym opisem podano dła każdego obiektu oddzielnie dokumentację archiwalno-bibliograficzną pod wspólnym tytułem: Bibliografia.

Ażeby niepotrzebnie nie mnożyć przypisów, pominięto cytowanie kopii inwentarzy znajdujących się w innych archiwach. I tak w opracowạniu zbiorów klasztoru krakowskiego pominięto Inwentarz temporaliów kościola i klasztoru XX. Kapucynów w Krakowie, rok 1821, znajdujący się w Wojewódzkim Archiwum Państwowym w Krakowie (ul. Sienna) oraz kopię tegoż, przechowywaną w Archiwum Metropolitalnym w Krakowie (hasło: OO. Kapucyni). Podobnie w opisie zbiorów sztuki klasztoru w Krośnie pominięto kopię inwentarza klasztoru z r. 1821, która znajduje się w Archiwum Diecezjalnym ob. łac. w Przemyślu (Krosno, rkps nr 1015), a w opracowaniu zbiorów konwentu w Rozwadowie - inwentarz tegoz klasztoru z r. 1825 (Tamże: Rozwadów, rkps nr 1530). Oryginały względnie kopie powyższych inwentarzy znajdują się bowiem w archiwach kapucyńskich i zostały w pelni wykorzystane. Należy jeszcze zaznaczyć, że autor nie dążył do pełnego zestawienia bibliografii.

$\mathrm{Na}$ końcu pracy zamieszczono indelss przedmiotów, osób i miejscowości.

\title{
I. ZBIORY SZTUKI KLASZTORU W KRAKOWIE
}

\section{OBRAZY SZTALUGOWE I GRAFIKA}

\author{
Kościól klasztorny
}

\section{1}

Zwiastosowanie N. Marii P., w wielkim ołtarzu, ok. 153,5 $\times 265 \mathrm{~cm}$, płótno, olej. Madonna $\mathrm{z}$ rękami złożonymi na kolanach, siedzi $\mathrm{z}$ prawej strony na gotyckim tronie z purpurowym zapleckiem i drewnianym baldachimem, lekko zwrócona w lewo, w stronę archanioła Gabriela. Wokoło postaci archaniola widoczne zlote promienıe. Pomiędzy nim a Marią klęcznik z czerwoną poduszką i księgą do modlitwy. Komnatę zaściela dywan z czarnoczerwonym deseniem. Sulknia Marii fioletoworóżowa, płaszcz błękitny z białą podszewką. Archanioł w żółtej sukni i zielonobiałym płaszczu, skrzydła w zielonoczerwonych tonach. Z lewej strony, w górze, Duch Św. w postaci gołębicy, w chmurze żóltego światła.

Zwiastowanie zostało skopiowane, na prośbę kapucynów krakowskich, ze średniowiecznego cudownego obrazu znajdującego się w kościele Serwitów pod wezwaniem Santa Maria Annunziata we Florencji. Kopia różni się od oryginału ścieśnieniem kompozycji, podylktowanym ograniczoną szerokością obrazu ołtarzowego w Krakowie. Z konieczności więc artysta pominąl wiele szczegółów oryginału. Róznica widoczna jest przede wszystkim pod względem techniki. Technika $\mathrm{z}$ okresu baroku nie wytrzymała konkurencji z techniką średniowiecza. Na skutek zmian chemicznych obraz stracił dawny typowy koloryt, ściemniał a farby olejne postradały pierwotna spoistość.

Obraz jest darem Kosmy III Medyceusza, wielkiego księcia Toskanii. 
Pośredniczył w otrzymaniu go baron de Bruno, przedstawiciel dworu florenckiego na koronację Augusta II. Malowal Pietro Dandini w r. 1701. Konserwację przeprowadził w r. 1820 malarz Dębowski a w r. 1917 Juliusz Krupski ze Lwowa.

Bibliogafia: AKK, rkps HCC, I s. 8 (mylnie podaje nazwisko artysty: Danaini). - AKK, rkps 38: Inwentarz z r. 1839 k. 4v. - AKK, rkps 39: Inwen$\operatorname{tarz} z$ r. 1821 k. 18, 63, 63v. - Inwentarz z r. 1858 k. 101. - Inwen$\operatorname{tarz}$ z r. 1871 k. 146v. - AKK, rkps 40: Inwentarz z r. 1875 s. 18. - APK, rkps - O. K. G a d a cz: Historia klasztoru s. 11, 12. - APK, rkps - O. P. Koch ański: Kościół Zwiastowania s. 55-57. - Bibl. Un. Warsz., rkps sygn. 35: Annales Provinciae Polonae k. 97. - P. H. Pruszcz: Klejnoty stolecznego miasta Krakowa. Kraków 1745 s. 170. - S. Ci a m pi: Notizie s. 98. - Tomasz Dolabella. Przyj. Ludu. R. 7: 1840 t. 1 s. 51 przyp. 3. - [A. K le czkowski] A.: Swięte pamiątki Krakowa. Kraków 1883 s. 409, 418.- O. W. Now a k ow s ki: Pamiątka s. 18. - M. Skr u d lik: Tomasz Dolabella, jego życie i dzieła. Ustęp z dziejów malarstwa XVII stulecia w Polsce. Rocz. krak. T. 16: 1914 s. 142, 159 przyp. 126. - M. Skrudlik: O klasztorze OO. Kapucynów w Krakowie. E. Chwalewik: Zbiory polskie. T. I s. 221. - M. Skrudlik: Królowa Korony Polskiej s. 293-294, 296-300. - M. Skrudlik: Zwiastowanie. Ilustr. Kur. codz. R. 22: $1931 \mathrm{nr}$ 82. - O. K. Ga d a c z: Inwentarz Archiwum s. 108.

\section{2}

Św. Józef, w zwieńczeniu wielkiego ołtarza, $104 \times 132 \mathrm{~cm}$, płótno olej. W owalu półpostać w postawie siedzącej, głowa pochylona nad Dzieciątkiem, w lewej ręce trzyma białą lilię. Kolorystyka szat żółtoniebieska. Tło obrazu niebieskie. Malował Franciszek Ignacy (?) Molitor w r. 1775 za cenę 5 dukatów (5 aureorunı).

Bibliografia: AKK, rkps HCC, I s. 169 (mylnie podaje nazwisko malarza: Militor). - AKK, rkps 38: Inwentarz z r. 1839 k. 4v. - AKK, rkps 39: Inwentarz $z$ r. $1821 \mathrm{k}, 18,63$. - Inwentarz z r. $1858 \mathrm{k} .101$ - - Inwentarz z r. 1871 k. 146v. - AKK, rkps 40: Inwentarz z r. 1875 s. 18. - APK, rkps - O. P. K och ańs ki: Kościół Zwiastowania s. 57. Tu również zachodzi pomyłka w podaniu nazwiska malarza z błędnym wymieniem strony 170 kroniki, - O. W. N ow akowski: Pamiątka s. 18. I tu brzmienie nazwiska malarza błędnie przytoczone za kroniką. - Rastawi e cki: Slownik malarzów polskich, III S. 338-339. Franciszek Ignacy Molitor zmarł w r. 1778 i on prawdopodobnie jest twórca obrazu; Jan Piotr Molitor umarł w r. 1756, a Piotr Franciszek malował jeszcze w r. 1765. - IV. Skrudlik: O klasztorze OO. Kapucynów w Krakowie. E. Chwalewik: Zbiory polskie. T. 1 s. 221.

\section{3}

Sw. Klara, na ścianie po prawej stronie wielkiego oltarza, $67 \times 106,5 \mathrm{~cm}$, płótno, olej. Swięta en face, z głową lekko przechyloną w lewo, w obu rękach trzyma renesansową monstancję, podniesiona na wysokości ramion z prawej strony obrazu. Ponad monstrancją dwa putta. Tło brązowoniebieskie. I pol. XVIII w. s. 57.

Bibliografia: APK, rkps - O. P. Kochański: Kościól Zwiastowania

\section{4}

Św. Franciszek, na ścianie po lewej stronie wielkiego ołtarza, $66 \times 107 \mathrm{~cm}$, płótno, olej. Święty w brązowym habicie kapucyńskim, z twarzą trzy czwarte w prawo, lewą dłonią wskazuje na ziemię, prawa z czaszką złożona na księdze. Ponad glowa unoszą się dwa putta. Tło obrazu brązowoniebieskie. I pol. XVIII w. s. 57 .

Bibliografia: APK, rkps - O. P. Kochański: Kościól Zwiastowania 
Sw. Fidelis z Sigmaringen, w nawie z prawej strony, na zasuwie oltarza N. M. Panny, $96,5 \times 171 \mathrm{~cm}$ w świetle ram, płótno, olej. W pozycji stojącej, en face, w kapturze na głowie, w brązowym habicie kapucyńskim. W praw,ej ręce wzniesionej $\mathrm{w}$ górę trzyma krzyż, lewa złożona na sercu. Ponad głową świętego $\mathrm{z}$ prawej strony wznosi się anioł $\mathrm{z}$ palmą męczeńska $\mathrm{w}$ prawej ręce i wiencem laurowym w lewej. Glowa świętego w aureoli świetlnej. Blask ten rozjaśnia górną część obrazu żółtym światłem. Pozostałe tło obrazu ciemnobrązowe. Kronika klasztoru krakowskiego pod rokiem 1747 wspomina, że z okazji uroczystości kanonizacyjnych św. Fidelisa, wybitny malarz z Pragi, Jerzy Neunstätter, wykonał pewne płótna wewnątrz i zewnątrz kościoła. Czy jednak obraz jest rzeczywiście jego dziełem - na to nie ma żadnych innych dowodów. I poł. XVIII w. Późnobarokowy. Obraz odnowił w r. 1938 br. Efrem Chmiel.

Bibliografia: AKK, rkps HCC, I s. 94. - AKK, rkps 38: Inwentarz z r. 1839 k. 4v. - AKK, rkps 39: Inwentarz z r. 1821 k. 18v, 64; Inwentarz z r. 1858 k. 101v; Inwentarz z r. 1871 k. 147v. - AKK, rkps 40: Inwentarz z r. 1875 s. 22. - APK, rkps - Br. E. Chmiel: Kronika s. 23. - APK, rkps O. P. Ko chański: Kościół Zwiastowania s. 58. - O. W. No wa k ow ski: Pamiątka s. 19.

\section{6}

Najświętsze Serce Jezusowe, na predelli ołtarza N. Marii P., $47 \times 56 \mathrm{~cm}$, płótno, olej. Popiersie Jezusa, en face, z głową lekko pochyloną, w niebieskiej szacie, z lewego ramienia opada purpurowy płaszcz. Obydwiema rękami wskazuje gorejące serce. Tło ciemnogranatowe. II poł. XIX w.

Bibliografia: AKK, rkps 40: Inwentarz $z$ r. 1875 s. 22. Na predelli do r. 1875 znajdował się obraz św Eukasza. W inwentarzu późniejsza ręka przekre.śliła obraz św. Łulkasza a umieściła pozycję "Serce P. Jezusa". APK, rkps O. P. K o chań s ki: Kościół Zwiastowania s. 59.

\section{7}

Sw. Stanisław ze Szczepanowa, w zwieńczeniu ołtarza N. Marii P., $41 \times 63 \mathrm{~cm} \mathrm{w}$ świetle ram, płótno, olej. Popiersie świętego, $\mathrm{z}$ twarzą trzy czwarte $w$ lewo, w bialej infule $i$ szatach biskupich. Dominujące kolory białoźółte. XVIII w.

Bibliog rafia: AKK, rkps 38: Inwentarz z r. 1839 k. 4v. - AKK, rkps 39: Inwentarz z r. $1821 \mathrm{k} .18 \mathrm{v}, 64$, Inwentarz $\mathrm{z}$ r. $1858 \mathrm{k} .101 \mathrm{v}$; Inwentarz z r. 1871 k. 147v. - AKK, rkps 40: Inwentarz z r. 1875 s. 22. - APK, rkps - O. P. Kochański: Kościół Zwiastowania s. 59.

\section{8}

Św. Józef z Leonessy, kapucyn, w nawie z lewej strony, na zasuwie oltarza św. Józefa, $97 \times 172 \mathrm{~cm}$ w świetle ram, płótno, olej. W sklepionej celi więziennej z zakratowanym okienkiem - święty w pozycji stojącej, z twarzą trzy czwarte $w$ prawo, $w$ brąowym habicie i kapucyńskim płaszczu, w prawej ręce trzyma krzyż, błogosławiąc więźnia siedzącego w kajdanach na kamiennej posadzce $\mathrm{i}$ wznoszạcego lewą rękę $\mathrm{z}$ błagalnym gestem w stronę świętego. Tło szare i jasnobrązowe. Sygn. z lewej u dołu: „A[ntoni] Gramatyka. $1870 \mathrm{r."}$

B i b li o grafia: AKK, rkps 39: Inwentarz z r. $1871 \mathrm{k}, 147$. - APK, rkps O. P. Kochań ski: Kościól Zwiastowania s. 59, - O. W. Now a k ow ski: Pamiątka s. 18. 
9

Matka Boska Częstochowska, na predelli ołtarza św. Józefa, $40 \times 49 \mathrm{~cm}$, obraz wytłaczany na blasze i pozłacany na ciennnym tle. II pol. XIX w.

Bibliografia: AKK, rkps 40: Inwentarz z r. 1875 s. 116. - APK, rkps O. P. K o c hań ski: Kościól Zwiastowania s. 60 .

10

Ŝw. Wojciech, biskup i męczennik, w zwieńczeniu ołtarza św. Józefa, $41 \times 63 \mathrm{~cm}$, płótno, olej. Popiersie świętego w czerwonej infule, z pastorałem w lewej ręce, w bialej szacie i czerwonej kapie. I poł. XVIII w.

Bibliografia: AKK, rkps 38: Inwentarz z r. $1839 \mathrm{k}$. 4v. - AKK, rkps 39: Inwentarz z r. 1821 k. 18, 63v; Inwentarz z r. 1858 k. 101; Inwentarz z r. 1871 k. 147. - AKK, rkps 40: Inwentarz z r. 1875 s. 20. - APK, rkps - O. P. K ochańs ki: Kościół Zwiastowania s. 60 .

\section{1}

Najświętsze Serce Marii, w kaplicy św. Franciszka na filarze, $86 \times 115 \mathrm{~cm}$, płótno, olej. N. Maria P. w pozycji frontalnej, stojącej, en face, w obłokach $\mathrm{z}$ chmur. W białej chustce i niebieskim płaszczu, prawą ręką wskazuje na ziemię, a lewą na gorejące Serce. Tło białoszare. Sygn.: „A[dolf] Hyła. 1945". Obraz kosztował $10.000 \mathrm{zk}$.

Bibliografia: AKK, rkps HCC, IV s. 367. - AKK, rkps HCC, IVa s. 20. APK, rkps - Br. E. Chmi el: Kronika s. 121. - APK, rkps - O. P. Koch a íski: Kościól Zwiastowania s. 20.

Sw. Franciszek z Asyżu, w ołtarzu św. Franciszlza, w pierwszej kaplicy $z$ prawej strony nawy, $105 \times 177,5 \mathrm{~cm}$, płótno, olej. W ciemnej niszy o gotyckim sklepieniu, na kamiennym postumencie, stoi święty w pozycji frontalnej, z kapturem na głowie, boso, z rękami wsuniętymi w rękawy habitu, w brązowym kapucyńskim habicie, $z$ bladą twarzą, lekko zwróconą $w$ prawą stronę. Ciemne tło obrazu rozjaśna nieco delikatny płomyk kaganka z lewej strony w górze. Kompozycja obrazu spokojna, zimno i chłód wieje od grobowca, ale uwage przykuwa twarz świętego, „która promienieje fosforycznym blaskiem". Dzieło to jest przykładem przeniany baroku w klasycyzm, który $w$ tym okresie rodzi się na nowo. Równocześnie ilustruje podanie związane $z$ odnalezieniem grobu świętego $w$ r. 1449. Sw. Franciszek został pochowany $w$ dolnym kościele asyskim, ale miejsce pochowania pozostało nieznane. W r. 1449 papież Mikołaj V rozkazał zburzyć jedno z wejść grobowych $i$ wówczas wszyscy obecni $z$ papiezem ujrzeli św. Franciszka w postawie stojącej. A tak niezwykły blask bił z jego oczu, iż wszystkim zdawało się, że to żywy święty stoi przed nimi. Sławni artyści ośmielili się przedstawić tę scenę. Jedni, jak La Hire w r. 1630, ograniczyli się do przedstawienia orszaku wchodzącego do podziemi, innym bardziej odpowiadała sama scena odnalezienia świętego. Do tych ostatnich należy również Czechowicz. Ale jego dzieło jest na wskroś oryginalne i przepiękne w swej kompozycji. Malowal Szymon Czechowicz w r. 1775, za cenę 26 dukatów.

B ib li o g r a i a: AKK, rkps HCC, I s, 169. - AKK, rkps 38: Inwentarz z r. $1839 \mathrm{k} .4 \mathrm{v}$. - AKK, rkps 39: Inwentarz z r. $1821 \mathrm{k} .18 \mathrm{v}, 64,64 \mathrm{v}$; Inwentarz z r. 1858 k. 102; Inwentarz z r. 1871 k. $147 \mathrm{v}$. - AKK, rkps 40: Inwentarz z r. 1875 s. 22. - APK, rkps - O. P. Ko chański: Kościól Zwiastowania s. 65, 66. O. W. Now a kowski: Pamiątka s. 19. - M. Sk rudlik: O klasztorze OO. Kapucynów w Krakowie. - E, Chwalewik: Zbiory polskie. T, 1 s, 221. - 
M. Skrudlik: Sw. Franciszek Seraficki s. 174-175. - M. Skrudlik: Królowa Korony Polskiej s. 304. - J. Orańs ka: Szymon Czechowicz s. 98-101.

13

Bł. Bernard z Ofidy, kapucyn, w zwieńczeniu ołtarza św. Franciszka, $67 \times 81 \mathrm{~cm}$, płótno, olej. W owalu popiersie świętego z siwą brodą, w brązowym habicie, $z$ twarzą trzy czwarte $z$ prawo, $z$ otwartą księga $w$ ręce. Tło ciemne. Koniec XVIII w.

Bibliog rafia: AKK, rkps 38: Inwentarz z r. 1839 k. 4v. - AKK, rkps 39: Inwentarz z r. $1821 \mathrm{k} .18 \mathrm{v}, 64,64 \mathrm{v}$; Inwentarz z r. $1858 \mathrm{k} .102$; Inwentarz z r. 1871 k. 147v. - AKK, rkps 40: Inwentarz z r. 1875 s. 22. - APK, rkps - O. P. K och a ń s ki: Kościół Zwiastowania s. 67.

\section{4}

Wizja św. Antoniego, w ołtarzu św. Antoniego, w drugiej kaplicy z prawej strony nawy, $105,5 \times 178 \mathrm{~cm}$ w świetle ram, płótno, olej. Święty klęczy $\mathrm{z}$ twarzą trzy czwarte $\mathrm{w}$ lewo, $\mathrm{z}$ rękami złożonymi na piersiach, w habicie kapucyńskim. Z lewej strony objawione Dziecię Jezus, wyciągające prawą rączkę w stronę świętego. Na ziemi leży otwarta księga i biała lilia, atrybut jkonograficzny świętego. Twarz św. Antoniego jest uosobieniem dobroci i radości. Obraz pochodzi zapewne z lombardzkiej szkoły malarstwa religijnego i jest, być może, dziełem jednego z uczniów Giuseppe Marii Crespi'ego. Sygn. u dołu z prawej strony: „Bologna. In Italia” 1775 r. Cena 24 dukaty.

$\mathrm{B}$ i b li o g rafia: $\mathrm{AKK}$, rkps HCC, I s. 169. - AKK, rkps 38: Inwentarz z r. 1839 k. $4 \mathrm{v}$. - AKK, rkps 39: Inwentarz z r. $1821 \mathrm{k} .18 \mathrm{v}, 19,64 \mathrm{v}$; Inwentarz z r. 1858 k. 102: Inwentarz z r. $1871 \mathrm{k} .147 \mathrm{v}, 148$ - APK, rkps - O. P. K o c h a ńs ki: Kościól Zwiastowania s. 67,68 . - O. W. Now a k ow ski: Pamiątka s. 20.M. Skrudlik: O klasztorze OO. Kapucynów w Krakowie.

\section{5}

Bł. Bernard z Corleone, kapucyn, w zwieńczeniu ołtarza św. Antoniego, $68,5 \times 82,5 \mathrm{~cm} \mathrm{w}$ świetle ram, płótno, olej. Popiersie świętego w owalu, $z$ twarzą trzy czwarte $w$ prawo, $z$ rękami złożonymi od modlitwy nad otwartą księgą, w brązowym habicie. Tło ciemne. II poł. XVIII w.

$\mathrm{B}$ ibliografia: AKK, rkps 38: Inwentarz z r. $1839 \mathrm{k}$. 4v. Autor inwentarza twierdzi, że obraz przedstawia św. Serafina $z$ Montegranario, kanonizowanego w r. 1767. - AKK, rkps 39: Inwentarz z r. 1821 k. 18v, 19, 64v; Inwentarz z r. 1858 k. 102; Inwentarz z r. 1871 k. 147v, 148. - AKK, rkps 40: Inwentarz z r. 1875 s. 22 . - APK, rkps O. P. K o chańs ki: Kościól Zwiastowania s. 68.

\section{6}

Boże Miłosierdzie, w kaplicy św. Feliksa na filarze, $78 \times 137 \mathrm{~cm}$, płótno, olej. Chrystus w pozycji frontalnej, en face, w białej szacie, prawa ręka wzniesiona na błogosławieństwa, lewą wskazuje na Serce, z którego wypływają dwie smugi białoczerwonych promieni. Tło ciemne $z$ czerwonymi punktami przedstawia plonącą Warszawę (1944). Sygn. u dołu „Hyła 1944”. Poświęcenie obrazu odbyło się 3 grudnia $1944 \mathrm{r}$.

Bibliografia: AKK, rkps HCC, IV s. 364. - AKK, rkps HCC, IVa s. 17. APK, rkps - Br. E. Chmi e 1: Kronika s. 86, 121. - APK, rkps - O. P. K oc h a ́n s ki: Kościól Zwiastowania s. 61.

\section{7}

Św. Feliks z Cantalice, kapucyn, w oltarzu św. Feliksa, w pierwszej kaplicy z lewej strony nawy, $115 \times 225 \mathrm{~cm}$ w świetle ram, płótno, olej. Swięty w brązowym habicie kapucyńskim, z siwą brodą, w pozycji klęczącej 
z prawej strony, w profilu lewym, lekko pochylony, z Dzieciątkiem Jezus na rękach. $\mathrm{Z}$ lewej, $\mathrm{u}$ dolu, niewiasta $\mathrm{w}$ białej szacie $\mathrm{i}$ czarnym kaftaniku, wyciąga do świętego obie ręce $\mathrm{w}$ kornej prośbie. Ponad świętym, z prawej strony, dwie uskrzydlone główki aniołków, z lewej - anioł w czerwonej szacie i niebieskim płaszczu, wkładający wieniec chwały na głowę świętego. Późnobarokowy. XVIII w.

Bibli ografia: AKK, rkps 38: Inwentarz z r. $1839 \mathrm{k} .4 \mathrm{v}$. - AKK, rkps 39: Inwentarz z r. $1821 \mathrm{k} .18$, 63v; Inwentarz z r. $1858 \mathrm{k} .101 \mathrm{v}$; Inwentarz z r. 1871 -k. 147. - AKK, rkps 40: Inwentarz z r. 1875 s. 20. - APK, rkps - O. P. K och ański: Kościól Zwiastowanıa s. 63. - O. W. Nowakowski: Pamiątka s. $17-18$.

Św Teresa od Dzieciątka Jezus, na predelli oftarza św. Feliksa, $36 \times 45 \mathrm{~cm}$, płótno, olej. Popiersie, w brązowym habicie, białym płaszczu i niebieskim kornecie, twarz trzy czwarte $w$ prawo, w rękach krzyz i róże. $Z$ prawej snop promienj oświetla krzyż. Tło jasnozielone. I pol. XX w.

Bibliografia: APK, rkps - O P. Kochański: Kościół Zwiastowania s. 63.

\section{9}

Oblicze Pana Jezusa na chuście św. Weroniki, w zwieńczeniu ołtarza św. Feliksa, $57 \times 73 \mathrm{~cm}$ w świetle ram, plótno, ole j. Jasne oblicze z ciemnymi włosami, na tle białej chusty. XVIII w.

Bibliografia: AKK, rkps 38: Inwentarz z r. 1839 k. 4v. - AKK, rkps 39: Inwentarz z r. 1821 k. 18, 63v; Inwentarz z r. 1858 k. 101v; Inwentarz z r. 1871 k. 147. - AKK, rkps 40; Inwentarz z r. 1875 s. 20. - APK, rkps - O. P. K ochański: Kościól Zwiastowania s. 63.

Matka Boska Ostrobramska, w niszy między kaplica św. Feliksa a kaplica św. Erazma, $95 \times 128,8 \mathrm{~cm}$ w świetle ram, płótno, olej. Madonna z głową lekko pochyloną, z podwójną koroną, wysadzaną kamieniami, z aureola ze złotych promieni, między którymi widnieje 12 gwiazdek. Ręce złożone do modlitwy. $\mathrm{Na}$ szyi 5 sznurów czerwonych korali i trzy białych, w tym dwa z. krzyzykami. Tło ciemnoniebieskie. Obraz przywieziony w ramach repatriacji po drugiej wojnie światowej. W r. 1951 wzniesiono dla niego osobny ołtarz. I poł. $\mathrm{XX}$ w.

Bibliografia: AKK, rkps HCC, IV s. 406. - AKK, rkps HCC, IVa s. 72.APK, rkps - Br. E. Chmiel: Kronika s. 178. - APK, rkps - O. P. Kochańs k i: Kościól Zwiastowania s. 63.

\section{1}

Św. Kajetan, w ołtarzu św. Kajetana, w drugiej kaplicy z lewej strony nawy, $116,5 \times 227,6 \mathrm{~cm}$ w świetle ram, płótno, olej. $Z$ lewej strony klęczy święty w czarnym habicie teatynów, w profilu prawym, i przyjmuje $z$ rąk Matki Bożej Dzieciątko Jezus, które wyciaga raczki do niego. Suknia Madonny cynobrowa, płaszcz błękitny. U dołu dwa putta, jeden z bukietem kwiatów, drugi wskazuje telzst Ewangelii św Mateusza 6, 24-33: Ne solliciti sitis, quid... Respicite volatilia coeli... Considerate lilia agri. Ponad sceną w chmurach grupa puttów. Farby cynobrowa i niebieska dominują równiez w ich szatach. Dotychczas artyści malarze przedstawiali św. Kajetana z Dzieciątkiem Jezus na rękach lub z białą lilią w ręku a więc symbolem czystości. Orłowski prawdopodobnie skopiował podniszczony juz oryginalny 
obraz Dandiniego, który z oltarza usunięto, a zastąpiono kopią wykonaną przez niego. Sygn. z lewej u dołu: „Gen. Lucas Orłowski. Pinxit Cracoviae A. 1763 die 8 Julii".

Bibliografia: AKK, rkps 38: Inwentarz z r. $1839 \mathrm{k}, 4 \mathrm{v}$. - AKK, rkps 38: Inwentarz z r. $1821 \mathrm{k} .18,18 \mathrm{v}, 64$; Inwentarz $\mathrm{z}$ r. $1858 \mathrm{k} .101$; Inwentarz z r. 1821 k. 147, 147v. - AKK, rkps 40: Inwentarz z r. 1875 s. 20. - APK, rkps - O. P. Kochański (Kościół Zwiastowania s. 64) wspomina tylko o obrazie Dandiniego. Rastawiecki: Słownik malarzów polskich, II s. 84. - O. W. Nowakowski (Pamiątka s. 16) pisze jedynie o obrazie Dandiniego. $Z$ tego powodu, że kronika w tych latach nie byla prowadzona, o zmianie obrazu zapomniano. - M. Skrudli k: Królowa Korony Polskiej s. 302-303; na s. 222 reprodukcja obrazu.

\section{2}

Św. Erazm, biskup, męczennik, w ołtarzu św. Kajetana, umieszczony w charakterze stałego obrazu (natomiast obraz św. Kajetana jest na zasuwie), $99,5 \times 155,5 \mathrm{~cm}$ w świetle ram, płótno, olej. Święty w pozycji frontalnej, z twarzą lekko zwróconą w lewo, w białej szacie i purpurowej kapie, w lewej ręce ma pastorał i palmę męczeńska, prawą wskazuje purpurową mitrę z księgą, leżące na stoliku pokrytym zieloną narzutą. Z lewej strony, w górze, dwa putta. $Z$ prawej widoczny krajobraz z zarysem gór, spoza których przebija światło. Poniżej scena torturowania świętego. Tło niebieskozielone i brązowe. Sygn. z prawej strony u dołu: „L[ucas] O[rłowski]. a[nno] 1763"

Bibliografia: AKK, rkps HCC, IV s. 207. Do r. 1926 obraz św. Erazma znajdował się $w$ ołtarzu na krużgankach kaplicy Loretańskiej. W styczniu tegoż roku został usunięty wraz $z$ ołtarzem. Obraz zawieszono na tylnej ścianie kaplicy. Po rozszerzeniu kościoła, przez dobudowanie nowych kaplic z lewej strony nawy, obraz świętego ustawiono jako stały $w$ ołtarzu św Kajetana. - AKK, rkps 38: Inwentarz z r. 1839 k. 5. - AKK, rkps 39: Inwentarz z r. $1821 \mathrm{k} .24 \mathrm{v}, 70$; Inwentarz z r. 1858 k. 103; Inwentarz z r. 1871 k. 148. - AKK, rkps 40: Inwentarz z r. 1875 s. 26. - AKK, rkps - Br. E. Chmiel: Kronika s. 22. - APK, rkps - O. P K och a ń ski: Kościól Zwiastowania s. 63. - O. Florian [ $\mathrm{Jano} \mathrm{ch}$ a]: Loretto s. 21. O. Florian [Janocha]: Nowenna chorych i na operacje skazanych, strapionych do św. Erazma, biskupa i męczennika, w obrazie łaskami słynącego na Loretańskich krużgankach u OO. Kapucynów w Krakowie. Kraków 1913 s. 14-15. Autor niesłusznie przypisuje Stachowiczowi autorstwo obrazu; reprodukcja obrazu przed kartą tytułową.

23

Matka Boska Bolesna, na predelli oltarza św. Kajetana, $36 \times 45 \mathrm{~cm}$, deska, olej. Popiersie Madonny, $z$ twarza trzy czwarte $w$ lewo, z rękami złożonymi do modlitwy, w białej sukni i ciemnobrązowym płaszczu z białą podszewką. Tło ciemne. Kopia obrazu Tycjana. Oryginał znajdował się w galerii obrazów hr. Tarnowskich w Dzikowie. Pocz. XX w.

Bibliografia: APK, rkps - O. P. Kochański (Kościól Zwiastowrania s. 64) nie zna autora tak oryginalu jak i kopii obrazu. K. Grottow a: Zbiory sztuki Jana Feliksa i Walerii Tarnowskich w Dzjkowie (1803-1849). Wroclaw 1957 s. $119 \mathrm{nr}$ 149. W APK znajduje się fotografia obrazu z Dzikowa z napisem: „Fotografia obrazu Tycjana, własnos̉ci hr. Tarnowskich w Dzikowie".

\section{4}

Opatrzność Boża, w zwieńczeniu oltarza św. Kajetana, $59 \times 70 \mathrm{~cm}$, płótno, olej. Oko Opatrzności w promieniach. II poł. XVIII w.

Bibliografia: AKK, rkps 38: Inwentarz z r. 1839 k. 4v. - AKK, rkps 39: Inwentarz z r. 1821 k. $18 \mathrm{v}, 64$; Inwentarz z r. 1858 k. $101 \mathrm{v}$; Inwentarz z r. 1871 k. $147-147 \mathrm{v}-\mathrm{AKK}$, rkps 40: Inwentarz z r. 1875 s. 20. - APK, rkps O. P. Ko ch ańs ki: Kościól Zwiastowania s. 64 . 


\section{5}

Św. Anna, w przedsionku do kaplic z lewej strony nawy, $168 \times 120,5 \mathrm{~cm}$, płótno, olej. Swięta w profilu lewym, w niebieskiej sukni i czerwonym płaszczu, siedzi przy pulpicie i prawą ręką wskazuje na lezącą księgę. Obok niej, na wysokości głowy, anioł $w$ białej szacie $i$ niebieskim płaszczu $z$ białymi skrzydłami, prawą rękę wyciaga w niebo, skąd płynie struga światła. $Z$ lewej, mężczyzna w szarej szacie i czerwonym plaszczu, z rękami wzniesionymi w górę, zapatrzony $w$ światło, spływające $z$ nieba. Tło niebieskociemne 1 żółte. Sygn.: „Gen. Lucas Orłowski. Cracoviae 1763”.

Bibliog rafia: AKK, rkps 38: Inwentarz z r. 1839 k. 5. - AKK, rkps 39: Inwentarz z r. $1821 \mathrm{k} .24 \mathrm{v}, 70$; Inwentarz z r. $1858 \mathrm{k} .102 \mathrm{v}$; Inwentarz z r. 1871 k. 148v. - AKK, rkps 40: Inwentarz z r. 1875 s. 26. - APK, rkps - O. P. K 0chański: Kościól Zwiastowania s. 65. - Rastawiecki: Slownik malarzów polskich, II s. 84 .

\section{6}

Matka Boska, w przedsionku do kaplic z lewej strony nawy, 80,5 $\times 104 \mathrm{~cm}$, płótno, olej. Madonna do połowy postaci, en face, z Dzieciątkiem Jezus na lewej ręce. Ręce złożone na krzyż podtrzymują poły płaszcza. Na czole krzyżyk. Niebieski płaszcz zarzucony na głowę. Dziecię Jezus w lewej ręce trzyma księgę, a prawą wskazuje gwiazdę na prawym ramieniu Madonny. Złota aureola wokoło głów. Tło ściemnione. Sygn. u dołu z prawej: „Adalbertus Degowski. 1821 (?)". Dublowany, nalklejony na desce.

Bi bliog r a f i a: APK, rkps - O. P. Kochański (Kościól Zwiastowania s. 65) uważa, że obraz jest pochodzenia wschodniego i przypomina „odmianę "Hodogitrii» pod nazwą N. Panny Śnieżnej".

27

Matka Boska Bolesna, na ścianie w kaplicy Pana Jezusa, $56 \times 67 \mathrm{~cm}$, płótno, olej. Twarz trzy czwarte $w$ prawo, ręce złożone na krzyż na piersiach, niebieska chusta zarzucona na głowę. Tło ciemnobrązowe. Sygn.: „Sylw[eriusz] Saski". 1894 r.

Dar dra Rudolfa Radzyńskiego w 1960 r.

28

Pan Jezus cierniem ukoronowany, na ścianie kaplicy Pana Jezusa, $56,5 \times 69 \mathrm{~cm}$, płótno, olej. En face, w purpurowej szacie, która odsłania lewe ramię; na głowie cierniowa korona, czarne włosy spływają na ramiona. Tło ciemnobrazowe. Sygn.: „Sylw[eriusz] Saski. 1894”.

Dar dra Rudolfa Radzyńskiego w 1960 r.

29

Matka Boska Lorelańska, na zasuwie ołtarza w kaplicy Loretańskiej, $104 \times 242 \mathrm{~cm}$, plótno, olej. W pozycji frontalnej, stojącej, en face, z Dzieciątkiem Jezus na lewej ręce. Długie włosy opuszczone na suknię. Na głowach korony pozłacane. Wokoło głów aureola ze zlotych promieni i dwunastu gwiazd. Suknia zielona, z siedmioma zlotymi poprzecznymi pasami, ozdobiona gwiazdkami, serduszkami i innymi motywami zdobniczymi. Dzieciatko w podobnej sukience; w lewej rączce trzyma jabłko królewskie, a prawa błogosławi. Na postumencie, $u$ dołu, biały orzeł w koronie, w olsrągłym czerwonym polu. Z obu stron orła, u stóp Madonny, róże. Tło szare. Malował Michał Stachowicz w 1818 r. Na płótnie, u dołu, z prawej strony, data: „1860"; prawdopodobnie jest to rok konserwacji obrazu. 
Bibliografia: AKK, rkps HCC, I s, 383: D[omi]nus Michaël Stachowicz sua pictura gratis adornavit Loretum, per imaginem Beatissimae, quae obumbrat Statuam". — AKK, rkps 39: Inwentarz z r. 1858 k. 102; Inwentarz z r. 1871 k. 141. - AKK, rkps 40: Inwentarz z r. 1875 s. 24. Za inwentarzami z lat poprzednich podaje on, że obraz został wykonany w r. 1818 przez mal. Stachowicza. Thieme u. Becker, XXXI 432. - Nagler, XVII 197. - Rastawiecki: Słownik malarzów polskich, II s. 206. - E. Chw a le wik: Zbiory polskie. T. 1 s. 221.

Matka Boska Nieustającej Pomocy, na stoliczlku z lewej strony ołtarza w kaplicy Loretańskiej, 29,7 × 38,5 cm, blacha, olej. Matka Boska na złotym tle, o tradycyjnym wyglądzie. Obraz ten znajdował sie niegdyś na predelli ołtarza sw. Antoniego. W r. 1959 został przeniesiony na obecne miejsce. II pol. XIX w.

B ibliog a fia: AKK, rkps HCC, IV s. 472.

31

Miniatury na biurku króla Jana III Sobieskiego, w ilości 15, na pergaminie ( $z$ wyjątkiem $\mathrm{nr}$ 6, która jest na papierze), wykonane gwaszem. Przedstawiają sceny z życia Mojżesza i Józefa Egipskiego. Pochodzą prawdopodobnie z I poł. XVII w. D. M. Jakubiec doszła do wniosku, że „biurko z miniaturami mogło powstać w królewskiej manufakturze mebli artystycznych Ludwika XIV, założonej w 1662 r. Zaopatrywała ona dwory Europy w II poł. XVII w. Tam skupiała się wytwórezość miniatur, będących kopiami wielkich kompozycji mistrzów renesansu". Autorka pracy nie wyklucza możliwości powstania miniatur w kraju. "Przejście przez Morze Czerwone" zostało skomponowane prawdopodobnie w XIX w., a "Scena z Mojżeszem" (nr 3) w r. 1925. Biurko jest darem królewicza Jakuba Sobieskiego dla kościoła OO. Kapucynów w Krakowie (1733).

Miniatury nie są umieszczone na biurku w porządku chronologicznym. Zgodnie $z$ przyjętymi $w$ tej pracy zasadami podajemy je w kolejności topograficznej.

I. Srodkowa część biurka:

1. Przejście przez Morze Czerwone (Exod. XIV, 27-30), w górnej kondygnacji, $24 \times 26 \mathrm{~cm}$. Na pierwszym planie Mojżesz składa hołd Bogu za szczęśliwe przebycie morza. W jasnoróżowej szacie, $\mathrm{z}$ wyciągniętymi rękami modli się $\mathrm{w}$ otoczeniu uszczęśliwionych Izraelitów. W górze, w prawym i lewym rogu obrazu „głowy dmuchających zefirów”. Na dalszym planie rozszalałe morze zalewa zbrojne zastępy faraona. W górze nad sceną unosi się obłok Pański(?) z cyframi I, II, III. Znaczenie tych cyfr niezrozumiałe.

2. Złoty cielec przedmiotem kultu (Exod. XXXII, 1-6), na drzwiczkach tabernakulum, $15 \times 26 \mathrm{~cm}$.

3. Scena $z$ Mojżeszem, nad tabernakulum, $9 \times 6 \mathrm{~cm}$. Malowal Kazimierz Puchała w I poł. XX w.

II. Lewe skrzydlo:

4. Sprzedanie Józefa (Gen. XXXVII, 28), miniatura pierwsza z lewej strony, $16 \times 10 \mathrm{~cm}$.

5. Jakub przed faraonem (Gen. XLVII, 7), miniatura $z$ prawej strony nr 4 , $16 \times 10 \mathrm{~cm}$.

6. Wrzucenie Józefa do studni (Gen. XXXVII, 23) miniatura pod $\mathrm{nr} 4$, $16 \times 10 \mathrm{~cm}$. 
7. Józef tłumaczy sny faraonowi (Gen. XLI, 14-36), miniatura pod nr 5, $16 \times 10 \mathrm{~cm}$.

8. Oskarżenie braci o kradzież kubka (Gen. XLIV, 14-34), miniatura pod nr 6 , $16 \times 10 \mathrm{~cm}$.

9. Józef tłumaczy sny braciom (Gen. XXXVII, 5), $16 \times 10 \mathrm{~cm}$.

III. Prawe skr $\angle$ ydło:

10. Pan Bóg objawia się Mojżeszowi w krzaku gorejącym i daje mu cudowną laskę (Exod. IV, 3), miniatura pierwsza z prawej strony, $16 \times 10 \mathrm{~cm}$.

11. Mojżesz opuszcza górę Synaj z tablicami Dziesięcioro Przykazań (Exod. XXXIV, 29-31), miniatura obok $\mathrm{nr} 10,16 \times 10 \mathrm{~cm}$.

12. Objawienie się Pana Boga w krzaku gorejącym (Exod. III, 2), miniatura pod $\mathrm{nr} 10,16 \times 10 \mathrm{~cm}$.

13. Nojżesz uderzeniem laski w skalę wydobywa wodę (Exod. XVII, 6), miniatura pod nr 11, $16 \times 10 \mathrm{~cm}$.

14. Znalezienie Mojżesza w wodzie (Exod. II, 5-7), miniatura pod nr 12, $16 \times 10 \mathrm{~cm}$

15. Zbieranie manny (Exod. XVI, 14-19), miniatura pod $\mathrm{nr} 13,16 \times 10 \mathrm{~cm}$.

Bibliografia: AKK, rkps HCC, I s. 52. - AKK, rkps 1: Dokumenty fundacyjne kościola i konwentu $1683-1733$ k. $9 \mathrm{v}, 115-116 \mathrm{v}$. - AKK, rkps 39: Inwentarz z r. $1821 \mathrm{k} .25 \mathrm{v}, 69 \mathrm{v}$; Inwentarz z r. $1858 \mathrm{k} .102 \mathrm{v}$; Inwentarz z r, 1871 k. 148. - AKK, rkps 40: Inwentarz z r. 1875 s. 24, 26. - APK, rkps - O. K. G ad a c z: Historia klasztoru s, 22. - APK, rkps - O. P. K och ań s k: Kościół Zwiastowania s. 71, - Arch. Un. Jag., rkps - D. M. J a k u ble; Biurko Jana III Sobieskiego. Praca magisterska pisana pod kierunkiem prof. dr Karola Estreichera na UJ w Krakowie w r. 1956 (Tytuły miniatur i cytaty ze Stareoo Testamentu podane w zasadzie za autorką). [A. K l e c zkow k k] A.: Swięte pamiątki Krakowa s. 109. - O. W. Now a ko w k i: Pamiątka s. 23. - O. Florian [J a n o c h a]: Loretto s. 39-40. - M. S k r u d lik: O klasztorze OO. Kapucynów w Krakowie. - S. Tomkowicz: O artystach pracujących w Polsce s. LXXVI. - [O. A. Wojnar]: Polski Loret s. 56, 61-62, 64, 68. - O. K. G ad a c z: Inwentarz Archiwum s. 108. - B. Prend k a: Loreto. Gość niedz. R. 29: $1960 \mathrm{nr} 23$.

Šw. Konrad, kapucyn, na tylnej ścianie kaplicy Loretańskiej, $116 \times 163 \mathrm{~cm}$, płótno, olej. Na tle klasztoru kapucyńskiego, święty z lewej strony, w prawym profilu, w habicie kapucyńskim, z siwą drobą; prawą rẹką wręcza chlopcu chleb. Za chłopcem stoi kobieta. Z obrazka skopiowal Bieszczanin w r. 1934. W r. 1951 obraz oprawiono i umieszczono na obecnym miejscu.

Bibli og rafia: APK, rkps - Br. E. Chmiel: Kronika s. 183.

\section{3}

Stacje Drogi Krzyżowej, na krużgankach kaplicy Loretańskiej, każda o wym. ol. $81 \times 85,5 \mathrm{~cm}$, płótno, olej. I stacja: Jezus na ssmierć osazdzony. Chrystus $z$ prawej strony, w bladoniebieskiej sukni i czerwonym płaszczu, ze skrępowanymi rękami, po skazaniu na śmierć, prowadzony przez rzymskich żołnierzy. Z lewej Piłat Poncki, na tronie o trzech stopniach, umywa ręce. Wokoło Piłata grupa osób. Tło jasnobrązowe. Sygn. u dołu po prawej lub lewej: „Th[omas] Driendl in München". Odnowione w styczniu $1926 \mathrm{r}$. kosztem br. Sebastiana Porzuczka z Wolicy Piaskowej. II pol. XIX w.

Bibligrafia: AKK, rkps HCC, IV s. 207, - AKK, rkps - Inwentarz z r. 1875 s. 116. - Wiadomości kościelne i zakonne. Dzwonek III Zak. R. 1: 1885/86 nr 10 s. $337-338$. 
Serce Pana Jezusa, w zakrystii, $46 \times 58 \mathrm{~cm}$, płótno, olej. Popiersie en face, glowa lekko przechylonaw prawo, długie włosy blond spływają na różową suknię. Na lewym ramieniu zarzucony niebieski płaszcz. Prawą ręką zasłania gorejące serce. Tło niebieskie. 1957 r. Malował Antoni Bartkowski z Krakowa.

B ibli ografia: AKK, rkps HCC, IV s. 484.

35

Serce Pana Jezusa, w zakrystii, $56 \times 76 \mathrm{~cm}$, płótno, ole J. Popiersie, en face, w szacie zielonej, włosy spływają na szatę. Wokoło glowy jasna aureola na zielonkawym tle. Lewa ręka spoczywa pod. sercem, prawa zasłania gorejące serce. Sygn.: „E. Halban 1957”.

B ibli ografia: AKK, rkps HCC, IV s. 435. - APK, rkps-Br. E. Chmiel: Kronika s. 205.

\section{6}

Chrystus ukoronowany cierniową koroną, w zakrystii, $48 \times 56 \mathrm{~cm}$, plótno, olej. Popiersie, twarz trzy czwarte w lewo, włosy czarne. Na głowie srebrna korona cierniowa a $u$ dołu fragment srebrnej szaty. Korona i szata wykonane ze srebra. Na odwrocie obrazu napis: ,Ten obraz Chrystusa równiez / Passyjka $z$ wielebnym P. Jezusem | ma zostać we familii Mączyńskich | po starszeństwie. | Takie było rozporządzenie | Wiktoryj z Mączyńskich | Czechowej | zmarłej dnia 29 Października | 1852 | Pisał to wykonawca woli zmarłej ! Kraków. d. 13 listopada | 1852 Józef Czech". Płótno rozciągnięte na desce. I poł. XIX w. W r. 1953 obraz odnowiono.

Bibliografia: APK, rkps - Br. E. Chmiel: Kronika s. 317.

\section{7}

Pan Jezus między doktorami, w zakrystii, $52 \times 86 \mathrm{~cm}$, płótno, olej. Fragment świątyni jerozolimskiej. Na potrójnym podwyższeniu, pod półkopułą wspartą na kolumnach, stoi Pan Jezus w pozycji frontalnej, z blond włosami i w niebieskiej szacie. W prawej ręce trzyma otwartą księgę, a lewą wznosi $w$ niebo. $Z$ prawej strony, na ławie, siedzi trzech uczonych żydowskich, z lewej czwarty. Z lewej strony, Matka Boska, z twarzą zwróconą ku św. Józefowi, stojącemu za nią, wskazuje prawą ręką na Pana Jezusa. Na ramie napis: „OO. Kapucynom. M. Tekielski r. p. 1959”.

\section{8}

Tryptyk ołtarzowy z obrazem Matki Boskiej Częstochowskiej, w skarbcu kościelnym. Wymiary: tryptyk zamknięty: $45 \times 60 \mathrm{~cm}$; tryptyk otwarty: $90 \times 60 \mathrm{~cm}$, deska, olej. XX w.

Tryptyk zamknięty:

Prawe skrzydło: Sw. Jerzy w złotym pancerzu, w pozycji frontalnej, z twarzą trzy czwarte $w$ prawo, lekko pochylony $w$ dól, na piersiach krzyż, na prawym ramieniu purpurowy plaszcz, wokoło głowy zlota aureola. W prawej ręce dzierży biały sztandar z czerwonym krzyżem, w lewej miecz, którym przebija smoka. Prawą nogą depce smoka. Tho zielonkawe.

Lewe skrzydło: Sw. Michał Archanioł, w pozycji frontalnej, en face, z głowa pochyloną $w$ prawo, $w$ złotej aureoli i takim pancerzu, $z$ wielkimı, czerwonozłotymi skrzydlami. $W$ prawej ręce trzyma wagę, $w$ lewej miecz. $Z$ prawej, w górze, smuga jasnych promieni. Tło zielonkawe. 
Tryptyk otwarty:

Srodkowe skrzydło: Matka Boska Częstochowska z Dzieciątkiem Jezus na lewej ręce, w złotych koronach. Suknia Madonny czerwona, płaszcz zielony, zdobny $w$ złoie floresy; sukienka Dzieciątka zielona w złote gwiazdki. Wokoło korony 12 złotych gwiazd. Korony i gwiazdy są płaskorzeźbami. Tło złote.

Prawe skrzydło: Św. Jadwiga Sląska z kościólkiem w lewej ręce i zieloną palmą $w$ prawej, twarz trzy czwarte $w$ prawo, w czerwonej szacie. Za nią bł. Salomea $w$ białym habicie i czerwonym płaszczu, spiętym klamrą. Na płaszczu, przy klamrach, dwa czarne piastowskie orły bez koron. Tło zlote.

Lewe skrzydło: Sw. Jacek w białym habicie, w prawej ręce kielich, w lewej figurka Matki Boskiej. Za nim św. Stanisław ze Szczepanowa, w złotej mitrze, białej szacie i purpurowej kapie. W lewej ręce złoty pastorał, w prawej wielka tarcza ze zlotym orłem $\mathrm{w}$ koronie na czerwonym polu. I pol. XX w. Według tradycji klasztornej jest to ołtarz polowy wojsk polskich z r. 1939 i Armii Krajowej $z$ okresu okupacji.

\section{9}

Herb zakonu, w chórze zakonnym, $75,5 \times 120 \mathrm{~cm}$, płótno, olej. Dwie ręce skrzyzowane, jedna Chrystusa, druga św. Franciszka, a w środku krzyż w aureoli. Tło niebieskie. XVIII w. Dwa obrazy wiszące $z$ obu stron krucyfiksu.

40

Stacje Drogi Krzyżowej, w chórze zakonnym, każda o wym. ok. $60,5 \times 84,5 \mathrm{~cm}$, płótno, olej. I stacja: Jezus na śmierć osądzony. $\mathrm{Na}$ pierwszym planie Jezus, w koronie cierniowej, w niebieskiej szacie i purpurowym plaszczu, $\dot{w}$ pozycji frontalnej, $z$ rękami skrępowanymi sznurem, którego Lońce clągnie żołdak z prawej, a z lewej drugi popycha Jezusa. Z prawej, na podwyższeniu, Piłat $w$ białej tunice i różowawym płaszczu, na tronie, ze złamanym berłem $w$ obu dłoniach. Obok z prawej zloty dzbanek na złotej tacy. $Z$ lewej rzymscy żołnierze $z$ czerwonym sztandarem, na którym widnieją inicjały: S.P.Q.R. Tło zielonoczerwone i brązowe. XVIII w. Późnobarokowe. Na odwrocie stacji napis: „Za staraniem O. Kapucyna Brata Remigiusza [Serwonskiego] wyrestaurowane roku 1858" i „Odnowiono 1886". Dodany spleciony inicjał: „J.Z." (Józef Zajączkowski ?). Prawdopodobnie stacje te znajdowały się wpierw w kaplicy Loretańskiej. Z chwilą, gdy na krużganki sprawiono nową Droge Krzyżową, zapewne w II poł. XIX w., dotychczasowe stacje przeniesiono do chóru zakonnego.

Bibliografia: AKK, rkps 38: Inwentarz z r. 1839 k. 5. - AKK, rkps 39: Inwentarz z r. 1817 k. 11v: "Stacyi na płótnie malowanych na ganku Loret. 14"; Inwentarz z r. 1859 k. 177; Inwentarz z r. 1871 k. 168. - AKK, rkps 40: Inwen$\operatorname{tarz}$ z r. 1875 s. 118.

41

Sw. Franciszek Seraficki, w chórze zakonnym, $60 \times 80 \mathrm{~cm}$, płótno, olej. Półpostać, w habicie kapucyńskim, w kapturze na głowie, z białym paskiem i różańcem. Twarz trzy czwarte w lewo, ręce złozone na krzyż na piersiach, z oczu płyną łzy. Wokoło głowy biała aureola. Tło brązowe. XVIII w.

B ibliografia: AKK, rkps 38: Inwentarz z r. 1839 k. 6. - AKK, rkps 39: Inwentarz z r. 1821 k. 26, 48. - AKK, rkps 40: Inwentarz z r. 1875 s. 118.

\section{2}

Św. Fidelis z Sigmaringen, kapucyn (beat. 1729, kan. 1746), w chórze zakonnym, $70 \times 108 \mathrm{~cm}$, plótno, olej. Twarz trzy czwarte w prawo, z siwą 
brodą, cała postać lekko zwrócona w prawo. W lewej rẹce mały krzyżyk przyciśnięty do serca, w prawej wyciągniętej przed siebie obejmuje większy krzyz w niemej adoracji. Wokoło głowy aureola zaznaczona czarna linią owalu. Tło brązowe. Uszkodzony przez wilgoć. I poł. XVIII w.

Bibliografia: AKK, rkps 40: Inwentarz z r. 1875 s. 114.

43

Św. Józef z Leonessy, kapucyn (beat. 1737, kan, 1746), w chórze zakonnym, 70,5 X $108 \mathrm{~cm}$, płóino, olej. Twarz trzy czwarte w lewo, głowa łysa, broda siwa, cała postać lekko gbrócona w lewo. Aureola wokoło głowy zaznaczona czarną linią owalu. W brązowym habicie i białym pasku z różańcem. W prawej ręce trzyma krzyż misyjny, wzniesiony w górę na wysokość ramienia, lewą wskazuje na niego. $Z$ prawej, w górze, dwa aniołki. Tło brązowe. I pol. XVIII w.

Bibliografia: AKK, rkps 40: Inwentarz z r. 1875 s. 114. Oba ostatnie płótna powstały $w$ jednym czasie i wykonał je ten sam malarz. Posiadają bowiem te same wymiary, kompozycję, a nawet cenę $(15 \mathrm{złr})$. Na podstawie opisu kroniki krakowskiej (AKK, rkps HCC, I s. 96) można wnioskować, iż ich twórcą był malarz z Pragi, Jerzy Neunstäter i że wykonane zostały w r. 1747, na uroczystości związane z kanonizacją obu świętych, które odbyły się w kościele OO. Kapucynów w Krakowie $z$ wielką okazalością. Obraz św. Józefa znajdował się na ołtarzyku od strony Lekcji, a św. Fidelisa na ołtarzyku od strony Ewangelii.

\section{4}

Św. Weronika Giuliani, kapucynka (beat. 1802, kan. 1839), 29,5 $\times 45 \mathrm{~cm}$, płótno, olej. W brązowym habicie, głowa przechylona całkiem w lewo, ku krzyżowi, który trzyma w prawej ręce, lewa wyciągnięta w bok. Na czerwonym sercu emblematy Męki Pańskiej. U dołu obrazu napis: „Venerabilis w chmurach nad kula ziemską, wśród aniołów grajacych na harfie i trąbce Mater | Veronica Juliani Capucinarum | Abbatissa in cuius Corde inventa fuit | Passio Christi in Civitate Burgi Provinciae Assisiensis | mortua et sepulta die 9 Julii | 1727 Anno". Tło brązowe. XVIII w.

Bibliografia: AKK, rkps 38: Inwentarz z r, 1839 k. 6. - AKK, rkps 39: Inwentarz z r. 1821 k. 26, 48; Inwentarz z r. 1858 k. 101v. - AKK, rkps 40: Inwentarz z r. 1875 s. 118. - Collectanea Franciscana (T. 31: 1961 fasc. 3) zawiera szereg prac poświęconych świętej pod ogólnym tytułem: „Veronica Giuliani vitae spiritualis magistra et exemplar tertio ab eius nativitate exeunte saeculo (16601960)". - Bogatą bibliografię podaje Lex. cap. szp. 1801-1803.

\section{5}

S̄w. Juda Tadeusz, w chórze zakonnym, $37 \times 45 \mathrm{~cm}$, płótno, olej. W białoczerwonej szacie i błękitnym płaszczu, zwisajacym $z$ lewego ramienia i podwiązanego brązowym paskiem. W prawej ręce trzyma laskę, a w lewej obraz Zbawiciela. Tło brazowe. II poł. XIX w. Nie notowany w żadnym $\mathrm{z}$ inwentarzy $\mathrm{w}$ klasztorze krakowskim.

\section{6}

Sw. Jan Nepomucen, w chórze zakonnym, $35,5 \times 45 \mathrm{~cm}$, płótno, olej. Glowa trzy czwarte w lewo, wokoło niej aureola z 5 gwiazd. W białej komży, $\mathrm{w}$ modrej pelerynce $\mathrm{z}$ czerwonym podbiciem. W prawej rece krucyfiks a w lewej palma męczeńska. $Z$ lewej, na stoliku nakrytym zieloną narzutą, księga złoty klucz i czarny biret. Tło brązowe. II poł. XIX w. 
Portret o. Jana Baptysty Dembińskiego, w chórze zakonnym, 29,5 $\times 45,5 \mathrm{~cm}$, płótno, olej. Półpostać w owalu, w brązowym kapucyńskim habicie, twarz trzy czwarte $w$ prawo, w lewej ręce trzyma krzyż, oparty o pulpit. Prawą ręką podtrzymuje księgę, która leży otwarta przed nim na stoliku. U dołu

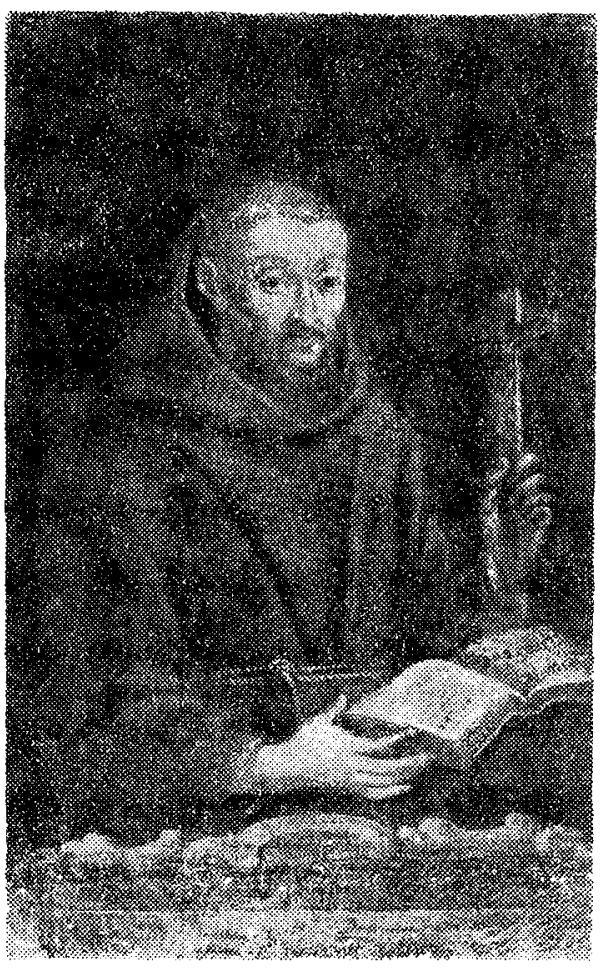
napis: ,V[e]n[era]b[i]lis PLate]r Joannes Baptista Capucinus Valentini | Dembiński Supremi Cancelarij Regni expost Castellani | Cracoviensis Filius. In Provincia Anterioris Austriae S. Fidelis / Lector Guardianus Costus Definitor. In magna Sanctitatis I fama Obijt Constatntiae die 7 Januarij Anno | 1632 Anno". Tło brązowe.

Jest to kopia wykonana w r. 1761 $z$ portretu $z$ refektarza klasztoru $O O$. Kapucynów w Konstancji, na prośbę o. Modesta z Krakowa, staraniem o. Reinharda a Lethenville, gwardiana konwentu w Konstancji. Kopii było kilka, które z kolei polecił sporządzić o. Modest. Jedną miał u siebie w klasztorze w Olesku, druga znajdowała się w klasztorze w Uściługu. Będąc w Lublinie kazał zrobić jeszcze kilka kopii, m. in. dla klasztoru we Lwowie, oraz polecil wysztychować miedzioryt dla konwentu w Warszawie. O. Modest zmarł w Krakowie 6 stycznia 1792 r. i prawdopodobnie pozostawił po sobie omawiany portret. Napis pod portretem pochodzi od o. Modesta, który przez 14 lat otrzymał wiele łask za pośrednictwem o. Jana Dembińskiego; stąd ta cześć dla niego. Niestety, łaski te nie zostały spisane. Pozostał natomiast życiorys o. Jana opracowany przez o. Modesta w języku łacińskim. Oryginał biografii spłonął w r. 1944 w Bibliotece Narodowej w Warszawle. Zachowało się jedynie streszczenie w języku polskim, dokonane przez o. Zenona Gorlickiego.

B i b li o grafia: AKK, rkps 38: Inwentarz z r. 1839 k. 6. - AKK, rkps 39: Inwentarz z r. $1821 \mathrm{k} .26,48-48 \mathrm{v}$. - AKK, rkps 40: Inwentarz z r. 1875 s. 118 . APK, rkps 148: Materiały. Życiorys świątobliwego o. Jana Dembińskiego k. 4 14. - APK, rkps 165: O. ż. Gor li cki: Notatki s. 64, 101, 103-104, 108-218. Lex. cap. szp. 845 (podana bibliografia). - M. B a li ń ski: Fundacja zakonu i kościoła Księży Kapucynów w Warszawie. Alleluృa. R. 1: 1840 s. 109. Ks. J. Fijałe k: Zamierzona osada zakonu „Kapuciańskiego" w Pałacu Spiskim na rynku w Krakowie $1683 / 5$ roku. Kwart. hist. R. 10: 1896 s. 313 . - Z. O bertyński: Das Werden und Wirken der polnischen Kapuzinerprovinz vor der Teilung des Reiches (1680-1795). Collect. francis. A. 8: 1938 fasc. 2/4 s. 195-197. Ks. Obertyński błędnie odczytał imię autora listu z 28 września 1761. Brzmi ono 
Reinhardus a Rottweil (Lex. cap. szp. 154). - A. Tom c zak: Walenty Dembiński, kanclerz egzekucji (olk. 1504-1584). Torun 1963 (Rocz-i TNTor. R. 67: 1962 z. 2) s. $154-155$.

\section{Korytarz parterowy}

\section{8}

Alegoria śmierci, $190 \times 96 \mathrm{~cm}$, płótno, olej. Wokoło płótna 6 piszczeli. Śmierć zabiera: papieza, króla, biskupów. W trumnie pastoral, berła, karta i kostki do gry. Z lewej strony nagie dziecko puszcza bańki mydlane. Szkielet króla w koronie i purpurowej kapie, w ręce klepsydra. Jeden piszczel dzierzy kose, piszczele w trumnie. Tło ciemne. Barok. XVIII w.

Bibliografia: AKK, rkps 40: Inwentarz z r. 1875 s. $382,-0$. W. Nowakowski: Pamiątka s. 29. - J. Szablowski (Ze studiów nad ikonografią smierci w malarstwie polskim XVII wieku. Prz. powsz. R. 51: 1934 t. 201 s. 84104 i odb. Kraków 1934) nie wspomina o obrazach śmierci w klasztorze kapucyńskim.

\section{9}

Alegoria śmierci. Kompozycja podobna jak $w$ poprzednim obrazie $203 \times 96 \mathrm{~cm}$, płótno, olej. Wokoło płótna 6 czaszek. Śnierć zabiera: papieża, kardynała, cesarza w stroju koronacyjnym, $z$ berłem $w$ jednej i jabłkiem w drugiej ręce. Szkielet ludzki z klepsydrą. Tło ciemne. Barok. XVIII w.

Bibliografia - jak pod nr 48 .

50

Alegoria śmierci, $184 \times 92,5 \mathrm{~cm}$, płótno, olej. Wokoło płótna 6 czaszek. Śmierć zabiera zapłakaną niewiastę, kościotrup ciągnie ja za rękę. Prośba męża nie odnosi skutku. Tło ciemne. Barok. XVIII w.

Bibliografia - jak pod nr 48.

51

Alegoria śmierci, $185 \times 88 \mathrm{~cm}$, płótno, olej. Kompozycja podobna jak w poprzednim obrazie. Śmierć zabiera kapucyna. $Z$ lewej trumna $z$ kościotrupem, nad nim pochylony kapucyn, en face, z rozłożonymi rękami. $Z$ prawey strony klęczy młodzieniec, w profilu lewym, w żółtych spodniach i zielonej kurtce, prawą ręką wskazuje trumnę, w lewej trzyma książkę. Ponad nim widoczny kościotrup, który zagląda mu w oczy. Tło ciemnobrązowe. Barok. XVIII w

Bibliografia - jak pod nr 48.

52

Pokłon Trzech Króli i złozenie darów Jezusowi, $180 \times 132 \mathrm{~cm}$, płótno, olej. Z lewej Matka Boska, w czerwonej sukni, trzyma za rękę Dzieciątko Jezus $w$ białej sukience. Za nią stoi św. Józef z prawą ręką wyciągniętą do Jezusa. Dziecię Jezus $z$ twarzą trzy czwarte w prawo, wyciąga rączki do adorujących monarchów, którzy równocześnie skłładają dary: złoto, kadzidło i mirrę. Z lewej królowie w pokłonach, olśniewają bogatymi wschodnimi ubiorami. Tło ciemnobrązowe. Malował Pietro Dandini w r. 1700. Barok.

B ibliog r afia: AKK, rkps 38: Inwentarz z r. 1839 k. 4v. - AKK, rkps 39: Inwentarz z r. 1871 k. 169. - AKK, rkps 40: Inwentarz z r. 1875 s. 114. - APK, rkps - O. P. Ko chański: Kościól Zwiastowania s. 21. - S. Ciam i: Notizie s. 98, 106. - M. Skrudlik: Królowa Korony Polskiej s. 287-288. 
Narodzenie Pana Jezusa, $180 \times 132 \mathrm{~cm}$, płótno, olej. Z prawej strony Matka Boska w pozycji siedzącej, w czerwonej sukni, z twarzą trzy czwarte w lewo, trzyma w obu rękach Jezusa, który stoi na kolanach Madonny. $\mathrm{Z}$ lewej pasterze składają hołd Dziecięciu. $\mathrm{Z}$ wyjątkiem centralnych postaci a więc Madonny i Jezusa, pozostałe osoby ledwie widoczne. Tło ciemne. Malował Pietro Dandini w r. 1700. Barok.

Bibliog r afia: AKK, rkps 38: Inwentarz z r. 1839 k. 4v. - AKK, rkps 39: Inwentarz z r. $1871 \mathrm{k} .169$. - AKK, rkps 40: Inwentarz z r. 1875 s. 114. - APK, rkps - O. P. Kochański: Kościól Zwiastowania s. 21. - S. Ciampi: Notizie s. 98. - MI. Skru d li k: Królowa Korony Palskiej s. 288.

\section{4}

Św. Cecylia, $81 \times 113 \mathrm{~cm}$, płótno, olej. W pozycji frontalnej, stojącej, z glową lekko pochyloną w lewo, w sukni żółtej, prawa ręka wzniesiona w górę, lewa opuszczona w dół. Z lewej strony widoczne skrzypce. Tło czarnobrazowe. Barok. II poł. XVIII w.

Bibliografia: AKK, rkps 40: Inwentarz z r. 1875 s. 386.

\section{$\mathbf{5 5}$}

Pan Jezus Milatyński, $64 \times 89 \mathrm{~cm}$, płótno, olej. Na brązowym krzyżu, lekko zwróconym w prawo, Chrystus Ukrzyżowany $z$ głową opuszczoną. $\mathrm{Na}$ środkowej belce, w górze, na białej tablicy inicjały: INRI. U dołu obrazu napis: „I Skł̆oniwszy Głowę, Ducha Wypuścil”. II poł. XVIII w. Barok. Dar ks. kanclerza Dubieckiego z 1842 r.

Bibliogr afia: AKK, rkps 38: Inwentarz z r. 1839 k. 4v, - AKK, rkps 39: Inwentarz z r. 1871 k. 169. - AKK, rkps 40: Inwentarz z r. 1875 s. 388.

56

Ukrzyżowanie, $127 \times 184 \mathrm{~cm}$, płótno, olej. Pan Jezus na krzyzu z glowa opuszczoną w dół, z niebieską przepaską na biodrach. U stóp krzyza, z lewej strony, klęczy św. Franciszek w habicie kapucyńskim i rękami obejmuje krzyż, przytulając głowę do stóp Jezusa. Pod krzyzem czaszka i otwarta księga, z prawej strony porzucona szata. Z lewej strony krzyża dwa wielkie anioły $w$ szatach niebieskich $i$ zółtych, $z$ prawej anioł $z$ wyciągniętymi w niebo rękami, w niebieskiej szacie i zółtym płaszczu. Tło niebieskozielone i popielate. Malował Pietro Dandini w r. 1701. Barok.

Bibli og r afia: AKK, rkps HCC, I s. 8, 10. - AKK, rkps 38: Inwentarz z r. 1839 k. 4v. - AKK, rkps 39: Inwentarz z r. 1821 k. 40, 54v; Inwentarz z r. 1871 k. 168. - AKK, rkps 40: Inwentarz z r. 1875 s. 114. - APK, rkps O. K. G a d a cz: Historia klasztoru s. 11-12. - APK, rkps - O. P. K o c hań$\mathrm{ski:}$ Kościól Zwiastowania s. 21-22. - S. Ci a mpi: Notizie s. 98-99. M. Skrudlik: O klasztorze OO. Kapucynów w Krakowie. - M. Skrudlik: Sw. Franciszek Seraficki s. 174. Wbrew opinii autora obraz Dandiniego zachował się. - M. Skrudlik: Królowa Korony Polskiej s. 288-289, 291-292, 304.

\section{7}

Chrystus na krzyżu rozpięty, $95 \times 132 \mathrm{~cm}$, płótno, olej. Glowa opuszczona, włosy rude. Na plecy zarzucona biała chusta spływająca pięknymi fałdami, biodra owinięte zielonym perizonium. Tło niebieskie. I poł. XX w.

\section{8}

B1. Anioł z Akry, kapucyn, $36 \times 47,5 \mathrm{~cm}$, litografia. Błogosławiony w owalu, w pozycji frontalnej, $z$ rękami wyciągniętymi $w$ górę, unosi się 
w chmurach nad kulą ziemską, wśród aniołów grających na harfie i trąbce oraz jednego anioła, sypiącego kwiaty pod stopy kapucyna. Poniżej napis: ,Błogosławiony Anioł z Akry Missyonarz Kapucyn od Leona XII w poczet Błogosławionych policzony Roku Jubileuszowego 1825”. U dolu sygn.: ,w Warszawie w Litog[rafii] Inst[ytutu] Szkol[nego]”. „Lit[ograf] K[lemens] Iwaszkiewricz".

Bibliografia: AKK, rkps 38: Inwentarz z r. 1839 k. 9.

\section{9}

Sw. Fidelis, kapucyn, $90 \times 116 \mathrm{~cm}$, plótno, olej. W pozycji frontalnej, z twarzą trzy czwarte $w$ lewo, $z$ rękami wyciągniętymi w górę, w habicie i plaszczu kapucyńskim. Z lewej u dołu dwa putta w pozycji siedzącej, $\mathrm{z}$ twarzami zwróconymi $\mathrm{w}$ stronę świętego; jeden $\mathrm{z}$ nich trzyma $\mathrm{w}$ ręce szablę. I poł. XVIII w. Późnobarokowy.

B ibliogr a fia: AKK, rkps 39: Inwentarz z r. 1871 k. 168. - AKK, rkps 40: Inwentarz $z$ r. 1875 s. 114.

\section{0}

Sw. Hieronim, pustelnik, $89 \times 116 \mathrm{~cm}$, plótno, olej. W pozycji siedzącej, pochylony w lewo, z łysą glową i dużą siwą brodą; biodra owinięte czerwonym płaszczem. W prawej ręce trzyma krzyz, w lewej skrypt rozłożony na ziemi. Obok leży kilka książek. Tło brązowe. I poł. XVIII w. Późnobarokowy.

Bibliografia: AKK, rkps 40: Inwentarz z r. 1875 s. 382.

61

Św. Hieronim, doktor Kościoła, $98,5 \times 136 \mathrm{~cm}$, płótno, olej. W pozycji siedzącej, prawą ręką wspiera głowę, z dużą siwą brodą, zaczytany w otwartej księdze, którą trzyma w lewej ręce, opartą na kolanach. Z prawej strony świętego aniol $w$ niebieskiej szacie, $z$ munsztukiem długiej trąby w lewej ręce, w którą dmie, a prawą podtrzymuje z lewej strony od głowy świętego pozostały koniec trąby. Tło ciemne. I poł. XVIII w. Późnobarokowy.

62

Sąd Salomona, $63 \times 43 \mathrm{~cm}$, płótno, olej. Z lewej na tronie, o potrójnym podwyższeniu, siedzi król Salomon, w złotej koronie w purpurowym płasz-czu, w otoczeniu dworzan. Lewa ręką wskazuje nagie dziecię, które trzyma jeden z dworzan za prawą nóżkę a główką w dół. $\mathrm{Na}$ posadzce, w centrum, w pozycji klęczącej fałszywa matka, wskazuje prawą ręką nagie dziecię. Prawdziwa matka stoi obok kobiety $\mathrm{z}$ prawej strony. Pomiędzy nimi, na posadzce, leży martwe dziecko. Z prawej, barwny tłum osób i fragment kolumny. Tło zielonobrązowe i źółte. Prawdopodobnie szkoła wenecka. XVII w.

\section{3}

Pan Jezus obmywa nogi apostołom, $70,5 \times 55,5 \mathrm{~cm}$, plótno, olej. Wieczernik z kolumnami, w głębi stół, nakryty białym obrusem, z dzbanem i talerzykami. Na pierwszym planie, z lewej, Pan Jezus klęczy na podwyższeniu o jednym stopniu; odziany $w$ czerwona szatę, białym ręcznikiem umywa nogę apostoła w kamiennej brązowej misie. $Z$ lewej $i \mathrm{w}$ centrum grupa apostolów czeka na swą kolej. $Z$ prawej, na ziemi amfora $z$ wodą $i$ duży ręcznik. Z prawej apostoł, w żółtej sukni i czarnym płaszczu, pochylony nad 
stołkiem, wkłada sandały. Między nim a Panem Jezusem stoi Matka Boska w niebieskiej sukni i czerwonym płaszczu. Z sufitu zwisa złoty żyrandol. Tło źółtoczerwone i zielone. Prawdopodobnie szkoła wenecka. XVII w.

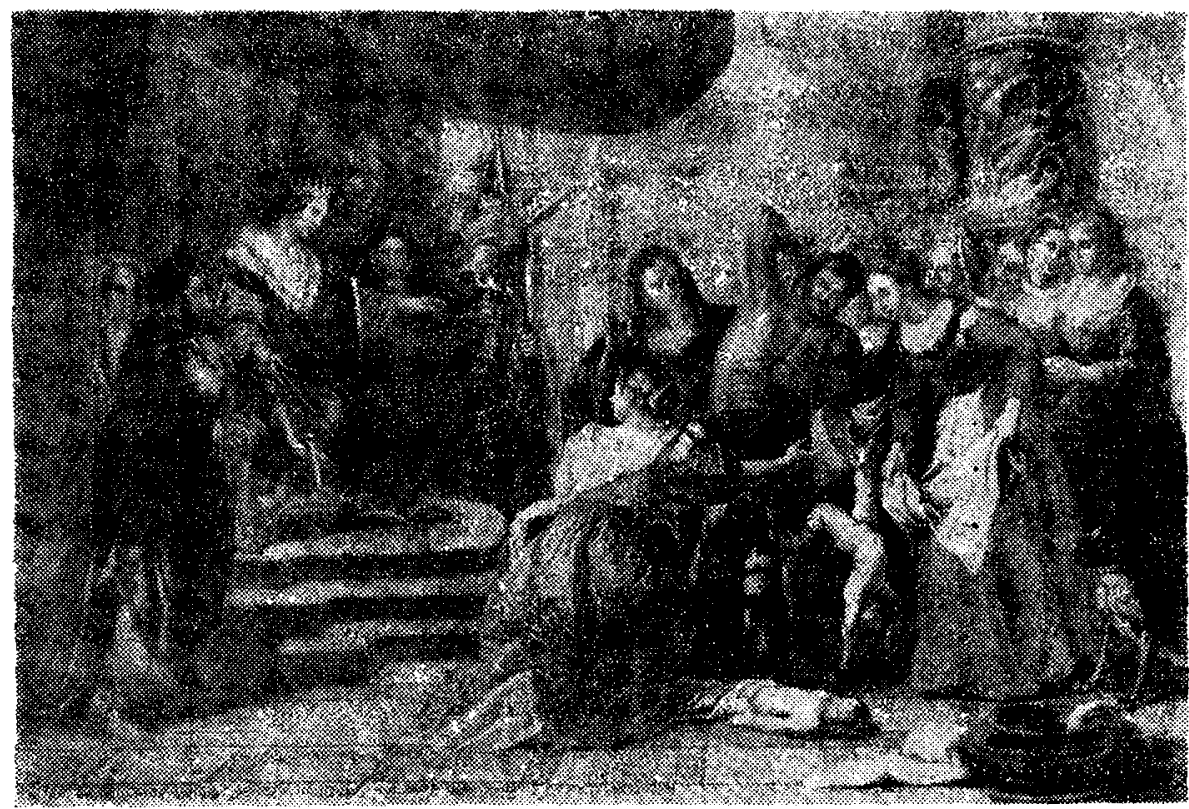

Sąd Salomona (62)

Refektarz

64

Pan Jezus Ulkrzyżowany, $96 \times 119, \mathrm{~cm}$, płótno, olej. Kopia obrazu Dandiniego $\mathrm{nr}$ 56, ale bez aniołów z boku. Poprzednio znajdował się na czołowej ścianie między obrazem Zwiastowania a Narodzeniem Pana Jezusa. Kopiował go drugorzędny malarz w r. 1720. Zapewne kilkakrotnie przemalowany. Obrazy nr 64, 65 i 66 stanowią jedną całość zajmując wschodnią ścianę refektarza. W r. 1937 rozłączono je i umieszczono w nowych ramach.

Bibli ografia: AKK, rkps HCC, I s. 40: "Die 22 9bris collocatae sunt in refectorio ad superiorem mensam imagines B[eati]ss[i]mae V[irginis] Annuntiatae, Nativitatis Jesu Christi et Crucifixi supra ianuam canapae". - AKK, rkps 38: Inwentarz z r. 1839 k. 9. - AKK, rkps 39: Inwentarz z r. 1821 k. 40,

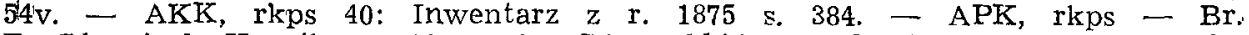
E. Chmiel: Kronika s. 10. - IM. Skrudlik: O klasztorze OO. Kapucynów w Krakowie. - N. Skrudlik: Królowa Korony Polskiej s. 302.

65

Zwiastowanie Najśw. Marii Panny, $228 \times 182 \mathrm{~cm}$, płótno, olej. W kompozycji i kolorystyce obiekt podobny do obrazu w wielkim oltarzu nr 1 , lecz znacznie poszerzony, przez co bardziej zbliża się do oryginału. Kopia $z$ obrazu Dandiniego, wykonana przez drugorzędnego malarza w r. 1720. Zapewne kilkakrotnie przemalowana.

Bibliografia - jak pod nr 64 . 
Narodzenie Pana Jezusa, $223 \times 179 \mathrm{~cm}$, płótno, olej. W środku obrazu Madonna $w$ pozycji siedzącej i frontalnej, w czerwonej sukni i niebieskim płaszczu. Lewą ręką podtrzymuje lezące na kolanach Dzieciątko Jezus a prawą rękę unosi nad nim. $Z$ prawej św. Józef, $z$ laską $w$ lewej ręce. W górze nad nimi dwa putta podtrzymują szarfę z napisem: „Gloria in excelsis Deo". Tło ciemne. Wykonany w r. 1720 przez drugorzędnego malarza i kilkakrotnie przemalowany. Późnobarokowy.

Bibliografia - jak pod nr 64 .

67

Portret o. Mateusza z Bascio, założyciela zakonu Kapucynów, $69 \times 93,5 \mathrm{~cm}$, płótno, olej. Popiersie w owalu, w brązowym habicie, z kapturem na głowie, twarz trzy czwarte w prawo, z siwawą brodą, z zamkniętą książką w prawej ręce. Tło ciemne. Pod owalem podpis: „Venerabilis Platelr Mathaeus a Bassio Ordinis / Minorum S[ancti] P[atris] Fr[ancisci] Reformationis nostrae Capucinorum | Primus Instaurator in magna Sanctitatis fama obiit Venetiis | Anno Domini 1551 post mortem clarus miraculis". Wykonany w r. 1794. Późnóbarokowy.

Bibliografia: AKK, rkps HCC, I s. 260. - AKK, rkps 38: Inwentarz z r. 1839 k. 9, - O. W. Now a ko w ski: Pamiątka s. 27.

68

Portret króla Jana III Sobieskiego, $71 \times 89 \mathrm{~cm}$, płótno, olej. Popiersie $z$ gołą głową, twarz trzy czwarte $w$ prawo, w lewej ręce trzyma srebrny szyszak, na srebrny pancerz zarzucona purpurowa delia, zapięta pod szyja srebrną spinką. Tło ciemne. I pol. XVIII w. Barokowy.

Bibliografia: AKK, rkps 38: Inwentarz z r. 1839 k. 9. - O. W. Nowakowski: Pamiątka s. 27: "wierna kopia z ofiarowanego przez samego króla portretu swego Kapucynom warszawskim". - M. Skrudlik: O klasztorze OO. Kapucynów w Krakowie. - E. Chwalewik: Zbiory polskie. T. 1 s. 222.

\section{9}

Portret o. Jana Dembińskiego, kapucyna, $69 \times 93,5 \mathrm{~cm}$, płótno, olej. W owalu popiersie, w kapucyńskim brązowym habicie, twarz trzy czwarte w prawo, z siwą brodą, w lewej ręce trzyma krzyż oparty o pulpit, na którym leży rozłożona księga. Poniżej owalu na białej szarfie podpis: „Venerabilis Pater. Joannes Baptista Capucinus Valentini / Dembiński Supremi Cancellary Regni expost Castellani Craco ! viensis Filius in Provincia Anterioris Austriae S. Fidelis | Lector Guardianus Custos Definitor. In magna San | ctitatis fama Obijt Constantiae dliel 7 Januarij 1632 Anno". Na odwrocie ramy znajduje się fragment czerwonej etykietki o wym. $2 \times 7,5 \mathrm{~cm}$ drukiem: „A. Bogdanowicz we Lwowie przy Placu Mariackim"; dalej tekst nieczytelny. Poniżej etykietki znajduje się druga o mniejszych wymiarach $z$ drukowanym tekstem: „A. BOGDANOWICZ we Lwowie / Skład papierów i / wszelkich przyborów do pisania I rysowania i malowania". Obraz ten jest skopiowany $\mathrm{z}$ płótna nr 47. Zawsze wisiał $w$ chórze zakonnym. Wykonany w r. 1794. Poźnobarokowy.

B ibliografia: AKK, rkps HCC, I s. 260. - AKK, rkps 38: Inwentarz z r. 1839 k. 9. - AKK, rkps 39: Inwentarz z r. $1821^{\prime} k .40$. - O. W. Now akowski: Pamiątka s. 27. 


\section{0}

Portret kardynała Ludwika Micary, kapucyna, $71,5 \times 100 \mathrm{~cm}$, płótno, olej. Popiersie w szerokim owalu, twarz trzy czwarte w lewo, z długą siwą broda, z purpurową piuską na głowie, ze złotym łańcuchem i pektorałem na piersiach. Tło ciemnobrązowe. Pod owalem na szarfie napis: „Frlater] Luciovicus a Tusculo Prov[inciae] Rom[anae] Gen[era]lis S.R.E. Ep[iscopus] Card[inalis] sub Pio VII a quo in Conclilio] Aul[icol eligitur per an[nos] 7 muneri incumbit". Portret został wykonany razem $\mathrm{z}$ obrazem $\mathrm{nr} 71 \mathrm{w}$ początkach II poł. XIX w. przez tego samego artystę.

Bibliografia: Lex. cap. szp. 1113-1114.

\section{1}

Portret kardynała Justusa Recanati, kapucyna, $71 \times 100 \mathrm{~cm}$, płótno, olej. Popiersie w szerokim owalu, twarz trzy czwarte $w$ prawo, $z$ siwa broda, z purpurową piuską na głowie i takiej sutannie, ze złotym łańcuchem i pektorałem na piersiach. Tlo jasnozielone. Pod owalem na szarfie napis: „Fr[ater] Justus Recanati, de Camerino, Ord[inis] Mino[rum] Capucin[orum] a Slanctis.s[imo] D[omino] N[ostro] Pio Plapa] P[ontifice] IX Creat[us] Card[inalis] die 1 Martlii] 1853". W pośrodku szarfy herb kardynała: w górnym jasnoniebieskim polu znajduje się herb Zakonu Kapucynów, w dolnym stojący lew na lewej nodze; ponad lwem trzy złote gwiazdki. Nad tarczą kapelusz kardynalski, którego frędzle zwisają $\mathrm{z}$ obu stron klejnotu.

Bibliografia: Lex. cap. szp. 1449-1450.

\section{2}

Portret kardynała Ignacego Persico, kapucyna, 67,5 $\times 95 \mathrm{~cm}$, płótno, olej. Popiersie w czarnym szerokim owalu, twarza trzy czwarte w lewo, z czarna brodą i takimi włosami, z purpurową piuską na głowie, w purpurowej sutannie, ze złotym łańcuchem i pektorałem na piersiach. Tło jasnobrązowe. Poniżej owalu na białej wstędze napis: „Em[inentissimus] P[ater] Ignatius Persico Ord[inis] Capucin[orum] n[atus] Neapoli 30 Janu[arii] 1823. Crealtus] Cardinalis 16 Janu[arii] 1893. Mortluus] Romae 7 Decem[bris] 1895". Pomiędzy wstęga a owalem herb kardynala: w górnym białym polu herb zakonu Kapucynów, w dolnym niebieskim na zielonej ziemi zielone drzewo. Ponad herbem purpurowy kapelusz kardynalski, którego 12 frędzli opada $\mathrm{z}$ obu stron klejnotu. Powyżej owalu stylizowana zlota szarfa $\mathrm{z}$ pięcioramienną złotą gwiazdką w środku. Sygn.: „D. A. 1897”. Portret zostal wykonany razem z obrazem nr 79 przez tego samego artystę.

Bibli ografia: Lex. cap. szp. 1334-1335.

\section{3}

Portret o. Wacława Nowakowskiego $(\uparrow 1903), 54 \times 70 \mathrm{~cm}$, plótno, olej. Popiersie w brązowym kapucyńskim habicie, twarz lekko zwrócona w prawo, oczy niebieskie, z siwą brodą i takimiż włosami. Tło jasnoniebiesłrie. Sygn.: „K. Rogalski, Pinxlit]. Kraków. 1909”.

B ib li o gr a fi: Lex. cap. szp. 1449-1450.

Stygmatyzacja św. Franciszka, $204 \times 158 \mathrm{~cm}$, plótno, olej. Na tle ciemnobrązowych, w dali widocznych gór i popielato-niebieskiego nieba, święty w pozycji klęczącej na Alwernii, w brązowym kapucyńskim habicie, w pro- 
filu lewym, $z$ jasną aureola wokoło głowy, $z$ dłońmi wzniesionymi przed siebie. Z lewej objawiony serafin na krzyżu, $w$ profilu prawym, $z$ krwawa koroną cierniową na głowie i skrwawionymi ranami na rękach, od których krwawe promienie uderzają $w$ dłonie świętego. Twarz św. Franciszka oświecona jasnym blaskiem od postaci serafina. Malował A. Hyła w r. 1953. Jest to kopia dziela Fryderyka Kunza, zamieszczonego w Heinrich Federer: Der heilige Franz von Assisi von Fritz Kunz (2 Aufl. München 1917) pomiędzy s. 36 i 37 .

Bibliografia: AKK, rkps HCC, IVa s. 88-89. - AKK, rkps HCC, IV s. 416. - APK, rkps - Br. E. Chmie l: Kronika s. 186. - APK, rkps O. P. Kochańs ki: Kościól Zwiastowania s. 66-67.

Portret kardynała Antoniego Barberini, kapucyna, $70 \times 94 \mathrm{~cm}$, płótno, olej. Popiersie w owalu, twarz lekko zwrócona w lewo, z czarną brodą, z czarnymi wlosami i purpurowym biretem na glowie. W zielonej sutannie z purpurowymi guziczkami. Tło ciemnobrązowe. Pod owalem napis: „Antonius Barberinus Summi Pontificis | Urbani VIII Frater secundum carnem et Frater Ff[rat]rum N[ostri] ord[inis] | Capucinorum (?) secundum Spiritum Cardinalis factus Tit[uli] SLancti] Onuphrii, Maioris ! Paenitentiarii Bibliothecarii Vaticani Urbis Officiis functus Ordinis Nostri | Cappucinorum (?) Protector et Conventus Romaní Fundator. Obiit Anno 1646 / Sepultus in Nostra Ecclesia quam Ipse fundavit cum hoc Apposito Epitaphio: Hic jacet pulvis Cinis et nihil". W pośrodku napisu herb kardynała. Wymalowany w r, 1794. Portret został wykonany razem $z$ płótnem nr 76 przez tego samego artystę.

Bibliografia: AKK, rkps HCC, I s. 260. - AKK, rkps 38: Inwentarz z r. 1839 k. 9. - Lex. cap. szp. 168-169.

Portret kardynała Franciszka Casini, kapucyna, $70 \times 94 \mathrm{~cm}$, płótno, olej. Popiersie w owalu, twarz lekko zwrócona w prawo, z rudą brodą, $\mathrm{z}$ purpurowym biretem na głowie $i \mathrm{w}$ zółtej sutannie $\mathrm{z}$ purpurowymi guziczkami. Pod owalem napis: „Fr[ater] Franciscus Maria Casinus Aretinus Ordinis Minorum Slancti] Francisci Capucinorum. Sacrae Theologiae Professor, Sacri $\mathrm{Pa} \mid$ latii Apostolici Concionator. S.R. E. Presbyter Cardinalis creatus | a S[anctis]s[i]mo D[omino] N[ostro] Clemente Papa XI in Consistorio Secreto habito semipublicum in Aula Ducali Palatii Vaticani die 18 Maii 1712". W pośrodku napisu herb kardynalski: tarcza podzielona dwoma złotymi poprzecznymi pasami na dwa białe pola. W dolnym polu jest ośmioramienna złota gwiazdka, w górnym dwie podobne gwiazdki. Ponad herbem purpurowy kapelusz kardynalski, z którego 12 frędzli opada $z$ obu stron klejnotu. II poł. XVIII w.

Bibliografia: Lex. cap. szp. 359-360.

77

Portret biskupa Beniamina Szymańskiego, kapucyna, $71 \times 100 \mathrm{~cm}$, płótno, olej. W pozycji siedzącej, z twarza trzy czwarte w prawo, z rudosiwą brodą, w fioletowej piusce, białej komży, brązowej pelerynie, ze złotym łańcuchem i krzyżem na piersiach. W prawej ręce trzyma fioletowy biret, lewa oparta na purpurowym fotelu. Tło jasnoniebieskie. $U$ dołu na białym tle napis: „P[ater] Beniamin Szymański, Capuclinus], Epliscolpus Podlachiensis. Per 
10 annos, Dioecesi cassata obiit in Conven[tul Nostro Łomżae Anno 1868". Malował Władysław Barwicki (?) w r. 1933.

Bibliografia: AKK, rkps HCC, IV s. 251. - Lex. cap. szp. 1664.

\section{8}

Portret kardynała Józefa Vives y Tuto, kapucyna, $54 \times 63 \mathrm{~cm}$, plótno, olej. Popiersie, w profilu lewym, z rudosiwą broda i o siwych włosach, z purpurowa piuską na głowie, w kapucyńskim brazowym habicie i płaszczu. Tło zielono-popielate. $U$ dołu napis: „Em[inentissimuls P[atelr Josephus Calas[anctius] Vives y Tuto (1854--1913) Cardinalis Diacon[us] 1899 - I Eccllesiae] S[anc]ti Adriani in Foro Romano”. Sygn.: „K. Rogalski. Kraków. 1900".

Bibliografia: Lex. cap. szp. 1829-1830.

\section{9}

Portret kardynała Wilhelma Massaii, kapucyna, $67 \times 95 \mathrm{~cm}$, płótno, olej. Popiersie w owalu, twarz lekko zwrócona w lewo, niebieskie oczy, duża siwa broda. Purpurowa piuska na głowie, purpurowa sutanna z kapturem, złoty łańcuch $\mathrm{z}$ pektorałem na piersiach. Na szerokiej wstedze owalu stylizowana gałązka z liśćmi. Poniżej owalu napis: „Em[inentissimus] P[ater] Gullielmus Massaia Ord[inis] Capucin[orum] in Piova d[ie] 8 Julii 1809 an[ni] Crea[tus] Cardinalis 10 Nov[embris] 1884. Mort[uus] in Neapoli 6 Aug[usti] 1889". Poniżej owalu tarcza herbowa. W górnym białym polu herb kapucyński z podwójnym krzyżem, w dolnym niebieskim biała ręka $z$ zieloną rośliną. Ponad tarczą purpurowy kapelusz kardynalski, którego 12 frędzli opada $\mathrm{z}$ obu stron klejnotu. Ponad owalem $\mathrm{w}$ górze stylizowana szarfa z pięcioramienną gwiazdą w środku. Sygn.: „D. A. 1897”.

B i b li o gr a fi a: Lex. cap. szp. 1068-1072.

\section{Pierwsze piętro}

80

Matka Boska z Dzieciątkiem, 76,5 ×95 cm, płótno, olej. Półpostać z twarzą trzy czwarte $w$ prawo, na lewej ręce Dzieciątko Jezus; w czerwonej sukni i ciemnobrazowym płaszczu. Prawa ręka zlożona na sercu. $\mathrm{Na}$ szyi dwa sznury korali i złoty łańcuch. Dzieciątko w koronie, z prawa rączka wzniesioną do błogosławieństwa. Z obu stron głowy Matki Boskiej putta. Tło ciemnobrazowe. Poniżej obrazu na tablicy napis: „Praetereundo cave ne teceatur Ave". Dawniej nad obrazem był drugi napis: "Tot tibi sint laudes Virgo quot sidera coeli". XVII w. Barokowy. Szkoła włoska.

Bi bliografia: AKK, rkps 38: Inwentarz z r. 1839 k. 8. - AKK, rkps 40: Inwentarz z r. 1875 s. 386 . - O. W. Now a k ow s k i: Pamiątka s. 28-29.

\section{1}

Maria Opiekunką Zakonu Dominikańskiego, $126,5 \times 149 \mathrm{~cm}$, płótno, olej. $\mathrm{Z}$ lewej, $u$ góry, Madonna $z$ twarzą trzy czwarte $w$ prawo, w czerwonej sukni i niebieskim płaszczu, obydwiema rękani rozpościera płaszcz nad zgromadzonymi w dole dominikanami i dominikankami. Z prawej strony Marii, w głębi, widoczna Trójca Św. Pod płaszczem Madonny rozmodlony dominikanin, drugi, zapewne św. Dominik, unosi się w chmurach w pozycji klęczącej. U dołu ogromny zastęp zakonników i zakonnic z rodziny dominikańskiej, a wśród nich dwóch papieży, wielu świętych, błogosławionych 
i świątobliwych. Między nimi św. Jacek, z swymi atrybutami ikonograficznymi, monstrancja w prawej i figura Matki Bożej w lewej ręce. XVIII w. Późnobarokowy.

B ibliografia: AKK, rkps 38: Inwentarz z r. 1839 s. 8v. - AKK, rkps 40: Inwentarz z r. 1875 s. 382 . - O. W. Now a kow ski: Pamiątka s. 28.

\section{2}

Męczeństwo bł. Agatanioła i Kasjana, kapucynów (beat. 1905), $97 \times 178 \mathrm{~cm}$, płótno, olej. Obaj kapucyni, jeden w pozycji stojącej, frontalnej, drugi w pozycji klęczącej, w aureolach, skrępowani łańcuchami, otoczeni przez uzbrojonych Abisyńczyków. Tło zielonopopielate i czerwone. Malował o. Florian Janocha $w$ r. 1905.

Bibliografia: AKK, rkps HCC, III s. 343. - Lex. cap. szp. 20, 361.

83

Chrystus cierpiący z Matka Bożą, $93 \times 90 \mathrm{~cm}$, płótno, olej. W owalu popiersie Chrystusa, en face, $\mathrm{z}$ korona cierniową na głowie, $\mathrm{z}$ palmą męczeńską $w$ prawej ręce, $w$ białej szacie. $Z$ lewej u dołu, Matka Boża, w profilu prawym, $z$ lewą ręką wzniesioną $w$ górę, $w$ niebieskiej szacie. Tło ciemne. XVIII w. Późnobarokowy.

Bibliografia: AKK, rkps 40: Inwentarz z r. 1875 s. 114.

\section{4}

Sw. Józef, $78 \times 98 \mathrm{~cm}$, płótno, olej. W pozycji stojacej, frontalnej, w fioletowej szacie i różowym płaszczu, z Dzieciątliem Jezus na prawej ręce. $\mathrm{Z}$ lewej, u dołu, dwa białe gołąbki, z prawej róże i drzewo. W perspektywie zielona łąka i fragment żóltych domów miasta na tle gór. Tło zielononiebieskie i żólte. II poł. XIX w.

\section{5}

Matka Boża, $38 \times 48 \mathrm{~cm}$, płótno, olej. Fopiersie, twarz trzy czwarte w lewo, ręce złożone do modlitwy, w białej chustce i niebieskim płaszczu. Jasnożółta aureola wokoło głowy. Tło zielonoszare. Obraz znajdowal się zawsze nad pulpitem w chórze. Obecnie przeniesiony do oratorium na I piętro. I poł. XVIII w. Późnobarokowy.

Bibliografia: AKK, rkps 38: Inwentarz z r. 1839 k. 6. - AKK, rkps 40: Inwentarz z r. 1875 s. 118.

86

Sw. Jan Sarkander, $85 \times 129,5 \mathrm{~cm}$, płótno, olej. W pozycji klęczącej, w czarnym habicie i białym płaszczu; w wyciągniętej prawej ręce dzierży lrrzyż, lewa złożona na sercu. Przed pulpitem nalkrytym połą plaszcza otwarta księga. $Z$ obu stron aniolowie obejmują świętego, ponad nim aniołki unoszą biała lilię. Tło brązowe. I poł. XVIII w. Późnobarokowy.

87

Matka Boska Bolesna, $76 \times 105 \mathrm{~cm}$, płótno, olej. Twarz trzy czwarte w prawo, prawa ręka na sercu, w niebieskiej sukni i czerwonym płaszczu. $\mathrm{Z}$ obu stron aniołowie. Tło ciemne. I poł. XVIII w. Późnobarokowy.

Bibli ografia: AKK, rkps 40: Inwentarz z r. 1875 s. 114 . - O. W. Nowa kow ski: Pamiątka s. 29. 
Św. Franciszek w ekstazie, $112 \times 85 \mathrm{~cm}$, płótno, olej. W pozycji klęczącej przed krzyżem, $z$ twarzą trzy czwarte w prawo, prawą rękę wspiera o policzek, w lewej trzyma czaszke. Tło ciemnobrazowe. Na odwrocie napis: „Hier. Mariano n. 1528, † 1592. Podhorce". Jest to zapewne kopia z wcześniejszego obrazu. II pol. XVIII w.

B ibliografia: AKK, rkps 40: Inwentarz z r. 1875 s. 382.

\section{9}

Św. Wojciech, $87 \times 118 \mathrm{~cm}$, płótno, olej. W pozycji frontalnej, z twarzą trzy czwarte w prawo, w żóltej kapie, białej infule i białym paliuszu z czarnymi krzyżykami. W prawej ręce trzyma podwójny, arcybiskupi krzyż i wiosło - atrybut ikonograficzny, lewa spoczywa na sercu. W górnej części obrazu napis: „S[anctus] Adalbertus Episcopus et M[arty]r”. XIX w. Późnobarokowy.

\section{0}

Naigrawanie z Chrystusa, $87,5 \times 107 \mathrm{~cm}$, płótno, olej. Pan Jezus w pozycji frontalnej, $\mathrm{z}$ twarzą trzy czwarte $\mathrm{w}$ prawo, $\mathrm{z}$ czarną brodą, $\mathrm{z}$ koroną cierniowa, $z$ rękami skrępowanymi sznurem, $w$ aureoli. $Z$ ramion opada purpurowa szata. Z prawej nachylony ku Chrystusowi żołdak w helmie i pancerzu. Tło ściemnione. I pol. XVIII w. Późnobarokowy.

\section{1}

Portret nieznanego kapucyna, $82 \times 135 \mathrm{~cm}$, płótno, olej. Z twarzą trzy czwarte w lewo, z siwą brodą, z rękami złożonymi do modlitwy, w aureoli. Tło jasnobrązowe. XVIII w. Późnobarokowy.

\section{2}

Św. Ignacy z Laconi, kapucyn (beat. w r. 1940, kan. 1951), $76 \times 120 \mathrm{~cm}$, płótno, olej. W pozycji klęczącej, z siwą brodą, prawa ręka na sercu, lewa wyciąnnięta przed siebie. Przed nim, w górze, wizja Matki Bożej z Dzieciątkiem Jezus, w koronach, w jasnoźółtej światłości. Tło jasnoniebieskie i zólte. Sygn.: „Z. Rudzka. 1952”.

Bibliografia: AKK, rkps HCC, IV s. 412. - AKK, rkps HCC, IVa s. 79. 93

Św. Barbara, $81 \times 112 \mathrm{~cm}$, płótno, olej. W pozycji klęczącej, w żółtej sukni i czerwonym płaszczu, prawa ręka złożona na sercu, w lewej trzyma kielich z hostia. Nad nią Chrystus en face. Z prawej strony kilka aniołków. Czerwony płaszcz swiętej rozwinięty w powietrzu pięknymi fałdami. Tło brązowe. I pol. XVIII w. Późnobarokowy.

\section{4}

Św. Augustyn, $81 \times 136 \mathrm{~cm}$, druk tzw. ,teza” naklejona na płótno. Swięty z twarzą trzy czwarte w prawo, w pozycji siedzącej, przed otwartą księga $z$ napisem: "Initium sapientiae, timor Domini. Eccl. C. 1. V. 16". Przed nim dwaj aniołowie pomagają mu $w$ pisaniu. Poniżej powalona „Haeresis” ze swymi sojusznikami. Koniec XVIII w.

Uwaga: Obraz jest zawerniksowany i dlatego technika graficzna trudna do odcyfrowania. Może to być równieź mezzotinta.

B ibliog r afia: AKK, rkps 38: Inwentarz z r. 1839 k. 8. - AKK, rkps 40: Inwentarz z r. 1875 s. 118. 


\section{5}

Św. Józef, $63 \times 104 \mathrm{~cm}$, druk tzw. ,teza" naklejona na płótno. W pozycji frontalnej, z Dzieciątkiem Jezus na rękach, aureola wokoło głowy, w lewej ręce lilia. W górze napis: „Sanctus Josephus Nutritius Filii Dei Vivi”. W dole dedykacja Franciszkowi Modrzewskiemu, burgrabiemu krakowskiemu i pułkownikowi. W środku napisu herb Modrzewskiego. Sygn.: „Antonius Freindt sculp[sit] Olomu[cii]". Koniec XVIII w.

Uwaga - jak pod nr 94.

96

Adoracja Najświętszego Sakramentu przez aniołów, $60 \times 106 \mathrm{~cm}$, druk tzw. "teza" naklejona na płótno. W centrum obrazu monstrancja, wokoło adorujący aniołowie. U dołu dedykacja dla o. Nepomucena Wiktora, przeora paulinów na Skałce w Krakowie, z okazji egzaminu "de poenitentia". Sygn.: „Cum Privil[egio] Sac[rae] Caes[areael May[estatis]”. „G. B. Göz del[ineavit]”.

Bibliografia: Katalog zabytków sztuki w Polsce. T. 7: Województwo opolskie. Z. 9: Powiat nyski. Pod red. T. Chrzanowskiego i M. Korneckiego. Warszawa 1963 s. 202. Poza tym inwentarzem w żadnym dostępnym leksykonie nie figuruje nazwisko artysty.

97

Alegoria jubileuszowa, $90,5 \times 150 \mathrm{~cm}$, druk tzw. „teza" naklejona na płótnie. Nad Bazyliką Piotrową święci z Matką Najświętszą wyrażaja radość z okazji jubileuszu. Napisy głoszą, że łaska Boża zwycięża moce piekielne.

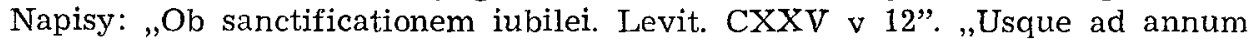
iubileum". „A bramy piekielne nie zwyciężą go". „Gratia victrix Jansen et Baii". XVIII w.

Uwaga $\rightarrow$ jak pod nr 94.

\section{8}

Wizja św. Antoniego z Padwy, $101 \times 186 \mathrm{~cm}$, płótno, olej. W pozycji frontalnej, twarz trzy czwarte w lewo, z Dzieciątkiem Jezus w prawej ręce na księdze, a w lewej biała lilia. Dzieciątko en face, z żółtą aureolą wokoło główki, $z$ prawą rączką podniesioną do błogosławienia. $Z$ lewej strony fragment pulpitu z leżącą księga. Z prawej, pızez okno, widoczny pejzaż. Płótno obciągnięte na grubej desce. XVIII w. Barok.

99

Adoracja Najświętszego Sakramentu przez ariołów, $60,5 \times 84 \mathrm{~cm}$, druk tzw. „teza" naklejona na płótnie. W centrum obraz owalny z Barankiem, ponad nim rokokowa monstrancja, adorowana dokoła przez aniołów. Jeden z nich, w dole, okadza monstrancję kadzielnicą. Sygn.: „Privil[egium] Sac[rae] Caes[areae] Cathollicae] Maj[estatis]”. „Gottlieb Heuss sculps[it] et excud[it] Aug[ustae] Vind[elicorum]". Koniec XVIII w. Rokoko.

Uwaga - jak pod nr 94.

B ibliografia: AKK, rkps 38: Inwentarz z r. 1839 k. 8. - Por. nr 96.

\section{0}

Św. Juda Tadeusz, $58 \times 70,5 \mathrm{~cm}$, płótno, olej. Twarz trzy czwarte w prawo, broda i włosy rude, opończa ciemnobrazowa. W prawej ręce trzyma atrybut ikonograficzny - grubą i wielką pałkę. I poł. XVIII w. Późnobarokowy. 


\section{1}

„Series chronologica ministrorum generalium Ordinis F. F[ratrum] Minorum Slanctil P[atris] Francisci Capuccinorum". Seria zawiera 58 miedziorytów o wym. $8 \times 12 \mathrm{~cm}$, naklejonych na płótnie o wym. $75 \times 110 \mathrm{~cm}$.

Opis pierwszego portretu: Sw. Franciszek $w$ owalu, en face, $w$ aureoli, w kapturze na głowie, w habicie kapucyńskim. Prawa ręka wzniesiona do błogosławienia, w lewej trzyma księge Ewangelii.

Ostatni portret: „F[rater] Nicolaus a S[ancto] Ioanne a Marignano”, mianowany generałem w $1859 \mathrm{r}$. Jest to $60 \mathrm{z}$ kolei generał zakonu.

Sygnatury prawdopodobnie obcięte przy naklejaniu portretów na płótno.

B ib li o grafia: AKK, rkps 40: Inwentarz z r. 1875 s. 386 . - Lex. cap. szp. 792-793:

\section{2}

I. „Iconographicus index concionatorum qui ex Ordine Capuccinorum assumpti in Apostolica Pontificis Maximi aula evangelizaverunt Sion". Seria zawiera 19 miedziorytów o wym. $8,5 \times 13 \mathrm{~cm}$ i jest naklejona na płótnie o wym. $139 \times 84 \mathrm{~cm}$.

Opis pierwszego portretu: O. Anzelm Marzati a Monopoli, ur. w r. 1557, mianowany kaznodzieją apostolskim 1594, kardynałem 1604, zmarł w r. 1607 . Popiersie $w$ owalu, $z$ brodą, twarz trzy czwarte $w$ prawo, $z$ biretem na glowie. $\mathrm{U}$ dołu podpis.

Ostatni portret: Fr[ater] Aloysius Puecher Passavalli a Trento, $1855 \mathrm{r}$.

Sygnatury prawdopodobnie obcięte przy naklełaniu portretów na płótno.

II. „Index Rever[endissimorum] Cardina[lium] Archi[episcoporum] et Episco[porum] ex Ordine S[ancti] P[atris] n[ostri] F[rancisci] Capucinorum". Seria zawiera 77 miedziorytów o wym. $8,5 \times 13 \mathrm{~cm}$ i jest naklejona na płótnie obok serii I.

Opis pierwszego portretu: O. Anzelm Marzati, w owalu, twarz trzy czwarte $w$ prawo, $z$ biretem na glowie, wskazującym palcem prawej ręki zaznacza cytat w księdze leżące j przed nim. W kardynalskim płaszczu. Poniżej owalu podpis.

Ostatni portret: Angelicus Bedenik a Koprivnica, w r. 1861 biskupem.

Bibliog r f i a: AKK, rkps 40: Inwentarz z r. 1875 s. 386. - Lex. cap. szp. 792-793. - Fr. Bonifazio da Nizza Capuccino: Ritratti degli uomini illustri dell' istituto de' Minori Capuccini promossi, o destinati dignità ecclesiastiche. Vol. 1-2. Roma 1804. Zawiera 52 miedzioryty. Biografia bpa A. Przedwojewskiego $w$ t. 1 s. 85-86, miedzioryt $\mathrm{nr}$ 30. - Michelangelo da Rossiglione: Cenni biografici e ritratti di padri illustri dell' Ordine Cappuccino sublimati alle dignità ecclesiastiche. Vol. 1-3. Roma 1850. Biografia bpa A. Przedwojewskiego w t. 1 s. 101 , miedzioryt nr 27.

\section{3}

"Patres Ordinis Capucinorum qui virtutibus let] sanctitat[el floruerunt" Sería zawiera 33 miedzioryty o wym. $8 \times 12 \mathrm{~cm}$ i jest naklejona na plótnie o wym. $65 \times 68,5 \mathrm{~cm}$.

Opis pierwszego portretu: Józef Maria Bentivoglio z Bolonii, zm. 1698. Popiersie $w$ owalu, $z$ siwą brodą, prawa ręka spoczywa na czaszce, w lewej skrypt, przed nim krzyż. Poniżej owalu napis.

Ostatni portret: Jesualdus a Reggio Calabria, zm. 1803.

Sygnatury prawdopodobnie obcięte przy naklejaniu portretów na płótno.

B ibli og rafia: AKK, rkps 40: Inwentarz z r. 1875 s. 386. - Lex. cap. szp. $792-793$. 


\section{4}

Sw. Juda Tadeusz, $68 \times 92 \mathrm{~cm}$, druk tzw. „teza" naklejona na płótno. En face, prawą ręką wskazuje na prostokątny obraz $w$ ramkach $z$ wizerunkiem Zbawiciela, który podtrzymuje z lewej, u dołu, anioł; w lewej ręce trzyma męczeńską pałkę. Płaszcz świętego rozwiewa siẹ w powietrzu. Powyzej widoczny barokowy aniolek. Koniec XVIII w. Rokoko.

Uwaga — jak pod nr 94.

\section{5}

Św. Jan Kanty ze św. Barbarą, $87 \times 112 \mathrm{~cm}$, płótno, olej. W centrum, w pozycji frontalnej, stoi św. Jan Kanty (?), z rękami złożonymi, w niebieskiej todze z purpurową podszewką. Z prawej św. Barbara $z$ koroną na głowie, $z$ płonącym sercem w lewej ręce, w niebieskiej sukni i czerwonyn płaszczu rozwiewającym się $w$ powietrzu. $Z$ lewej strony święty z krzyżem w lewej ręce. Obraz ściemniony. I poł. XVIII w. Barok.

Bibliografia: AKK, rkps 40: Inwentarz z r. 1875 s. 382.

106

Św. Kajetan, $62 \times 87 \mathrm{~cm}$, plótno, olej. Z lewej św. Kajetan, w pozycji klęczącej, w czarnym habicie teatynów, przyjmuje z rąk Matki Bożej Dzieciątko Jezus owinięte $\mathrm{w}$ białe pieluszki. Wizja w żóltopopielatych chmurach na tle niebieskim. Jest to fragment $\mathrm{z}$ obrazu oltarzowego $\mathrm{z}$ kościoła OO. Kapucynów w Krakowie. Malował Pietro Dandini w r. 1701. Obraz kosztował 75 imperiałów.

Bibliografia: AKK, rkps HCC, I 8, 27-28. - AKK, rkps 40: Inwentarz z r. 1875 s. 114 . - APK, rkps - O. K. G a d a cz: Historia klasztoru s. 11, 22. Bibl. Un. Warsz., rkps sygn. 35: Annales Provinciae Polonae k. 96-97. M. Skrudlik: O klasztorze OO. Kapucynów w Krakowie. - E. C h w a lewik: Zbiory polskie. T. 1 s. 221. - M. Skrud 1ik: Królowa Korony Polskiej s. 302303. Autor pomylił się uważając obecny obraz ołtarzowy Orłowskiego ( $\mathrm{nr}$ 21) za dzieło Dandiniego, dlatego jego uwagi mogą odnosić się tylko do obrazu Orłowskiego.

\section{7}

Swięty kapucyn, $82,5 \times 112 \mathrm{~cm}$, plótno, olej. W pozycji klęczącej, wokoło głowy aureola, w obu rękach trzyma krzyż. Z lewej, w górze, tło jasne, które oświetla wyraziście twarz świętego, zatopionego w kontemplacji. XVIII w.

\section{8}

Portret ks. prałata Michała Sołtyka, $70 \times 91 \mathrm{~cm}$, płótno, olej. W pozycji siedzącej, na fotelu z purpurowym obiciem, z twarzą lekko zwróconą w prawo, o siwych włosach, w granatowym ubiorze, w rękach trzyma otwartą księgę. Z lewej u dołu płótno rozdarte, a u góry farba wytarta. Malował prawdopodobnie Jan Chrzciciel Lampi. Klasztor otrzymał portret w r. 1830.

B ibliografia: AKK, rkps 38: Inwentarz z r. 1839 k. 7v. - AKK, rkps 39: Inwentarz z r. 1821 k. 40. - AKK, rkps 40: Inwentarz z r. 1875 s. $386 . \longrightarrow$ O. W. Now ak owski: Pamiątka s. 31. - M. Skrudlik: O klasztorze OO. Kapucynów w Krakowie. - E. Chwalewik: Zbiory polskie. T. 1 s. 222. Ks. J. Wiśnie wski: Katalog prałatów i kanoników sandomierskich od 11861926 r. tudzież sesje kapituły sandomierskiej od 1581 do 1866 r. Radom 1926 s. $276-277$.

Madonna z Dzieciątkiem, $70 \times 92 \mathrm{~cm}$, płótno, olej. Matka Boska z twarzą trzy czwarte w lewo, z Dzieciatkiem Jezus w białej sukience na lewej rece. 
Dzieciątko złożyło prawą rączkę na sercu. Z lewej, w dole, kobieta z kolczykiem w uchu, z prawą ręką wyciągniętą ku Dziecięciu, składa prawdopodobnie dar. Tło ściemnione. XVIII w. Barok.

\section{0}

Ukrzyżowanie, $102 \times 147,5 \mathrm{~cm}$, płótno, olej. W centrum Chrystus na krzyżu. Z lewej strony klęczy święty, w aureoli, z lewą ręką na sercu, w czerwonej szacie i czarnym płaszczu. Pod nim, u dołu, klęczą trzy niewiasty $\mathrm{w}$ aureolach. $Z$ prawej strony krzyża, święta $\mathrm{w}$ aureoli, w czerwonej szacie i białej chustce, ociera chustą płynące łzy, a lewą ręką obejmuje krzyż. Za nią z prawej klęczy fundator (?) z rękami złożonymi do modlitwy i owiniętymi różańcem, w ciemnym ubraniu, wpatrzony w krzyż. Tło ciemne. XVII w. Barok.

\section{1}

Dysputa teologiczna, $85,5 \times 108 \mathrm{~cm}$, druk tzw. ,teza” naklejona na płótnie. $\mathrm{Na}$ oltarzu monstrancja, $\mathrm{z}$ obu stron zapalone świece, ponad nią dwaj aniołowie trzymaja otwartą księge z napisami: „Figura legis naturae”, „Figura Vetleris] Test[amenti]”, „Promissio", „Solutio" itd. Z obu stron oltarza klęczą lub stoją doktorzy Kościoła. Z prawej św. Ambroży, w biskupich szatach; niżej św. Augustyn z gęsim piórem; z lewej św. Hieronim i św. Grzegorz, w biskupich szatach. Poniżej dedykacja dla Tadeusza Gniewosza z Oleksowa. W środku dedykacji herby Rawicz i Ostoja. Sygn.: „G[eorgius] P[hilippus] et Christ[ianus] Regendas Pater et Filius sculps[erunt] et excud[erunt] Aug[ustae] Vind[elicorum]". Koniec XVIII w. Rokoko.

Uwaga - jak pod $\mathrm{nr} 94$.

Bibliografia: AKK, rkps 40: Inwentarz z r. 1875 s. 386.

\section{2}

Św. Rodzina, $71,5 \times 114 \mathrm{~cm}$, druk. tzw. ,teza" naklejona na plótnie. W rokokowej ramce, na pierwszym planie, Matka Boża, en face, z dziewięcioma gwiazdami wokoło głowy, $z$ Jezusem $z$ prawej strony. $Z$ lewej, stoi św. Józef, en face, z aureolą wokoło głowy. Z prawej strony Jezusa widoczny może św. Jan Chrzciciel. Ponad grupa, z prawej, Bóg Ojciec prawą ręką wskazuje Ducha Św. (w postaci gołębicy), od którego promienie łaski spływają na Jezusa i Marię. Sygn.: „Alexander Marchesini pin[xit]". „Christian Rugendas excudit Aug[ustae] Vindlelicorum]". Poniżej dedykacja dla Józefa Sadowskiego, opata tynieckiego, z okazji zakończenia egzaminu z teologii.

Uwaga - jak pod nr 94.

Bibliografia: AKK, rkps 40: Inwentarz z r. 1875 s. 116.

\section{3}

Niepokalanie Poczęta w otoczeniu aniołów, $93 \times 140,5 \mathrm{~cm}$, płótno, olej. Kopia Murilla. Madonna w pozycji frontalnej, stojącej, z rękami złożonymí do modlitwy, w białej sukni i błękitnym płaszczu. Stoi na księżycu. U góry i w dole widoczne uskrzydlone główki aniołków. II poł. XVIII w.

\section{4}

Pan Jezus pokazujący rany rạk, $51 \times 62 \mathrm{~cm}$, płótno, olej. Popiersie, głowa trzy czwarte w lewo, wlosy blond, oczy wzniesione w górę, biały płaszcz przewieszony przez lewe ramię. Obydwie dłonie wyciągnięte przed siebie. Aureola zarysowana delikatna linią. U dołu farby z gruntem odpadły. 
Skropiony wapnem. Sygn. na odwrocie płótna: „M. Rogowski m[alował] [1]865".

115

Apoteoza króla Jana III Sobieskiego, $44 \times 60 \mathrm{~cm}$, miedzioryt nalepiony na desce. Sobieski na koniu, w pancerzu i hełmie, delia rozwiewa sie z ramion, w prawej ręce buzdygan. Koń wspiera się na tylnych nogach, depcąc sztandar turecki, kopię i tarczę. W górze Sława z tarczą, na trąbce ogłasza zwycięstwo. Na dalszym planie katedra św. Szczepana w Wiedniu, a ponizej husaria uderza na broniących się Turków. Ponizej napis: „Joannes III D[ei] G[ratial Rex Poloniae Magnus Dux Lithuaniae, Russiae, Prussiae, Masoviae Sa[mogitiae] Exercituum Christianorum ad Viennam contra Turcos et Tartacos Ductor ac Triumphator Gloriosissmus". Sygn. z lewej strony: „Humill[imus] subditus Eleuter invenit et delineavit”. Z prawej: „C[harles] de la Haye sculp[sit] et excudit Varsaviae". Sztychowany w r. 1692.

Bibliografia: Rastawiecki: Slownik malarzów polskich, s. 158 . E. R a s t awi e cki: Słownik rytowników polskich tudzież obcych w Polsce osiadłych lub czasowo w niej przebywających. Poznań 1886 s. 124.

\section{6}

B1. Anioł z Akry, kapucyn (beat. 1825), 42,5 $\times 47 \mathrm{~cm}$, miedzioryt. Z lewe] strony błogosławiony, boso, w habicie kapucyńskim, niesie krzyż na swych barkach; za nim dwaj księza niosą podobne krzyże. W centrum mężczyźni kopią doły pod ustawienie misyjnych krzyży. Z prawej grupa kobiet na tle drzewa. W dali, na horyzoncie, widoczne trzy jaśniejące krzyze, które ukazały się w czasie misji św., prowadzonych przez błogosławionego. Poniźej podpis: „B[eatus] Angelus ab Acrio. Dum sacra missione absoluta Crucem sibi suo more bajulat, et eam constans facti monumentum sisteret, tres in aera fulgentissimae Cruces visae sunt, universo populo perclamante et obstupente". Sygn.: „Franclesco] Manno inv. e dipl.” Alessandro Mochetti inc. I poł. XIX w.

B ibliografia: AKK, rkps 38: Inwentarz z r. 1839 k. 9.

\section{7}

Niepokalanie Poczęta Opiekunka Zakonu Kapucyńskiego, 68,5 X104 cm, płótno, olej. Madonna w pozycji frontalnej, stojącej, z aureolą i dwunastoma gwiazdami wokoło głowy, w czerwonej sukni i niebieskim płaszczu. Rozłożone - szeroko ręce składa na głowach klęczących z obu stron kapucynów. W górze, z prawej strony, oko Opatrzności, z lewej serce z krzyżem na skrzyżowanych dwóch dłoniach i stopach. Tło brązowe. Obraz zniszczony, podziurawiony i. podarty. U dołu zatarty napis: „Bleata] V[irgo] Maria sub mysterio Immaculatae Conceptionis in Protectricem totius Ord[inis] F[ratrum] Minlorum] SLancti] P[atris] Francisci Capuccinorum approbante id Sede Apostolica" [...] dalej tekst nieczytelny I poł. XVIII w. Barok.

Bibliografia: AKK, rkps 38: Inwentarz z r. 1839 k. $8 \mathrm{v}$.

\section{8}

Alegoria sławy, $52 \times 39,5 \mathrm{~cm}$, miedzioryt. Na wozie triumfalnym, zaprząniętym w dwa lwy, siedzi Sława ze skrzydłami i trąbiąc wieści zwycięstwo, wspierając lewą stopę na martwej śmierci, leżącej u jej stóp. Na czele pochodu ze sztandarem postępuje bogini wojny Bellona, dalej szereg sławnych kobiet $\mathrm{w}$ historii. Za wozem widać $\mathrm{m}$. in. Aleksandra Wielkiego, Platona, filozofów greckich i rzymskich. Z lewej, w dali, przedstawiciele różnych 
narodów, $z$ prawej starożytne miasto na tle licznych drzew. Poniżej napis: „Famae triumphus a Francisco Petrarca primum excogitatus, et fuso carmine eleganter descriptus, in quo compressa morte, suscitatisque virtutibus liberales | artes subjiciuntur, tum illustres bello, et pace viri, tum Latinae, et Graecae commendatiores Heroinae, quarum unaqueque suis est distincta nominibus, ex vetusto / celeberrimi Titiani Archetypo, quod extat in Aedibus D. Ioannis Michilli Conductoris Generalis Pulveris Nicosiani, et Aque Vitis Status Pontificii'. Naklejony na deskę. I poł. XVIII w. Sygn.: "Titianus pinxit”. „Jo[annes] Ant[onius] Buti delfineavit]”. „Silvester Pomarede sculpsit Romae. Anno Jubilaei 1750".

Bibli ografia: AKK, rkps 38: Inwentarz z r. 1839 k. 9.

119

Alegoria śmierci, $52 \times 39 \mathrm{~cm}$, miedzioryt naklejony na deskę. Karawan śmierci zaprzężony w dwa woły, skierowany w lewo. $\mathrm{Na}$ wozie dwie kobiety, parka - Atropos i jedna z mojr - Lachesis, a nad nimi siedzi śmierć z kosą. Wokoło wozu leżą powalone sławne postacie kobiet i mężczyzn $\mathrm{m}$. in. Aleksander Wielki, w drgawkach śmiertelnych. Wóz śmierci niszczy wszystkich, papieży, cẹsarzy, królów, sławnych i prostych ludzi. Poniżej napis: „Triumphus mortis a Francisco Petrarcha versibus elegantissime scriptus, atque in Archetipa Titiani celeberrimi Pictoris tabula | quae Domini Ioannis Michilli Roseri iuris est, vitia coloribus ad artis miraculum expressus, huic aeri incisus apparet. Fila hominum vitae nostris cito currite fusis. = Dixerunt stabili fatorum numine Parcae Clotho, Atropos, Lachesis, MORS namque agit alta triumphum". Syng.: "Titianus pinxit". „Jo[annes] Ant[onius] Buti del[ineavit]". „Sylv[ester] Pomarede sculp[sit]”. I pol. XVIII w.

Bibliografia: AKK, rkps 38: Inwentarz z r. 1839 k. 9.

120

Alegoria czasu, $52 \times 39,5 \mathrm{~cm}$, miedzioryt naklejony na deskę. Na wozie, zaprzęgniętym w dwie łanie, skierowanym w lewo, jedzie Chronos ze skrzydłami, z długą siwą brodą i cyrklem, którym na dużej kuli ziemskiej wytycza lata. Wokoło wozu grupa sławnych osób z historii m. in. Kleopatra, Ulisses, Nestor i inni, postępują za wozem czasu. Na lewo fragment miasta, z prawej góry. Poniżej napis: „Ex Archetypo celeberrimi Titiani, quod sui juris est exprimi mandavit Dominus Joannes Michilli | Generalis Vectigalium Conductor pro Tabacco Romae in suis aedibus Anno 1748". Sygn.: "Titianus pinxit". „Jolannes] Anto[nius] Ruti (?) delin[eavit]". „Silvester Pomarede incidit".

Bibliografia: AKK, rkps 38: Inwentarz z r. 1839 k. 9.

121

Powrót rycerza do rodziny, $62 \times 49 \mathrm{~cm}$, litografia kredowa. Z prawe] strony, na fotelu siedzi ojciec rodziny, w żupanie i kontuszu; za nim zapewne jego zona, w czarnym czepku, przy krosnach. W środku sceny, żona rycerza z dwoma synkami. Za nimi zakonnik z prawą ręką wzniesioną do blogosławienia. $Z$ lewej, na fotelu, odpoczywa rycerz w częściowym pancerzu, $z$ buńczukiem $w$ ręce, a za nim giermek $z$ mieczem. W komnacie, na ścianie obraz Matki Bozej, militaria i antyczny zegar. XIX w.

\section{2}

Posłowie u króla Jana III Sobieskiego, $58 \times 43 \mathrm{~cm}$, litografia kredowa. $\mathrm{Z}$ prawej strony pod baldachimem król Sobieski, w kontuszu i szubie, z sza- 
blą w lewej ręce. Marysieńka siedzi na tronie, z lewej strony króla, a z prawej syn królewski; obok pacholę trzyma na poduszce królewską koronę. W głębi widoczny teolog królewski, kapucyn. Z lewej posłowie zagraniczni; jeden z nich klęczy na jednym kolanie przed królem; za nim stoi duchowny oraz kilku panów. XIX w.

\section{3}

Portret papieża Piusa VII, 46,5 $\times 62 \mathrm{~cm}$, płótno, olej. Papież w pozycji siedzącej, na purpurowym tronie, $z$ purpurowym podwyższeniem i takim zapleckiem; w białej szacie, purpurowej pelerynie i piusce. Prawa ręka wzniesiona do błogosławienia. I poł. XIX w.

Bibliografia: AKK, rkps 38: Inwentarz z r. 1839 k. 9.

\section{4}

Omdlenie św. Franciszka, $68 \times 79,5 \mathrm{~cm}$, blacha, olej. Swięty w pozycji klęczącej, w habicie kapucyńskim, $z$ rozłożonymi rękami. Podtrzymują go $\mathrm{z}$ obu stron aniołowie. Ponad grupa aniołek gra na skrzypcach. Z lewej strony na glazie skalnym czaszka. Tło ciemne. Obraz jest ilustracja do jednej ze scen z „Kwiatków św. Franciszka”. Jest to, zdaniem Skrudlika, zmodyfikowana kopia obrazu znajdującego się $\mathrm{w}$ kościele bernardyńskim w Leżajsku. Malowana na podstawie nieznanej ryciny. Autor umieścił w kompozycji obrazu aniołów na podobieństwo „Wizji św. Augustyna” van Dycka, a św. Franciszka usytuował odwrotnie niż to jest w obrazie leżajskim. XVII w. Barok.

B i b li og r a f i a: AKK, rkps 40: Inwentarz z r. 1875 s. 116. - O. W. Now akowski: Pamiątka s. 24-25. - M. Skrudlik: Sw. Franciszek Seraficki s. $165-169$.

\section{5}

Kapucyni spieszący na jutrznię, $70 \times 55,5 \mathrm{~cm}$, płótno, olej. $\mathrm{Na}$ tle jasnobrązowego korytarza klasztornego, kapucyni w kapturach, w brązowych habitach, idą dwójkami w lewo. Na czele kroczy zakonnik z siwą brodą, z zapalonym kagankiem $w$ prawej ręce, za nim pozostali ojcowie $z$ brewiarzami w rękach. Posadzka wyłożona cegłami. Na korytarzu zegar, którego wskazówka dochodzi do 12 godz. w nocy. I poł. XIX w.

\section{6}

Madonna adorująca Dzieciątko Jezus, $120 \times 95 \mathrm{~cm}$, plótno, olej. Matka Boża pochylona nad Dzieciątkiem, z rękami złożonymi do modlitwy, z wyrazem zadumania i głębokiej kontemplacji. W białej chustce i niebieskiej sukni. I pol. XIX w.

\section{7}

Pogrzeb kapucyna, $98 \times 72 \mathrm{~cm}$, płótno, olej. W centrum mary ze znıarłym zakonnikiem. Na ołtarzu zapalone świece. Od oltarza celebrans w komży i. stule wygłasza żałobną mowę. $Z$ obu stron ołtarza ministranci. Za trumną pod oknem zakonnik $z$ krzyzem w rekach, a za nim zakonnicy z zapalonymi świecami. Swiatło słoneczne poprzez okno oświetla całą scenę. Na odwrocie plótna napis: „Association d'un frère mort aux Capucins par Chialli - copié par Louis Pisani. Gallerie de Tableaux de Louis Pisani, 37 Borgognissanti second étage - Florence". Kopia z II pol. XIX w. Oryginał namalował Vincenzo Chialli w I poł. XIX w. Dnia 18 marca 1947 r. 
obraz ten kupil od nieznanej pani, za 4.000 zk, o. Alojzy Wojnar, gwardian klasztoru.

B ibliografia: APK, rkps - Br. E. Chmiel: Kronika s. 154. - Thiem e u. B e c ker, VI 481-482. - Bénézit, II 483: „Messa cantata et Esequie d'un Cappuccino, conservés à l'Academie de Florence". - N a gle r, II 516.

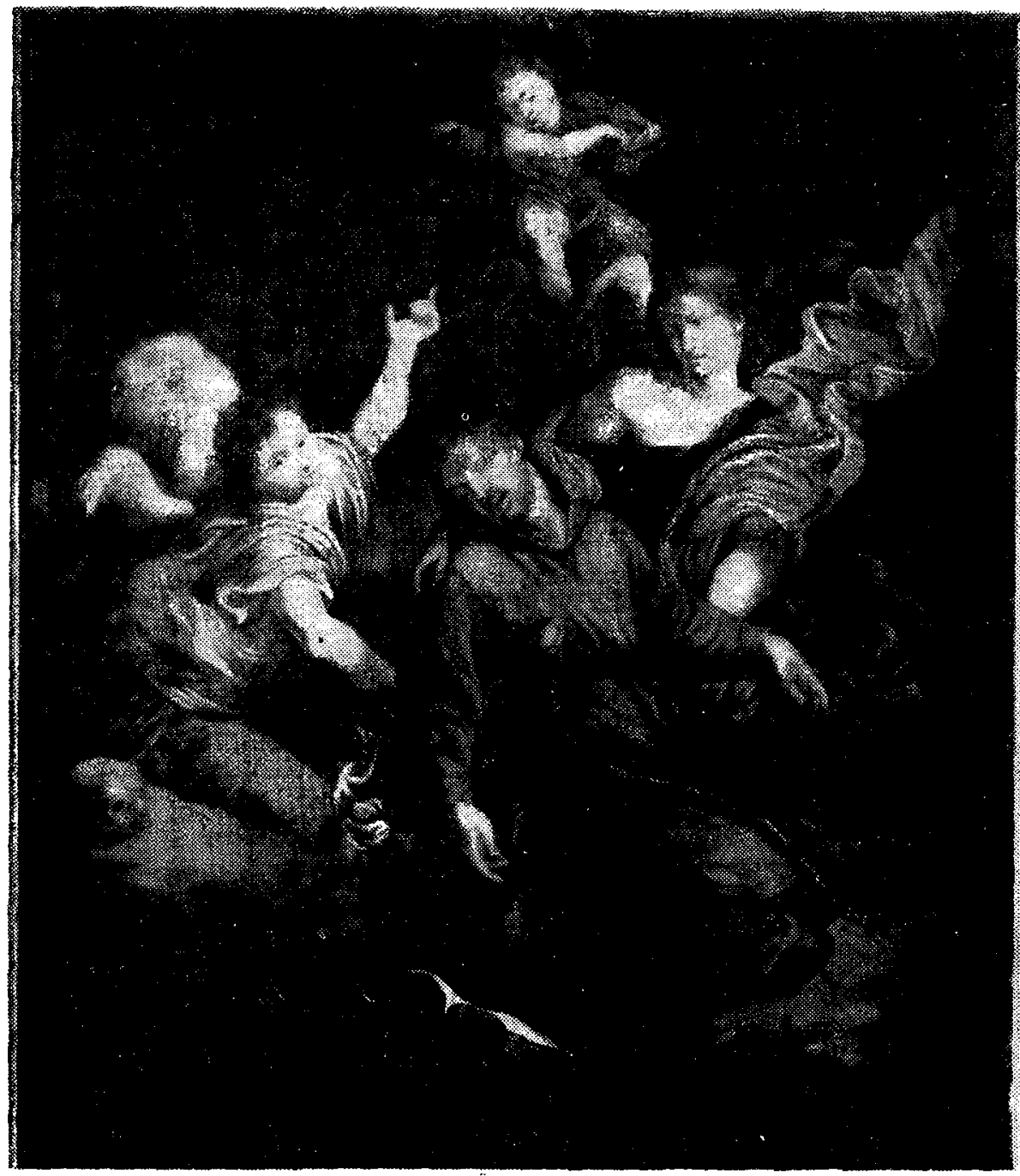

Omdlenie św. Franciszka (124)

\section{8}

Chór zakonny w rzymskim klasztorze Kapucynów na placu Barberini, $81,5 \times 99,5 \mathrm{~cm}$, płótno, olej. Okno w tylnej ścianie oświetla jasno chór zakonny. Na ścianach liczne obrazy, w górze zawieszona chorągiew z wizerunkiem Matki Bożej. Stalle zapełnione zakonnikami. W środku pulpit, zwień- 
czony krzyżem; na pulpicie duzy psałterz. W środku chóru celebrans w kapie, $\mathrm{w}$ asyście dwóch braci w komżach i ministranta $\mathrm{z}$ woda święconą dokonuje aspersji. Na pierwszym planie kot, wpatrzony $w$ celebransa. $Z$ prawej nieznany mężczyzna, $w$ zółtych spodniach, niebieskim płaszczu, z teką pod pacha i cylindrem $w$ lewej ręce. Na odwrocie napis: „Staraniem JM. X. Leona Dolińskiego Gwardyana OO. Kapucynów w Krakowie 1890 r.” Sygn.: „Józef Zajączkowski malowal". Jest to kopia obrazu wykonanego przez malarza Granet-Campanella w r. 1852. Oryginał znajduje się w muzeum miasta Königsberg. W oryginale brak męzczyzny $z$ cylindrem.

Bibliografia: Melchior a Pobladura OFM Cap.: Historia generalis Ordinis Fratrum Minorum Capuccinorum. Pars 2. Vol. 1. Romae 1948 s. 109.

\section{9}

Oblicze Chrystusa na chuście św. Weroniki, $69 \times 86,5 \mathrm{~cm}$, płótno, olej. Oblicze prawdopodobnie papierowe, z twarzą Chrystusa i długimi włosami, nalepione na białej chuście, której frędzle widoczne u dołu. W dole przez farbę przebija napis, może $\mathrm{z}$ zamalowanego płótna. Płótno nalepione na dyktę, która po bolkach została zamalowana. XIX w.

Portret ks. Antoniego Walczyńskiego († 1837), $55 \times 68 \mathrm{~cm}$, płótno, olej. En face, w białej komzy i czerwonym mucecie, na piersiach dystynktorium kanonickie (złoty lanicuch $\mathrm{z}$ orłem polskim). W prawej ręce brewiarz. Na odwrocie napis: „X. Antoni Walczyński. Slwiętej] T[eologii] Dr. Kanonik Katedralny Krakowski i Kollegiaty Kieleckiey Rzeczypospolitey Krakowski Senator". (Zmarł 1837 r.) Sygn. na odwrocie: „Józef Brodowski pinx[it]. 1833”.

Bibliografia: AKK, rkps HCC, II s. 9. - Ks. L. Eęt owski: Katalog biskupów, prałatów i kanoników krakowskich. T. 4. Kraków 1853 s. 195.

\section{1}

Portret Piotra Dembińskiego, stolnika waleckiego, $66 \times 68 \mathrm{~cm}$, płótno, olej. Popiersie w pancerzu, tło ciemne. Koniec XVIII w. Późnobarokowy.

Bibliog rafia: AKK, rkps HCC, I s. 356. - AKK, rkps 46: Sepulti in ecclesia nostra saeculares s. 10. Piotr Dembiński z rodziny fundatora klasztoru krakowskiego, „dapifex Wałecensis" został pochowany w krypcie fundatorów dnia 15 października 1815.

\section{2}

Portret ks. Józefa Alojzego Putanowicza, $54 \times 62 \mathrm{~cm}$, płótno, olej. Popiersie, zwrócone lekko w lewo, o czarnych włosach, w białej todze i niebieskim mucecie; na piersiach złoty łańcuch $z$ dystynktorium $w$ prawej ręce brewiarz. Z lewej strony u góry napis: „M. Josephus | Putanowicz| S[acrae] Theologiae] D[octor] et P[rofessor] Sacri Collegii Theologici / Praeses Primus | 1780 - Confr[ater] O[rdinis] Cap[ucinorum] Adse[nsus] | Laur[entius] a Brundusio / Voluit nominari. Istius Divi / Beatificatione | Cracloviae] Celebrata | Obiit Anno| 1788 - D[ie] 11 Febr[uarii]". II pol. XVIII w. Późnobarokowy.

Bibliografia: AKK, rkps HCC, I s. 216-218. - AKK, rkps 38: Inwentarz z r. 1839 k. 9. - O. W. Now a k ow ski: Pamiątka s. 30. - J. M y cie $1 \mathrm{ski:}$ Katalog portretów i obrazów będących własnością Uniwersytetu Jagiellońskiego. Kraków 1913 s. $14 \mathrm{nr} 68$. - J. P a choń s ki: Drukarze, księgarze i bibliofile krakowscy. 1750-1815. Kraków 1962 s. 106 (reprodukcja repliki portretu ze zbiorów UJ). 


\section{3}

Portret ks. Walentego Pruskiego, $52 \times 76 \mathrm{~cm}$, płótno, olej. Popiersie lekko zwrócone w lewo, w siwej peruce, w białej komzy i purpurowym mucecie, $\mathrm{z}$ dystynktorium kanonickim (złoty łańcuch $\mathrm{z}$ orłem) na piersiach. Poniżej napis: „Valentinus Pruski Canonicus Cathed[rae] Cracovliensis] | Pater Pauperum et hujus Conventus / Singularissimus Benefactor obiit 2 Febru[arii]. Anno 1798". II poł. XVIII w. Późnobarokowy.

Bibliografia: AKK, rkps 38: Inwentarz z r. 1839 k. 9. - O. W. Nowakowski: Pamiątka s. 27. - Ks. Eçtowski: Katalog III s. 500-501.

134

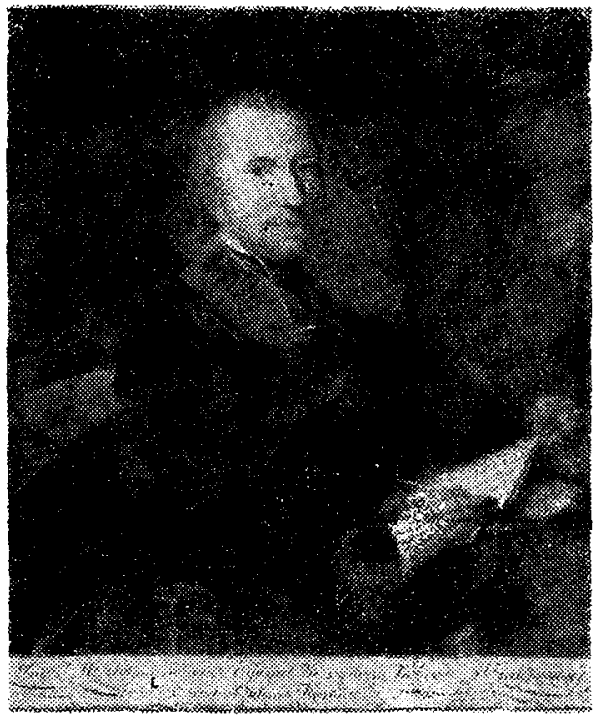

Portret hr. Pawła Soltyka, $81 X$ $97 \mathrm{~cm}$, płótno, olej. W pozycji siedzacej, na purpurowym fotelu, w ciemnym ubraniu, $z$ niebieska szarfą i kanonickim dystynktorium na piersiach. Poniżej na białym tle napis: „Pawel Hr. Soltyk, Officyał Konsystorza Kollegiaty Sandomi[e]rskiej, wielu orderów Kawaler". Malowal Jan Chrzciciel Lampi. II poł. XVIII w. Późnobarokowy.

B ibliog r afia: AKK, rkps 38: Inwentarz z r. 1839 k. 7v. - AKK, rkps 40: Inwentarz z r. 1875 s. $386 .-$ $\mathrm{R}$ a s t awie cki: Slownik malarzów polskich, I s. 254. - O. W N ow ak ow ski: Pamiątka s. 31. - M. S k r ud lik: O klasztorze OO. Kapucynów w Krakowie. - E. C $\mathrm{Ch}$ a l e wi k: Zbiory polskie. T. 1 s. 222.

135

Portret ks. prymasa Michała Poniatowskiego, $53 \times 63,5 \mathrm{~cm}$, płótno, olej. Popiersie z siwymi włosami, w purpurowym mucecie, $z$ niebieską szarfą a na niej złoty łańcuch $z$ krzyżem i orderem Orła Białego na piersiach; z lewej gwiazda orderowa. Pod szyja dwie czarne wypustki. II poł. XVIII w. Późnobarokowy.

Bibliografia: AKK, rkps 38: Inwentarz z r. 1839 k. 9. - Ks. J. Korytkowski: Arcybiskupi gnieźnieńscy, prymasowie i metropolici polscy od roku 1000 aż do roku 1821 [...] T. 5, Poznań 1892 s. 151-214.

\section{6}

Portret Antoniego Wolfa, $70 \times 87,5 \mathrm{~cm}$, płótno, olej. W pozycji siedzącej, z siwymi włosami, w czarnym mundurze ze złotymi guzikami, w białym szalu. $W$ prawej ręce trzyma rozpieczętowany list, obok z lewej, na białym blacie lézy rozdarta koperta z przelamana pieczęcią lakową. Podpis pod portretem: "Franciszek Antoni Wolff de Wolfsthal". Na odwrocie napis: "In matura aetate depictus, in bona senectute mortuus, | Die 3 Xbris 1818. I Sepultus in Ecclesia Villae Przemykow Bonorum suarum haereditaria. Requiescat | in pace. Amen". U dołu odpadł grunt z farbą. II poł. XVIII w. Późnobarokowy.

Bibliografia: AKK, rkps 38: Inwentarz z r. 1839 k. 9. 
137

Portret nieznanego kanonika, $47 \times 60 \mathrm{~cm}$, płótno, olej. Popiersie en face, z czarnymi włosami $\mathrm{z}$ przedziałem $\mathrm{z}$ lewej strony, w czarnej sutannie, ze zlotym lańcuchem i ozdobnym dystynktorium na piersiach. Bez ram. XIX w.

138

Sw. Konrad z Parzham, kapucyn, $70 \times 133 \mathrm{~cm}$, płótno, olej. W profilu prawym, z siwą brodą, żółtą aureolą, w obu rękach trzyma krzyż, który kontempluje. Przed nim, na pulpicie leży zanknięta książka. Bez ram. Sygn.: „Pinx[it] W. Lisowski. Sanok 1936".

139

Sw. Apolinary z Posat, kapucyn, $70 \times 133 \mathrm{~cm}$, płótno, olej. W pozycji klęczącej, en face, przy stoliku, na którym leży brewiarz, i kałamarz z gęsim piórem; w lewej ręce trzyma duży krucyfiks, w prawej, złożonej na sercu ma palmę męczeńską. Bez ram. Sygn.: „WL” [W. Lisowski], 1936 r.

\section{0}

N. Maria P. Niepokalanie Poczęta, $73,5 \times 119 \mathrm{~cm}$, druk tzw. „teza” naklejona na płótno. W pozycji frontalnej, twarz trzy czwarte $w$ lewo, głowa uniesiona nieco $\mathrm{w}$ górę, $\mathrm{w}$ lewej ręce trzyma berło $\mathrm{w}$ kształcie lilii, prawa wzniesiona w prawo. Szata rozwiewna. Stoi na kuli ziemskiej, depcąc węża, pożerającego jabłko. W górze Trójca Św. koronuje Marię. U dołu, z prawej i lewej, grupa aniołów. Całość w pięknym rokokowym obramieniu. W górze napis: „Ter beata beati sponsi sponsa virginea". Sygn. z prawej u dołu: „Cum Privil[egio] Sacr[ae] Caes[arae] Majlestatis]”. „Gottlieb Heuss sculp[sit] et excud[i1] Aug[ustae] Vindlelicorum]". Z lewej u dołu: „Joann Lorenz delin[eavit]". Podniszczony. Koniec XVIII w. Rokoko.

Uwaga - jak pod nr 94.

Bibliografia: AKK, rkps 40: Inwentarz z r. 1875 s. 382. - Por. nr 96.

\section{1}

Portret mężczyzny z czarną brodą, $47 \times 66,5 \mathrm{~cm}$, płótno, olej. W owalu, w białej koszuli z czarną muszką, w brązowej marynarce. Bez ram. II poł. XIX w.

\section{2}

Ŝ. Rodzina, $119 \times 165 \mathrm{~cm}$, płótno, olej. Z lewej Matka Boska w ciemnoczerwonej szacie, prawa ręka uniesiona $w$ góre, lewa natomiast przytula do siebie Dzieciątko Jezus, owinięte w takąż szatę. Z prawej św. Józef, w niebieskiej szacie i ciemnoczerwonym płaszczu. Poniżej, z lewej putto. Tło ciemnobrązowe. I poł. XVIII w. Późnobarokowy.

\section{3}

Bł. Innocenty $\mathrm{z}$ Berzo, kapucyn, $50 \times 90 \mathrm{~cm}$, płótno, olej. W jasnożółtej aureoli, z rudą brodą i takimi włosami, w brązowym habicie kapucyńskim, z białym paskiem i różańcem. Ręce złożone na piersiach. Bez ramy. Sygn.: „T[ytus] G[orczyca] 1962”. Kopia.

\section{4}

Portret o. Beniamina Szymańskiego, kapucyna (†1868), $32,5 \times 44 \mathrm{~cm}$, litografia. W pozycji siedzącej, trzy czwarte $w$ prawo, $z$ czarną brodą, $\mathrm{w}$ piusce na głowie, w komży i pelerynie. $\mathrm{W}$ lewej ręce trzyma biret, na pier- 
siach łańcuch z pektorałem. Poniżej napis: „Beniamin Piotr Paweł I Szymańskı | Zakonu Braci Mniejszych S. Franciszka Kapucynów | Biskup diecezji Podlaskiej | Kommisarz Jeneralski Kapucynów”. Autograf: „X Benjamin Biskup”. Sygn.: „Hlenryk] Aschenbrenner. W Lit. A. Pecq et $\mathrm{C}^{\circ}$ w Warsz[awie] 482". II poł. XIX w.

Bibli og r afia: Lex. cap. szp. 1664.

145

Portret nieznanego kapucyna, $33,5 \times 42 \mathrm{~cm}$, płótno nałożone na deskę, olej. Popıersie z duzą, siwą broda, niebieskimi oczami, w brazowym habicie kapucyńskim. Bez ram. XVIII w. Późnobarokowy.

\section{6}

Sw. Serafin z Monte Granario, kapucyn (beat. 1729, kan. 1767), $109,5 \times 174 \mathrm{~cm}$, płótno, olej. W pozycji stojącej, trzy czwarte w prawo, z rudosiwą brodą i takimi włosami, w brązowym habicie z bialym paskiem, ręce wzniesione $\mathrm{w}$ górę. $\mathrm{Z}$ lewej putto $\mathrm{z}$ rózańcem $\mathrm{w}$ obu rękach, za nim drugi z rękami złozonymi do modlitwy. Postać świętego usytuowana na chmurach i w obłokach. Poniżej napis: „S[anctus] Seraphinus a Monte Gran[ario] Capucinus". II poł. XVIII w.

\section{7}

Madonna z Dzieciątkiem, $79 \times 107,5 \mathrm{~cm}$, płótno, olej. W pozycji frontalnej, en face, w czerwonej sukni i niebieskim płaszczu.

\section{8}

Sw. Antoni Padewski $z$ Dzieciątkiem Jezus, 53,5 $\times 70 \mathrm{~cm}$, płótno, olej. W ciemnobrązowym habicie, zwrócony $\mathrm{w}$ lewo, głowa przechylona trzy czwarte w prawo, oczy przymknięte, w prawej ręce trzyma swój atrybut ikonograficzny — biała lilię, a w obu rekach, opierając sie o stolik, podtrzymuje Dzieciątko Jezus, które prawą rączlkę wznosi do błogosławienia, a w lewej trzyma mały krzyżyk. Tło ciemnobrązowe. Bez ram. Pocz. XVIII w. Późnobarokowy.

\section{9}

Sw. Franciszek z Asyżu, $56 \times 66 \mathrm{~cm}$, płótno, olej. W habicie franciszkańskim, trzy czwarte $w$ prawo, głowa nieco odrzucona w tył, z lekko zaznaczoną aureolą, w lewej ręce założonej na prawą trzyma różaniec. Przed nim otwarty modlitewnik, oparty o wysoki krzyż. Święty zatopiony w kontemplacji. Tło ciemne. U dołu farba z gruntem odpadła. I poł. XVIII w. Późnobarokowy.

\section{0}

Trójca Sw., $66 \times 86,5 \mathrm{~cm}$, płótno, olej. Z prawej strony Bóg Ojciec, w niebieskiej szacie, z siwymi włosami i broda, w lewej ręce opartej o dużą zieloną kulę, wyobrazającą ziemię, trzyma duże berło, prawa ręka złożona na sercu. Z prawej Jezus Chrystus, w czerwonej szacie, z drzewem krzyża w lewej ręce. Ponad nimi, w chmurach, Duch $\$$ w. w postaci golębicy $\mathrm{w}$ aureoli promieni. U dołu farba $\mathrm{z}$ gruntem odpadła. Bez ram. XVIII w. Barokowy.

\section{1}

Matka Boska-Bolesna, $41 \times 52,5 \mathrm{~cm}$, płótno, olej. Popiersie, zwrócone lekko $\mathrm{w}$ lewo, niebieskie oczy wzniesione $\mathrm{w}$ górę, $\mathrm{w}$ niebieskim płaszczu, 
w żółtobrązowej chustce, ręce złożone na krzyż na cierniowej koronie. Sygn.: ,1889 r. Kraków".

\section{2}

Ŝw. Bonawentura, doktor seraficki, $35 \times 48 \mathrm{~cm}$, rysunek węglem. Kopia fresku Fra Angelico. W pozycji frontalnej, twarz trzy czwarte w prawo, z długą siwą brodą, wokoło głowy aureola. W obu rękach trzyma otwartą kssięgę. U dolu podpis: „Stanctus] Bonawentura Doctor Seraphicus”. Rysowal o. mgr Paweł Kochański, kapucyn, $1950 \mathrm{r}$.

\section{3}

Sw. Cecylia, patronka muzyki kościelnej, $68 \times 99 \mathrm{~cm}$, pastel. W profilu lewym, z aureolą, we włosy blond wplecione róże. W żóltej sukni i niebieskim płaszczu. Gra na organach, które znajdują się $z$ lewej strony obrazu. Malował o. Paweł Kochański, kapucyn, w r. 1948.

\section{4}

Jan Duns Szkot, $67 \times 83 \mathrm{~cm}$, płótno, olej. W pozycji frontalnej, twarz trzy czwarte w lewo, z małą bródką, w prawej ręce gęsie pióro, lewą podtrzymuje kartę otwartej księgi, lezącej na drugiej księdze. Na piersiach złoty łańcuch z pektorałem. Z prawej strony, poniżej, może biret z gęsim piórem, dalej z prawej obca ręka z mieczem. Z lewej strony głowy filozofa, Matka Boża w aureoli $\mathrm{z}$ dwunastu gwiazd, w niebieskiej sukni. Tło ściemnione. Poniżej podpis: „Joannes Duns Scotus Doctor Subtilis † 1308". I poł. XVIII w. Późnobarokowy.

\section{5}

Swięci błogosławieni i słudzy Boży z zakonu OO. Kapucynów, składają hołd Matce Bożej, $45 \times 68 \mathrm{~cm}$, miedzioryt. Madonna w górze, na chmurach $z$ prawej strony, $z$ aureola $z$ gwiazd dwunastu, en face, $z$ glowa uniesiona nieco w górę, z rękami złożonymi na sercu, w otoczeniu aniołów. Przed nią, z. lewej strony, św. Franciszek w pozycji stojącej, z głową zwrócona w lewo, obu rękami wskazuje braciom N. Marię P. Liczny zastęp świętych, błogosławionych i sług Bozych z zakonu OO. Kapucynów otacza świętego. U dołu napis: „Celsitudini Regiae Em | inentissimae Henrici S.R.E. Cardinalis | Episcopi Tusculani Ducis Eboracensis Nuncupati. I Quod universum Ordinem Min[orum] Capuccinorum in Suam Clientelam peramanter adsciverit, | tabulam hanc genuinas aere exprimentem imagines Sanctorum, Beatorum et 1 nonnullorum ex Capuccina Familia Ven[erabiliorum] Servorum Dei quos ut aureola donentur aeque Lance perpendit S[acra] Rituum Congregatio, I in exultantis gratique animi monumentum praefatus Ordo D.D.D. [Dono dedit, dedicavit]". W środku napisu znajduje się herb kardynała. Sygn.: z lewej strony“ „Franciscus Manno invenit, et pinxit”; z prawej strony“ „Alexander Mochetti sculpsit Romae 1793".

\section{6}

Św. Cyryl i Metody, apostołowie Słowian, $82 \times 112 \mathrm{~cm}$, płótno, olej. W pozycji frontalnej, stojacej, w liturgicznych szatach arcybiskupich, w mitrach na glowach, z paliuszami i pastorałami w lewych rękach. Św. Cyryl, pierwszy z lewej, trzyma mszał w prawej ręce, a św. Metody wznosi prawa rękę do błogosławienia. $Z$ obu stron otacza ich duża grupa ludzi. Ponad nimi, w chmurach, Matka Boska z Dzieciątkiem, które w lewej rączce trzyma 
palmę męczeńska. Dwaj aniołowie z góry, unoszą koronę nad głową Madonny. Przed świętymi na ziemi leży duży miecz. Tło niebieskoszare. Bez ram. Sygn.: „O. Kowalewski 1914”.

\section{7}

Portret o. Alojzego Wojnara, prowincjała, $61 \times 89 \mathrm{~cm}$, płótno, olej. Popiersie trzy czwarte $\mathrm{w}$ prawo, $\mathrm{z}$ czarną piękną brodą $\mathrm{i}$ takimi włosami, w okularach, w brązowym habicie i płaszczu kapucyńskim. Tło zielone. Sygn.: „Wiktor Skibiński fecit”, 1950 r.

158

Portret o. Leona Dolińskiego, kapucyna, $82 \times 112 \mathrm{~cm}$, rysunek czarną kredką. W owalu popiersie, zwrócone lekko $\mathrm{w}$ prawo, $\mathrm{z}$ siwą brodą, $\mathrm{w}$ habicie i płaszczu kapucyńskim. Tło białe. Sygn.: z prawej: „M. Dawidowicz. 1889”. $\mathrm{Na}$ odwrocie oryginalna klepsydra o wym. $14 \times 10 \mathrm{~cm} ., \dagger \mid \mathrm{O}$. Leon DOLIŃSKI | Definitor | Gwardyan OO. Kapucynów w Krakowie | przeżywszy lat 57, w zakonie 38, kapłaństwa 33, po długiej a ciężkiej chorobie, opatrzony S.S. Sakramentani, I zmarł w nocy z dnia 12 na 13 lipca 1890 r. | Wieczne odpoczywanie, racz Mu dać Panie, | a światłość wiekuista niechaj / Mu świeci na wiekj. ! wieków. Amen".

159

S̃w. Józef z Dzieciątkiem Jezus, $49 \times 68 \mathrm{~cm}$, płótno, olej. W pozycji frontalnej, en face, z rudą brodą i takimi włosami, w niebieskiej szacie i brązowym płaszczu, w prawej ręce trzyma Dzieciątko Jezus z rozłożonymi rękami i w białej sukience. Aureole żółte. W lewej ręce biała lilia. Tło niebieskawe. Bez ram. XIX w.

160

Portret o. Bronisława Stepka, kapucyna ( $\dagger 1925), 64,5 \times 82,5 \mathrm{~cm}$, płótno, olej. Popiersie en face, z rudą brodą, niebieskimi oczyma, z rękami opuszczonymi, w brązowym habicie kapucyńskim. Na odwrocie napis: „O. Bronisław Stepek z Haczowa Gwardyan i I Definitor od r. 1891 do 1897. Odnowiciel kościoła w Kutkorzu, od r. 1904-1910 pierwszy Gwardian konwlentu] we Lwowie". Wykonany ok. $1910 \mathrm{r}$.

\section{1}

Siw. Teresa od Dzieciątka Jezus, $126 \times 185 \mathrm{~cm}$, płótno, olej. W pozycji frontalnej, stojącej, w brązowym habicie karmelitańskim i płaszczu ultramarynowym, w niebieskim kornecie. Ręce złożone na krzyż na sercu z krucyfiksem. Od rąk do nóg zasypana różami, które również lezą u jej stóp. Tło jakby fioletowych fal morskich, w dalszej perspektywie widoczne zarysy miasta. Sygn.: „Księżna Maria Giedroyciowa”. I poł. XX w. Dnia 15 lipca 1945 r. o. Gabriel Banaś przywiózł obraz ten z Ostroga n. Horyniem $w$ ramach repatriacji.

Bibliografia: APK, rkps - Br. E. Chmiel: Kronika s. 120.

\section{2}

Portret o. Aleksandra Chmury, kapucyna ( $\dagger$ 1939), 60,5 X90 cm, plótno, olej. Popiersie z czarnosiwą brodą, twarz trzy czwarte w prawo, w habicie kapucyńskim. Tło szaropopielate. U dołu podpis: „P[ater] Alexander Chmura a Wólka Tanewska 1924-1930, 1931-1933”. Sygn.: „F. Leiter. 1933 Kraków”. 


\section{3}

Portret o. Kosmy Lenczowskiego, kapucyna ( $\dagger 1959), 42 \times 56 \mathrm{~cm}$, pastel. Popiersie en face, z brodą siwawą, oczy niebieskie, w habicie kapucyńskim. Tło jasnopopielate. Sygn.: „Dominik Ratuszny, maj 1953 r.”

\section{4}

Portret o. Ludwika Żołnierczyka, kapucyna ( $\dagger 1960), 40 \times 53,5 \mathrm{~cm}$, płyta pilśniowa, olej. Popiersie en face, z czarnymi włosami i czarnoruda brodą, oczy piwne, w habicie kapucyńskim. Tło szaropopielate. Na odwrocie napis: „O. Ludwik Żołnierczyk * 1896 † 1960”. Sygn.: na odwrocie: „O. Tytus [Gorczycal 1963".

\section{5}

Portret o. Anioła Madejewskiego, kapucyna ( $\dagger$ 1951), $25 \times 35 \mathrm{~cm}$, rysunek sangwiną. Popiersie en face, z siworuda brodą, $\mathrm{w}$ okularach, $\mathrm{w}$ piusce na glowie $\mathrm{i}$ w habicie kapucyńskim. Tło białe. Sygn.: „Stanisł[aw] Ko[...] 22. I". Około r. 1938.

\section{6}

Portret o. Honorata Jedlińskiego, kapucyna († 1952), $41 \times 48 \mathrm{~cm}$, pastel. Popiersie, twarz trzy czwarte $w$ lewo, z siwą brodą i takimi włosami, oczy niebieskie, brązowa piuska na głowie, w habicie i płaszczu kapucyńskim. Tło szarozielone i brązowe. Na odwrocie podpis: „O. Honorat Jedliński ur. 3. XI. $1869 \dagger$ 1. IX. 1952”. Sygn.: „W. Serafin. 1944”.

\section{7}

Św. Fidelis z Sigmaringen, kapucyn, $102 \times 150 \mathrm{~cm}$, płótno, olej. W pozycji trzy czwarte $w$ prawo, aureola zaznaczona świetlnym blaskiem, oczy piwne, rudosiwa broda, w prawej ręce palma męczeńska, lewa złożona na sercu. $\mathrm{Z}$ lewej strony, barokowe putto $\mathrm{z}$ biała lilią $\mathrm{w}$ prawej ręce, $\mathrm{z}$ włócznią i maczuga $w$ lewej. Putto $z$ prawej strony trzyma miecz w prawej ręce a $w$ lewej maczugę. I pol. XVIII w. Barok.

\section{8}

Bł. Apolinary z Posat, kapucyn (beat. 1926), $99 \times 148 \mathrm{~cm}$, płótno, olej. W pozycji siedzącej, lekko obrócony w prawo, broda rudosiwawa, oczy piwne, aureola jasnobrązowa, w habicie i płaszczu kapucyńskim. Prawą ręką zapisuje tekst w skrypcie gęsim piórem, w lewej trzyma otwartą księgę. Na stoliku kałamarz z gęsim piórem i krucyfiks. Z prawej strony biblioteczka. Tło brązowe. Kopia z ryciny współczesnej. I poł. XX w.

\section{9}

Św. Wawrzyniec z Brindisi, doktor Kościoła, kapucyn, $196 \times 253 \mathrm{~cm}$, płótno, olej. Opis por. Sędziszów nr 35. I poł. XX w. Płótno to przywiózł w r. 1945 z kościoła OO. Kapucynów w Olesku o. Zygmunt Nestorowski.

\section{0}

Polowanie $\mathrm{w}$ lesie, $99 \times 59,5 \mathrm{~cm}$, akwarela na papierze akwarelowym, przyklejonym na tekturze. Na białokremowym śniegu, na tle pobliskiego zielonego, sosnowego lasu, w środku sceny płonie ognisko. Wokoło grupa myśliwych ze strzelbami, w futrach i takich samych czapach. Na dalszym planie naganiacze. Tło białoszare. $\mathrm{Na}$ odwrocie napis: „Magazyn przyborów 
malarskich R. Aleksandrowicz. Kraków - ul. Basztowa 12. 450 zł." Sygn.: „S. Głowiński (?)”. I poł. XX w.

\section{1}

Portret o. Kosmy Lenczowskiego, kapucyna, $69 \times 90 \mathrm{~cm}$, płótno, olej. W pozycji frontalnej, z rudosiwą broda, oczy niebieskie, w brazowym habicie, lewa ręka załozona za biały pasek. Tło szarozielone. Sygn.: „Pinxit Karol Rutkowski A. D. 1950".

\section{2}

Portret o. Wiktora Klimka, prowincjała (†1911), 59,5 $\times 90 \mathrm{~cm}$, płótno, olej. Twarz trzy czwarte w lewo, włosy i broda rudosiwe, w okularach, w brązowym habicie. Tło szarozielonawe. U dołu podpis: „P[ater] Wiktor Klimek. Ab Ostrów 1876-1879". Malował Michał Hołyński. Lublin 1932-1933.

\section{3}

Portret o. Stanisława Krzysika, prowincjała ( $\dagger 1884$ ), $60 \times 89,5 \mathrm{~cm}$, płótno, olej. Twarz lekko zwrócona w lewo, włosy i broda rude, mała broda, oczy piwne, lewa ręka załozona za pasek. U dołu podpis: „Plater] Stanislaus Krzysik a Jasienica. 1879-1883". Malował Michał Hołyński, 1932-1933.

\section{4}

Portret o. Floriana Janochy, prowincjała (†1921), $60 \times 89 \mathrm{~cm}$, płótno, olej. W pozycji bocznej w prawo, twarz trzy czwarte $w$ lewo, oczy piwne, broda długa czarnoruda i siwawa, piuska na głowie, w prawej ręce brewiarz, w brązowym płaszczu kapucyńskim. Tło ciemno- i jasnozielone. U dołu podpis: „P[ater] Florianus Janocha ab Haczów. 1891-1897, 1900 1903'. Malował Michał Hołyński, 1932-1933.

\section{5}

Portret o. Ignacego Kolbusza, prowincjała (†1916), $60 \times 89 \mathrm{~cm}$, płótno, olej. Popiersie en face, włosy i broda rudosiwawe, oczy niebieskie, ręce opuszczone. U dołu: podpis: „Plater] Ignatius Kolbusz a Zagorzyce. 18971900. 1903-1906". Malował Michał Hołyński, 1932-1933.

\section{6}

Portret o. Augustyna Watrasa, prowincjała (†1921), $61 \times 89 \mathrm{~cm}$, płótno, olej. Popiersie en face, dluga siwa broda, czarna piuska na głowie, oczy piwne, w habicie i płaszczu kapucyńskim. U dołu napis: „Plater] Augustinus Watras a Trzeboś. 1906-1912". Malował Michał Hołyński, 1932-1933.

\section{7}

Portret o. Konstantego Jaronia, komisarza prowincjalnego († 1952), $59 \times 89,5 \mathrm{~cm}$, płótno, olej. Głowa trzy czwarte w lewo, oczy niebieskie, czarna piuska na głowie, wlosy i broda czarnorude i siwawe. U dołl napis: „Plater] Constantinus Jaroń a Głogów. 1912-1921”. Malował Michał Hołyński, 1932-1933.

\section{8}

Portret o. Czesława Szubera, komisarza prowincjalnego († 1951), $60 \times 90 \mathrm{~cm}$, płótno, olej. W pozycji bocznej w lewo, głowa en face, włosy blond, czarnoruda broda, okulary, w habicie kapucyńskim. Tło popielatobrazowe. U dołu napis: „Plater] Ceslaus Szuber ab Haczów. 1921-1927, 1930-1936". Sygn.: „F. Leiter. 1933 Kraków”. 


\section{9}

Portret o. Mariana Najdeckiego, komisarza prowincjalnego († 1951), $60,5 \times 89 \mathrm{~cm}$, płótno, olej. W pozycji siedzącej, przy brązowym stoliku, en face, czarnosiwe włosy 1 broda, piwne oczy, w habicie kapucyńskim, prawa ręka dotyka brewlarza lezącego na stoliku. Ponizej napis: „Plater] Marianus Nadecki a Jasionów. 1927-1930". Tło niebieskozielonawe. Malował Michał Hołyńskı, 1932-1933.

\section{0}

Portret o. Gerarda Rysza, komisarza prowincjalnego, $59 \times 89,5 \mathrm{~cm}$, płótno, olej. Głowa lekko zwrócona w lewo, broda i włosy czarne, oczy piwne, okulary, w habicie kapucyńskim, ręce opuszczone. U dołu podpis: „Plater] Gerardus Rysz ab Haczów. 1936-1939". Tło popielatobrązowe i czarne. Sygn.: „Titus [Gorczyca] 1937".

\section{1}

Portret o. Kazimierza Niczyńskiego, prowincjała, $60 \times 90 \mathrm{~cm}$, płótno, olej. W pozycji trzy czwarte w lewo, głowa lekko w lewo, broda siwa, widoczna duża łysina, oczy niebieskie, w rękach przed soba trzyma otwarty brewiarz. U dołu napis: „Plater] Casimirus Niczyńslki a Cracovia. 1939-1947”. Sygn.: „A. Hyła 1945”.

\section{2}

Portret o. Alojzego Wojnara, prowincjała, $60 \times 89 \mathrm{~cm}$, płótno, olej. Pólpostać w pozycji siedzącej, en face, głowa lekko przechylona w prawo, czarne włosy i czarna broda ze słabymi, siwymi smugami, oczy piwne, okulary, ręce $\mathrm{z}$ brewiarzem złożcne na kolanach. U dołu napis: „P[ater] Aloysius Wojnar a Kombornia. 1947-1950'. Malował H. Hyła. Kraków 1957.

\section{3}

Portret o. Remigiusza Kranca, prowinc jała, $60 \times 89 \mathrm{~cm}$, płótno, olej. W pozycji siedzącej, głowa lekko przechylona w prawo, włosy i broda rude, broda podgolona, oczy piwne, okulary, lewa ręka $z$ brewiarzem na kolanach. U dołu napis: „P[ater] Remigius Kranc a Krosno. 1950-1956”. Sygn.: „A. Hyła. 1957".

\section{4}

Portret o. Ernesta Łanuchy, prowincjała, $60 \times 89 \mathrm{~cm}$, płótno, olej. W pozycji siedzące j, lekko zwrócony w prawo, z czarnosiwawą brodą i włosami, oczy piwne, prawa ręka oparta o porecz czerwonego fotela, lewa złozona na kolanach. U dolu napis: „P[ater] Ernestus Eanucha a Plains Pa. 19561959”. Sygn.: „A. Hyła 1958”.

\section{5}

Św. Wawrzyniec z Brindisi, kapucyn, $8 \times 12 \mathrm{~cm}$, miedzioryt. Popiersie, trzy czwarte w prawo, długa, siwa broda, oczy spuszczone, wokoło głowy aureola, na piersiach krzyż. U dołu podpis: ,S[anctus] Laurentius a Brundusio Capuccinus". XIX w. Sztychy od nr 185 do nr 223 zostały opublikowane w I poł. XX w. z płytek XIX-wiecznych.

\section{6}

Św. Fidelis z Sigmaringen, kapucyn, $8 \times 12 \mathrm{~cm}$, miedzioryt. Popiersie, twarz trzy czwarte w lewo, włosy i broda czarnosiwe, aureola. Ponizej 
napis: „S[anctus]. Fidelis a Sigmaringen Protom[artyr] Proplagandae] Fidei". XIX w.

Bibliografia: Lex. cap. 585-587.

\section{7}

Sw. Feliks z Cantalice, kapucyn, $8 \times 12 \mathrm{~cm}$, miedzioryt. Popiersie, twarz trzy czwarte w lewo, włosy i broda siwe, oczy przymknięte, aureola. Poniżej napis: „S[anctus] Felix a Cantalicio C[onfessor]”. XIX w.

Bibliografia: Lex. cap. $574-575$.

\section{8}

Sw. Franciszek z Camporosso, kapucyn, $8 \times 12 \mathrm{~cm}$, miedzioryt. Popiersie, lekko zwrócone w lewo, włosy i broda siwe, w habicie i płaszczu kapucyńskim. Poniżej podpis: „V[enerabilis] Fr[ater] Franciscus a Camporubeo C[onfessor]". Sygn. u dołu z prawej strony: „Plio] Proja inc[idit]”. XIX w.

Bibliografia: Lex. cap. 620-621.

\section{9}

Św. Józef z Leonessy, kapucyn, $8 \times 12 \mathrm{~cm}$, miedzioryt. Popiersie zwrócone_lekko w prawo, głowa przechylona lekko w lewo, z tonsurą i brodą, z aureolą, oczy spuszczone. Ponizej podpis: „S[anctus] Joseph a Leonissa C[onfessor]". XIX w.

Bibliografia: Lex. cap. 865-867.

\section{0}

Ŝw. Serafin z Montegranaro, kapucyn, $8 \times 12 \mathrm{~cm}$, miedzioryt. Popiersie, zwrócone w lewo, głowa trzy czwarte w lewo, $z$ dużą łysiną i siwą brodą, $z$ aureolą. Poniżej podpis: „S[anctus] Seraphinus a Montegranario CLonfessor]". XIX w.

Bibliografia: Lex. cap. szp. 1583-1584.

\section{1}

Bł. Bernard z Corleone, kapucyn, $8 \times 12 \mathrm{~cm}$, miedzioryt. Popiersie zwrócone $\mathrm{w}$ lewo, $\mathrm{z}$ jasną aureola, $\mathrm{z}$ czarnymi włosami i brodą. Poniżej napis: "B[eatus] Bernardus a Corleone C[onfessor]". XIX w.

Bibliografia: Lex. cap. szp. 209-210.

\section{2}

Bł. Bernard z Ofidy, kapucyn, $8 \times 12 \mathrm{~cm}$, miedzioryt. Popiersie irzy czwarte w prawo, w jasnej aureoli, z siwymi włosami i brodą. Poniżej podpis: „Bleatus] Bernardus ab Offida Clonfessor]”. XIX w.

Bibliografia: Lex. cap. szp. 212.

\section{3}

B1. Agataniol z Vendôme i Kasjan z Nantes, kapucyni, $8 \times 12 \mathrm{~cm}$, staloryt. $\mathrm{Na}$ tle pustyni, z małymi wzniesieniami i palmami, w centrum dwaj kapucyni, w pozycji frontalnej, stojącej. Przed nimi Abisyńczyk w białej opończy krępuje ich ręce powrozem. Z lewej pozostali dwaj Abisyńczycy z wielbłądami. Obraz w ramce okolony winietką. Poniżej podpis: „BB[eati] Agatangelo da Vendôme, e Cassiano da Nantes Martiri Cappuccini”. Sygn.: „Pio Proja inc[idit]". XIX w.

Bibliografia: Lex. cap. szp. $20-21,361$. 


\section{4}

Bł. Kryspin z Viterbo, kapucyn, $8 \times 12 \mathrm{~cm}$, miedzioryt. Popiersie zwrócone $w$ lewo, $z$ jasną aureolą, z siwymi włosami i broda. Poniżej podpis: „B[eatus] Crispinus a Viterbo C[onfessor]". XIX w.

Bibliografia: Lex. cap. szp. 476.

\section{5}

Bł. Feliks z Nikozji, kapucyn, $8 \times 12 \mathrm{~cm}$, miedzioryt. Popiersie trzy czwarte $\mathrm{w}$ prawo, $\mathrm{z}$ jasną aureolą, włosy kręcone, mała broda. Ponizej podpis: „Beato Felice da Nicosia Caplpuccino]”. XIX w.

Bibliografia: Lex. cap. szp. 578.

\section{6}

B1. Aniol z Akry, kapucyn, $8 \times 12 \mathrm{~cm}$, miedzioryt. Popiersie zwrócone $\mathrm{w}$ prawo, z jasną aureola, włosy i broda siwe. Poniżej podpis: „B[eatus] Angelus ab Acrio. Clonfessor]". XIX w.

B ibliografia: Lex. cap. szp. 71-72.

\section{7}

Bł. Dydak z Cádiz, kapucyn, $8 \times 12 \mathrm{~cm}$, miedzioryt. Popiersie zwrócone $\mathrm{w}$ prawo, $\mathrm{z}$ jasną aureolą, $\mathrm{z}$ tonsurą, $\mathrm{z}$ długą siwą brodą. Błogosławiony pochylony nad krucyfiksem, który trzyma w obu rękach. Z lewej strony, u góry w promieniach, Oko Opatrzności, z którego wypływają promienie w stronę świętego. Poniżej podpis: „B[eatus] Didacus Joseph a Gadibus". Sygn.: „L. Penna inclidit]”. XIX w.

B i bliografia: Lex. cap. szp. 500-502.

\section{8}

Bl. Benedykt Passionei, kapucyn, $8 \times 12 \mathrm{~cm}$, miedzioryt. Popiersie trzy czwarte w lewo, głowa uniesiona lekko w góre, tonsura, włosy i broda siwe, z jasną aureolą. Poniżej podpis: „B[eatus] P[ater] Benedictus Passionei Lab Urbino] Clonfessor]". XIX w.

Bibliografia: Lex. cap. szp. 195-196.

\section{9}

Bł. Maria Magdalena Martinengo, kapucynka, $8 \times 12 \mathrm{~cm}$, miedzioryt. Popiersie en face, głowa lekko schylona w lewo, z jasną aureolą, oczy przymknięte, w kornecie i płaszczu zakonnym. Poniżej podpis: „Beata Maria Magdalena Martinengo C[apuccina]". XIX w.

B 1.b li o g r af i a: Lex. cap. szp. 1051-1052.

\section{0}

Sw. Weronika Giuliani, kapucynka, $8 \times 12 \mathrm{~cm}$, miedzioryt. Popiersie w pozycji frontalnej, głowa lekko zwrócona $w$ prawo, $z$ aureola, w habicie i płaszczu kapucyńskim. Poniżej podpis: „Sancltal Veronica de Julianis Clapuccina]". XIX w.

Bibliog r afia: Lex. cap. szp. 1801-1803. - Collect. francis. A. 1961 fasc. 3 w całości poświęcony jest sw. Weronice. 


\section{1}

Br. Jeremiasz z Wołoszczyzny, kapucyn, $8 \times 12 \mathrm{~cm}$, miedzioryt. Popiersie trzy czwarte $w$ lewo, $z$ brodą, oczy wzniesione $w$ górę. Poniżej podpis: „V[enerabilis] F[rater] Hieremias a Vallachia C[onfessor]”. XIX w.

B 1bliografia: Lex. cap. szp. 795.

\section{2}

Br. Rajner z Borgo San Sepolcro, kapucyn, $8 \times 12 \mathrm{~cm}$, miedzioryt. Popiersie trzy czwarte $w$ lewo, $z$ siwymi wlosami i broda, w prawej ręce na sercu trzyma malutkie Dzieciątko Jezus. Ponizej podpis: „Vlenerabilis] Flrater] Reynerius a Burgo S. Sepulchri Clapuccinus]”. XIX w.

Bibliografia: Lex. cap. szp. 1448.

\section{3}

Siostra Maria Angela Astorch, kapucynka, $8 \times 12 \mathrm{~cm}$, miedzioryt. Popiersie trzy czwarte w lewo, glowa w profilu lewym, w kornecie i habicie. Ponize] podpis: „V[enerabilis] Soror Maria Angela Astorhe C[apuccinal”. XIX w.

B ibli ografia: Lex. cap. szp. 69-70.

\section{4}

Br. Jerzy z Augsburga, kapucyn, $8 \times 12 \mathrm{~cm}$, miedzioryt. Popiersie trzy czwarte $w$ lewo, głowa pochylona $w$ dól, włosy i broda siwe, oczy przymknięte. Poniżej podpis: „V[enerabilis] F[rater] Georgius ab Augusta Clapuccinus]". XIX w.

Bibliografia: Lex. cap. szp. 678.

\section{5}

O. Karol z Motrone, kapucyn, $8 \times 12 \mathrm{~cm}$, miedzioryt. Popiersie trzy czwarte w prawo, z tonsura, włosy i broda siwe. Ponizej podpis: „Vlenerabilis] P[ater] Carolus a Motrone Clapuccinus]". XIX w.

B i bli o gr afia: Lex. cap. szp. 352.

\section{6}

O. Ignacy z Santhia, kapucyn, $8 \times 12 \mathrm{~cm}$, miedzioryt. Popiersie w pozycji frontalnej, głowa lekko zwrócona w lewo i pochylona w dół, znaczna łysina, włosy i broda siwe. Poniżej podpis: „V[enerabilis] P[ater] Ignatius a S[ancta] Agatha Clapuccinus]". XIX w.

B i b li o gr a fi a: Lex. cap. szp. $802-803$.

\section{7}

O. Franciszek $\mathrm{z}$ Bergamo, kapucyn, $8 \times 12 \mathrm{~cm}$, miedzioryt. Popiersie trzy czwarte $w$ lewo, $z$ tonsura, whosy i broda siwe. Poniżej podpis: „Vlenerabilis] P[ater] Franciscus a Bergamo Clapuccinus]”. XIX w.

Bibliografia: Lex. cap. szp. 618.

208

O. Mikołaj Molinari, biskup, kapucyn, $8 \times 12 \mathrm{~cm}$, miedzioryt. Popiersie lekko zwrócone w prawo, $z$ siwą brodą, w sutannie biskupiej i piusce, na piersiach lańcuch z krzyżem. Ponizej podpis: „Ven[erabilis] Nicolaus Molinari Clapuccinus] Bovini Episcopus". XIX w. 


\section{9}

Br. Andrzej z Burgio, kapucyn, $8 \times 12 \mathrm{~cm}$, miedzioryt. Popiersie trzy czwarte w prawo, z czarnymi włosami i siwą broda, oczy spuszczone. Poniżej podpis: „V[enerabilis] F[rater] Andreas a Burgio C[apuccinus]". XIX w.

Bibli og $r$ afia: Lex. cap. szp. 66 .

\section{0}

Siostra Floryda Cevoli, kapucynka, $8 \times 12 \mathrm{~cm}$, miedzioryt. Popiersie w pozycji frontalnej, głowa lekko zwrócona w lewo i pochylona w dół, na piersiach stylizowane serce $\mathrm{z}$ kulą ziemską i krzyżykiem w środku. Poniżej podpis: „V[enerabilis] Soror Florida Ceoli Clapuccina]". XIX w.

Bibliografia: Lex. cap. szp. 595-596.

\section{1}

Br. Ignacy z Laconi, kapucyn (beat. 1940, kan. 1951), $8 \times 12 \mathrm{~cm}$, miedzioryt. Popiersie trzy czwarte w lewo, głowa lekko podniesiona $w$ górę, łysy, z siwą duzą brodą. Poniżej podpis: „V[enerabilis] Flrater] Ignatius a Laconi Clapuccinus]”. Sygn.: „G. Mochetti inc[idit]”. XIX w.

B ibli ografia: Lex. cap. szp. $800-801$.

\section{2}

O. Franciszek $\mathrm{z}$ Precetto, kapucyn, $8 \times 12 \mathrm{~cm}$, staloryt. Popiersie trzy czwarte w lewo, $\mathrm{z}$ tonsura, $\mathrm{z}$ oczyma opuszczonymi, $\mathrm{z}$ siwawymi włosami i broda. Poniżej podpis: „V[enerabilis] P[ater] Franciscus a Praecepto C[apuccinusl". XIX w.

B ibliografia: Lex. cap. szp. 633.

\section{3}

O. Dominik Antoni z Rzymu, kapucyn, $8 \times 12 \mathrm{~cm}$, staloryt. Popiersie trzy czwarte w lewo, głowa prawie całkiem zwrócona w lewo, lekko podniesiona $\mathrm{w}$ górę, $\mathrm{z}$ siwa tonsurą i brodą. Poniżej podpis: „V[enerabilis] Plater] Dominicus Antonius a Roma Clapuccinus]". Sygn.: „O. Persichini inclidit]". XIX w.

B i bli og rafia: Lex. cap. szp. 514.

\section{4}

O. Honorat z Paryża, kapucyn, $8 \times 12 \mathrm{~cm}$, miedzioryt. Popiersie trzy czwarte $\mathrm{w}$ prawo, głowa podniesiona $\mathrm{w}$ górę, łysina, duża, siwa broda. Poniżej podpis: „V[enerabilis] P[ater] Honoratus Parisiensis Clapuccinus]". XIX w.

B i b li o grafia: Lex. cap. szp. $771-772$.

\section{5}

O. Jezuald $\mathrm{z}$ Reggio Calabria, kapucyn, $8 \times 12 \mathrm{~cm}$, staloryt. Popiersie trzy czwarte $w$ lewo, tonsura, siwa broda. oczy przymknięte, prawa ręka oparta na lasce, lewa założona na zakonny płaszcz. $Z$ lewej strony, na stoliku, infuła i pastorał. Poniżej podpis: ,V[enerabilis] P[ater] Iesualdus a Rhegio Iulii C[apuccinus]”. Sygn.: „O. Parsichini inc[idit]”. XIX w.

B ibli ografia: Lex. cap. szp. $797-798$.

\section{6}

O. Franciszek z Lagonegro, kapucyn, $8 \times 12 \mathrm{~cm}$, staloryt. W pozycji stojącej, bekko obrócony w lewo, prawą ręką podaje chleb chłopcu, który wyArchiwa Kosicielne - T. 11 
chyla się z okna domu, w lewej trzyma książkę, na prawym przedramieniu założony worek kwestarski i stuła. Poniżej podpis: „V[enerabilis] P[ater] Franciscus a Laculibero Clapuccinus]". XIX w.

Bibliografia: Lex. cap. szp. 627 .

\section{7}

Bonawentura Barberini, arcybiskup, kapucyn, $8 \times 12 \mathrm{~cm}$, staloryt. Popiersie trzy czwarte $w$ lewo, włosy i broda siwe, w piusce na głowie i biskupim mucecie, na piersiach paliusz i łańcuch z krzyzem. Poniżej podpis: "Ven[erabilis] Bonaventura Barberini C[apuccinus] Archiepiscopus Ferrariensis”. Sygn.: „O. Persichini inclidit]”. XIX w.

Bibli ografia: Lex. cap. szp. 169 .

O. Wawrzyniec z Zibello, kapucyn, $8 \times 12 \mathrm{~cm}$, staloryt. Popiersie lekko zwrócone w prawo, głowa schylona w dół, duża łysina, długa siwa broda. Poniże] podpis: „V[enerabilis] P[ater] Lorenzo da Zibello C[apuccinus]". Sygn.: „O. Persichini inc[idit]”. XIX w.

Bibliografia: Lex, cap. szp. 933.

\section{9}

Siostra Maria Laurencja Longo, kapucynka, $8 \times 10,2 \mathrm{~cm}$, staloryt. Cela zakonna, $z$ prawej fragment pulpitu nakrytego obrusem, na nim ksiega i kałamarz z gęsim piórem; z lewej klęcznik z dużym krucyfiksem. Obok pulpitu, w pozycji stojącej, siostra Maria, trzy czwarte w lewo; w lewej ręce trzyma księgę z napisem: „Regula et vita sororum pauperum” a prawą wskazuje tekst klęczącym obok siostrom. Ponize] podpis: „V[enerabilis] Soror Maria Laurentia Longo Monialium Capuccinarum Fundatrix". Sygn. z lewej pod sztychem: „G. B. Gagliardii dep[inxit].; z prawej: „P. Proja inclidit]". XIX w.

Bibli o grafia: Lex. cap. szp. 1049.

220

Siostra Maria Diomira od Słowa Wcielonego, kapucynka, $8 \times 10 \mathrm{~cm}$, staloryt. W pozycji frontalnej, en face, ręce złożone na krzyż na sercu, w prawej krucyfiks, w lewej różaniec. Poniżej podpis: „V[enerabilis] Sor[or] Maria Diomira a Verbo Incarnato C[apuccina]”. Sygn.: „P. Proja incLidit]”. XIX w.

B i b li ografi a: Lex. cap. szp. 506 .

\section{1}

O. Józef z Carabantes, kapucyn, $8 \times 12 \mathrm{~cm}$, miedzioryt. Popiersie trzy czwarte w lewo, $\mathrm{z}$ tonsurą $\mathrm{i}$ siwawą broda, $\mathrm{z}$ ust wypływają promienie $z$ 'trzema gwiazdkami. Ponizej podpis: „V[enerabilis] P[ater] Joseph a Carabantes C[apuccinus]". XIX w.

Bibli o grafia: Lex. cap. szp. 859-860.

\section{2}

O. Marek z Aviano, kapucyn, $8 \times 12 \mathrm{~cm}$, miedzioryt. Popiersie trzy czwarte $\mathrm{w}$ lewo, $\mathrm{z}$ tonsura i siwawą brodą, oczy przymknięte, ręce złożone do modlitwy. Poniżej podpis: „V[enerabilis] Fr[ater] Marcus ab Aviano C[apuccinus]”. Sygn.: „Pio Proja inc[cidit]”. XIX w.

B i b li ografia: Lex. cap. szp. 1035--1038. 
Br. Józef z Palermo, kleryk kapucyński, $8 \times 12 \mathrm{~cm}$, miedzioryt. Popiersie w pozycji frontalnej, głowa trzy czwarte w lewo, bez brody, z czarną tonsurą. Ponizej podpis: „S[ervus] D[ei] Fr[ater] Josephus M[aria] a Panormo Clericus Novitius O[rdinis] M[inorum] Cap[uccinorum]". Sygn.: „Pio Proja inclidit]”. XIX w.

B ibliog rafia: Lex. cap. szp. 870.

\section{4}

Portret Seweryna Józefa Rzewuskiego, fundatora klasztoru OO. Kapucynów w Olesku, $38 \times 45,5 \mathrm{~cm}$, plótno, olej. Popiersie w owalu, lekko zwrócone w prawo, głowa trzy czwarte w lewo, znaczna łysina, małe wąsy, oczy niebieskie, w białym zupanie i karmazynowym kontuszu z wylotami zarzuconymi na plecy, kontusz obszyty z brzegów złotym obramowaniem. Na piersiach niebieska wstęga $\mathrm{z}$ orderem Orła Białego $\mathrm{i}$ gwiazdą orderową. Prawą ręka wsparty pod pachę. $\mathrm{Na}$ odwrocie ramy napis: „Portr[et] fund[atora] klasztoru oleskiego". Portret ten znajdował się do r. 1944 w refektarzu klasztornym w Olesku. Sygn. na odwrocie płótna: „I. A.G. O. S. B” - prawdopodobnie I. Antonius Gruszecki Ordinis Sancti Basilii. II poł. XVIII w.

Bibliografia: Rastawlecki (Słownik malarzów polskich, s. 190) podaje następujące inicjały artysty: L. A. G. O. S. B.; atoli na portrecie występuje bardzo wyraźnie I a nie L; Br. Ernest [E a n u ch a] kap[ucyn]: W dwusetną rocznicę oleskiego klasztoru. Wiad. Prow. Krak. Kapuc. R. 2: 1939 nr 1 s. 19.

\section{5}

Portret O. Alfonsa Wieczorka, kapucyna, $40,2 \times 58 \mathrm{~cm}$, płótno, olej. Półpostać w pozycji siedzącej, trzy czwarte w lewo, z czarnorudymi włosami i brodą, spod szkaplerza widoczny łańcuszek od zegarka $z$ dewizką, lewa ręka złożona na kolanie. Sygn.: „F. Leiter. 1928”. Poprzednio własność p. Kostkówny z ul. Garncarskiej.

\section{6}

Chrystus cierniem ukoronowany, $45,5 \times 60,5 \mathrm{~cm}$, deska lipowa, olej. Popiersie $w$ pozycji frontalnej, głowa przechylona w lewo, włosy i broda blond, oczy wzniesione $\mathrm{w}$ górę, na ramiona zarzucona niebieskawa szata, prawa ręka skrępowana złotym sznurem i przywiązana do szyi, na głowie pozłacana cierniowa korona, w ręce pozłacany kij. Szata, cierniowa korona i kij są płaskorzeźbami. Tło granatowe. Sygn. na odwrocie: „R. P. 1830”.

\section{7}

Przysięga Tadeusza Kościuszki w kaplicy Loretańskiej, $54 \times 74,5 \mathrm{~cm}$, płótno, olej. Na tle ołtarza Matki Bożej Loretańskiej, z obrazem M. B. na zasuwie i biurkiem króla Jana Sobieskiego, na podium ołtarza z prawej strony stoi o. Florian Janocha, w białej albie i czerwonym ornacie, w pozycji trzy czwarte w lewo, z piękną siwą brodą, z prawą ręką wzniesioną do błogosławienia. Przed nim z lewej Tadeusz Kościuszko we fraku, źółtawej kamizelce $\mathrm{i}$ białych spodniach $\mathrm{w}$ delikatme ciemne prążki, z niebieską szarfą na piersiach, w prawej ręce szabla opuszczona w dól, za nim poniżej, gen. Józef Wodzicki, z siwymi włosami, w niebieskim mundurze generalskim i szablą wyciągniętą przed siebie. Z prawej posługuje br. Teofil Kowalik, zakrystian i kleryk Gerard Rysz; z lewej stoi br. Rajmund Półchłopek w komży, który wykonał dekorację oltarza. Malował Eugeniusz Dołganow w r. 1921. Ze zbioru br. Rajmunda Półchłopka. 


\section{8}

Ołtarz św. Feliksa z Cantalice w kościele OO. Kapucynów w Krakowie, $48 \times 68 \mathrm{~cm}$, płótno, olej. W niszy ołtarzowej figura świętego, słynąca laskami (dziś nieistniejąca); w zwieńczeniu ołtarza chusta św. Weroniki z obliczem Chrystusa; na predelli obraz $\mathrm{nr}$ 226. Antepedium z czerwonymi tulipanami i napisem: "Swięty Feliksie módl się za nami". Dekoracja ołtarza na uroczystość odpustową w dniu 18 maja 1921 r. wykonana przez br. Rajmunda Półchłopka. Ołtarz ozdobiony białymi irysami a z boku dwie palmy kokosowe i zielone krzewy. Sygn.: „E[ugeniusz] Dołganow, 18 maja 1921 r. Kraków”. Ze zbioru br. Rajmunda Półchłopka.

\section{9}

Ołtarz Zwiastowania N. Marii P. w kościele OO. Kapucynów w Krakowie, $59 \times 84,5 \mathrm{~cm}$, płótno, olej. W ołtarzu dawne jeszcze tabernakulum, z obliczem Pana Jezusa na drzwiczkach (nr 232). Antepedium białe z Matką Boską i Dzieciątkiem. $Z$ boku oltarza po jednej wiecznej lampie. Ołtarz udekorowany artystycznie przez br. Rajmunda kampanulami, u dołu zaś paprocia, względnie zielonymi krzewami. Płótno w górnej części sztukowane. Sygn.: „E. Dołganow. 13. 12. 1921". Ze zbioru br. Rajmunda Półchłopka.

\section{0}

Ołtarz Niepokalanego Poczęcia N. Marii P. w kościele OO. Kapucynów w Krośnie, $70 \times 99 \mathrm{~cm}$, płótno, olej. Wokoło obrazu liczne wota z czerwonych korali. Dekoracja ołtarza wykonana przez br. Rajmunda Półchłopka. Sygn.: „Stlanisław] Bergman”. I poł. XX w. Ze zbiorów br. Rajmunda Półchłopka.

\section{1}

Matka Boska z Dzieciątkiem Jezus, $17,5 \times 21,5 \mathrm{~cm}$, deska, olej. W pozycji siedzącej, zwrócona w prawo, twarz trzy czwarte w prawo, w czerwonej sukni i niebieskim płaszczu, z Dzieciątkiem w obu rękach. Dzieciątko Jezus $\mathrm{w}$ białej sukience. Z prawej strony widoczna głowa, może św. Józefa. Tło ciemne. Barok. Na przylepionej kartce $z$ lewej strony u góry napis: „Obrazek który dostał przy pierwszej Komunii św. ś. p. o. Wacław Nowakowski (+ 1903)". Barok. Bez ram. I poł. XIX w.

\section{2}

Oblicze Pana Jezusa, $18,5 \times 25 \mathrm{~cm}$, blacha miedziana, olej. Karnacja białoczerwona, broda rudobrązowa, wlosy rudawe opadające obficie z obu stron głowy. Tło białe. Szkoła niemiecka. Ok. XVI w. Dar ks. kan. Józefa Olechowskiego w 1775 r. Pochodzi z kościoła św. Barbary w Krakowie.

Bibliografia: AKK, rkps HCC, I s. 169: „Imago Salvatoris apposita ad ostium in tabernaculo maioris altaris. Hanc imaginem expetiit et obtinuit $R$. P. Ludovicus guardianus ab IIl[ustris]s[i]mo R[evere]nd[is]s[i]mo D[omi]no Josepho Olechowski Canonico Cathedrali et post suffraganeo cracoviensi, quam ille habuit ex ecclesia S[an]ctae Barbarae post extinctam Societatem Jesu. Imago haec prout retulit quidam ex PP[atri]bus Jesuitis fuit a quodam abbate Marochiensi dono data Serenissimae Reginae uxori Sigismundi. Mereturque non solum maximam devotionem, sed et aestimationem summam propter antiquissimam, excellentissimam atque ab omnibus dilaudatam picturam". - AKK, rkps 38: Inwentarz z r. 1839 k. 1: „Ramka na obrazku Twarzy P. Jezusa na drewnie. W depozytorium". - AKK, rkps 39: Inwentarz z r. 1821 k. 18, 44, 63v; Inwentarz z r. 1858 k. 101. - AKK, rkps 40: Inwentarz z r. 1875 s. 18. - APK, rkps - O. P. K ochański: Kościół Zwiastowania s. 55. - O. W. Nowakowski: Pamiątka s. 18. - M. Skrudilk: O klasztorze OO. Kapucynów w Krakowie. 


\section{3}

Chrystus cierniem ukoronowany, $29 \times 36 \mathrm{~cm}$, blacha cynkowa, olej. Popiersie w owalu, zwrócone w lewo, włosy czarne, korona cierniowa ledwie widoczna, ręce złożone na piersiach na krzyż i skrępowane sznurem. Tło czarne i ciemnobrązowe. Bez ram. XVIII w.

Bibliografia: AKK, rkps 40: Inwentarz z r. 1875 s. 116.

\section{4}

Portret Mikołaja Hartunga z r. $1863,12 \times 15 \mathrm{~cm}$, płótno, olej. Miniatura w owalu, prawdopodobnie wycięta z nieco większego malowidła. Podniszczona. $\mathrm{Na}$ odwrocie napis: „Mikołaj Hartung Sybirak 1863 r.”, prawdopodobnie wykonany ręką o. Wacława Nowakowskiego.

\section{5}

Matka Boska z Dzieciątkiem, $50 \times 63 \mathrm{~cm}$, płótno, olej. Pólpostać z Dzieciątkiem na lewym ręku, głowa trzy czwarte w prawo, oczy przymknięte. Na głowie trzy róże $\mathrm{z}$ listkami $\mathrm{w}$ formie wieńca, $\mathrm{z}$ szeroką złotą aureolą $\mathrm{z}$ zielonymi pasemkami, w złotej sukni i srebrnym płaszczu; prawa ręka spoczywa na sercu. Tło niebieskie. Bez ram; bardzo zniszczony. Około 1810 r. Pochodzi z kolekcji o. W. Nowakowskiego.

\section{6}

Matka Boska Częstochowska, $47 \times 65 \mathrm{~cm}$, płótno, olej. W koronach, w czerwonej sukni i fioletowoniebieskim plaszczu, wokoło głowy 12 gwiazd. Tło złote. Bez ram. Prawdopodobnie wyciśnięta na płótnie z gotowych klisz. XIX w. Ze zbiorów o. Wacława Nowakowskiego.

\section{7}

Matka Boska Rzeszowska w kościele OO. Bernardynów, $75 \times 95 \mathrm{~cm}$, płótno, olej. Na pierwszym planie rozłożyste zielone drzewo z objawioną Matką Boską z Dzieciątkiem Jezus. Madonna w kolorach, w postawie frontalnej, stojącej, różowej sukni i zielononiebieskim płaszczu, Dzieciątko w różowej sukience. $Z$ prawej strony widoczny duży klasztor, z lewej, pod drzewem, grupa rozmodlonych ludzi. Tło jasnoniebieskie. Bez ram, bardzo zniszczony. XVIII w. Prawdopodobnie ze zbiorów o. Wacława Nowakowskiego. s. 581 .

B ibli ografia: O. W. Nowakowski: O cudownych obrazach w Polsce

\section{8}

Trójca Św.: $51 \times 63 \mathrm{~cm}$, płótno, olej. Bóg Ojciec z głową przechyloną w lewo, w pozycji stojącej, z siworudymi włosami i długiej brodzie, okrywa białym prześcieradłem Chrystusa zdjętego z krzyża. Nad nimi Duch Sww., $\mathrm{w}$ postaci gołębicy. Z prawej putto $\mathrm{z}$ gwoździami w prawej ręce, $\mathrm{z}$ lewej putto $z$ włócznią w lewej ręce. Bez ram. XVIII w. Barok. Obraz należał kiedyś do rodziny Grojeckich. Ostatnio podarowała płótno do klasztoru OO. Kapucynów w Krakowie Maria Pawlikowska, w podzięce za otrzymaną od Boga łaskę, wyproszoną za pośrednictwem Padre Pio da Pietralcina.

\section{9}

Karmelici przy piwie, $42 \times 32 \mathrm{~cm}$, płótno podlepione na dykcie, olej. Przy stole w refektarzu trzech karmelitów z kuflami piwa. Na stole chleb i rzodkiewka. Sygn. z prawej w górze: „R. Frigerio”. Na odwrocie, na etykietce napis: „Kunst-Gläserei Bilder, u. Spiegel-Einrahmung von Rudolf Pölke, 
Berlin SW., Friesenstr. 21. Grosses Langer fertiger Aquarell- und Kupfertche, Lager von Photographie-Ständern in Glas, Holz und Metall". Dar o. Tytusa Gorczycy, kapucyna.

\section{0}

Klasztor OO. Kapucynów w Sędziszowie Małopolskim, $35 \times 17 \mathrm{~cm}$, akwarela na papierze czerpanym. Widok od strony ogrodu, gmach jednopiętrowy, pokryty czerwonymi dachówkami, ściany białe. Drzewa bez liści, ogród tonie w śniegu. Tło niebieskie. Sygn. z prawej strony u dołu: „Frlater] Ephrem [Klawitter] a Kcynia O. M. Cap. pinxit 1921". Ofiarowany mistrzowi nowicjatu o. Marianowi Najdeckiemu.

\section{1}

Chrystus cierpiący, $22 \times 27,5 \mathrm{~cm}$, litografia kredowa. Popiersie trzy czwarte w lewo, w koronie cierniowej, prawą ręką wsparty o czoło, oczy spuszczone. Głowa pochylona w lewo. Z prawej napis: „Płacze nad wami ! Boleści łzami | Boście nie poszli | Za mojemi słowy, | Od cierni wasze Uchylajac głowy”. Sygn. z prawej strony u dołu: „Jan Styka. 1883”.

242

Miniatura o. Wacława Nowakowskiego, kapucyna, $12 \times 14 \mathrm{~cm}$, płótno, olej. Popiersie w owalu, trzy czwarte w prawo, włosy i broda siwe, oczy niebieskie, w brązowym habicie kapucyńskim. Sygn. u dołu: „Wojciech Eliasz [Radzikowski] 1896". Dar dr Marii Estreicherówny dla o. Kornela w r. 1963.

243

Matka Boska z Dzieciątkiem, $34 \times 45 \mathrm{~cm}$, płótno, olej. Półpostać w pozycji frontalnej, $z$ Dzieciątkiem na lewej ręce, prawa ręka złożona na sercu. Jezus w lewej raczce trzyma książeczkę, prawa wzniesiona do błogosławienia. Płótno pokryte metalową sukienką $z$ aureolą i stylizowanymi koronami, jakkolwiek sam obraz jest bez koron. Wokoło ramy ozdobna bordiurka. Ruska ikona nabyta przez o. Kornela Gadacza w czasie okupacji od żolnierza Czecha $\mathrm{z}$ armii niemieckiej. XVIII $\mathrm{w}$.

\section{4}

Miniatura Albrechta Dembińskiego, fundatora klasztoru OO. Kapucynów w Krakowie, $9,8 \times 12,5 \mathrm{~cm}$, płótno, olej. Popiersie w owalu, lekko zwrócone w prawo, włosy i wąsy czarne, oczy piwne, delia karmazynowa. Tło niebieskawe. W refektarzu zakonnym wisiał on, pod obrazem Ukrzyżowania ( $\mathrm{nr}$ 64), na czolowej ścianie, między lawą prowincjalską a gwardiańską. Przez długi okres czasu uważany był za portret króla Jana Sobieskiego. XVII w. Barok.

B i b li og rafia: AKK, rkps 38: Inwentarz z r. 1839 k. 9, na której zapisano, że portret wyobraża fundatora. - AKK, rkps 39: Inwentarz z r. $1821 \mathrm{k}$. 40, 54 . AKK, rkps 40: Inwentarz z r, 1875 s. 384, gdzie podano, że portret przedstawia fundatora.

\section{5}

Podasyski pejzaż, $30 \times 34 \mathrm{~cm}$, płótno, olej. Na pierwszym planie uroczy kościółek i dzwonnica. Dalej rozległa równina, pokryta zielenią, na tle wysokich, różowo-fioletowoniebieskich gór. Sygn.: „P[ater] Ephrem Maria a Kcynia". I poł. XX w. Dar ks. dziekana Kazimierza Sikory z Kcyni.

\section{6}

Fragment Jasnej Góry, 49,5 ×65 cm, płótno, olej. Chodnik prowadzący do klasztoru, z obu stron mur, na szczycie muru z prawej strony figura święta, 
z lewej widoczna wysoka wieża i fragment budynku. Zza muru wylaniają się zielone drzewa. Bez ram. Sygn. u dołu z prawej: „M. Bieszczanin. 1948”.

\section{7}

Fragment starego Gdańska w ruinach, $61 \times 38 \mathrm{~cm}$, płótno, olej. Na tle brązowawych ruin, z lewej strony widoczny kościółek i z prawej drugi. Wśród ruin, w centrum, wyrastają zielone drzewa. Kolorystyka brązowa. Bez ram. Sygn. u dołu z prawej: „M. Bieszczanin. Gdańsk 1948”.

\section{8}

Kaplica św. Stanisława w katedrze na Wawelu, $41 \times 56,5 \mathrm{~cm}$, autolitografia kredowa, wielobarwna. Cztery marmurowe schody prowadzą do kaplicy; z lewej strony kolumny marmurowe; w głębi, w złotym kolorze, kaplica św. Stanisława. Sygn. u dołu z prawej:,, L. Wyczółkowski”. I poł. XX w.

\section{9}

Klasztor OO. Kapucynów w Krośnie, $61,5 \times 42 \mathrm{~cm}$, akwarela. Widok od strony ogrodu. Białe ściany klasztoru i żółtawe ściany kościoła z zielonym dachem. $Z$ lewej mur ogrodowy i zielone drzewa. Tło niebieskawe. Sygn. u dołu z prawej: „Giemzawski”. I poł. XX w.

\section{0}

Portret biskupa Karola Fischera, sufragana przemyskiego, 44,3 $\times 60,5 \mathrm{~cm}$, rysunek kredką sepiową. Popiersie trzy czwarte w prawo, głowa prawie całkiem w prawo, siwe włosy, na głowie piuska, na piersiach łańcuch z krzyżem. Głowa umieszczona w brązowawym kwadracie. Sygn. z lewej u dołu: „Fr[ater] Ephrem a Kcynia O. M. Cap. fecit”. 1921 r. Do r. 1962 znajdował się on w klasztorze OO. Kapucynów w Sędziszowie.

\section{1}

Portret o. Antonina Przedwojewskiego, biskupa, kapucyna $(+1793)$, $27 \times 36 \mathrm{~cm}$, rysunek ołówkiem. Popiersie w owalu, trzy czwarte $w$ lewo, $\mathrm{z}$ siwą brodą, z łańcuchem i krzyżem na piersiach, w mucecie; prawa ręka z biretem złożona na sercu. Sygn.: „S[tanisław] Fabijański. 1886. I".

\section{2}

Matka Boska $\mathrm{z}$ Dzieciątkiem w koronach, $27 \times 31,5 \mathrm{~cm}$, blacha miedziana, olej. Glowa Madonny lekko zwrócona w prawo, Dzieciątka Jezus w lewo. Matka Boska w czerwonej sukni, przepasanej białym paskiem, w niebieskim płaszczu, z rudymi włosami rozpuszczonymi na plecy, w prawej ręce berło. Dzieciątko w blond wlosach, w białej sukience, prawa ręka wzniesiona do błogosławienia, w lewej trzyma kulę ziemską z krzyżykiem. Wokoło głów jasna aureola. XIX w.

\section{3}

Kościół zabytkowy w Haczowie, $45 \times 30 \mathrm{~cm}$, płótno, olej. Na cmentarzu kościelnym, okolonym parkanem, stoi wśród drzew średniowieczny, zabytkowy kościół drewniany $z$ wieżyczką i sygnaturką. Z lewej strony krzyż misyjny; przed kościołem kapucyn (o. Florian) odmawia brewiarz; z prawej widoczna brama prowadzaca do kościoła. Kolorystyka brązowawozielona. Sygn. $u$ dołu z prawej: „X. Floryan [Janocha]. 1903”. W APK znajduje się reprodukcja obrazu publikowana w formie pocztówli. 


\section{4}

Matka Boża Pięknej Miłości, 35,5 ×45,5 cm, blacha miedziana, olej. Madonna z Dzieciątkiem Jezus na lewej ręce, w postawie siedzącej, zwrócona lekko w prawo, twarz en face, włosy czarne, na głowie mała poduszeczka z koroną, oczy piwne, suknia czerwona, płaszcz niebieski. Prawa ręka założona na kolanach Dzieciątka. Dzieciatko w białej sukience, prawą rączkę złożyło na prawej ręce Madonny, w lewej trzyma białą różę. Wokoło głów szeroka aureola źółtego światła. Na odwrocie obrazu panegiryk $z$ okazji imienin o. Kiliana Żywieckiego, definitora prowincji polskiej OO. Paulinów i przeora klasztoru na Jasnej Górze w Częstochowie. Podarek złożyli zakonni współbracia. Inne napisy: „Sebastianus Szałdrzyński, parochus in Jelesno 1699”, „Dnia 18 September 1812 Jan Tilher”. Ok. 1660-1666. Barok.

Bibliog rafia: Archiwum Klasztoru OO. Paulinów w Częstochowie, rkps 77 k. 83-83v. O. Wacław Kilian Żywiecki, po studiach w Akademii Krakowskiej, wstąpił do Paulinów 7 lipca 1641. Po zakonczeniu wojen szwedzkich był przeorem na Jasnej Górze przez 6 lat. Spełniał też w prowincji Paulinów inne ważne funkcje. Ogólnie kochany przez podwładnych, zmarł 10 czerwca 1672.

\section{5}

Klasztor OO. Kapucynów w Krakowie, $24 \times 19 \mathrm{~cm}$, dykta, olej. Na pierwszym planie mogiła Konfederatów Barskich, z wysokim krzyżem i ogrodzeniem. Elewacja kościoła jasnoczerwona, dach szary, ściany kaplicy Loretańskiej, jak biblioteki, zóltawe z dachem ciemnoczerwonym. Na odwrocie pieczątka firmowa: „Magazyn uniwersalny. Roman Drobner. Kraków”. Prawdopodobnie malował Kwiatkowski, I poł. XX w.

\section{6}

Portret o. Alojzego Wojnara, kapucyna, prowincjała, $34,8 \times 50 \mathrm{~cm}$, płótno, olej. Półpostać trzy czwarte $w$ lewo, glowa prawie $w$ profilu lewym, uniesiona $w$ górę, długa, brązowawa broda i tonsura, oczy wpatrzone w krucyfiks z lewej strony, prawa ręka złożona na księdze. Między krucyfiksem a głową widoczna alegoria śmierci $w$ białej szacie, $z$ kapturem na głowie, grająca na skrzypcach. W górze napis: „Benedicite omnia opera Domini Domino”. Poniżej z. prawej napis: „P[ater] Aloysius Wojnar a Kombornia 1947--1950”. Sygn.: „K. Puchała 1950".

\section{7}

Sw. Maria Magdalena, $44 \times 54,5 \mathrm{~cm}$, plótno, olej. Popiersie trzy czwarte w lewo, głowa opuszczona w dół, ręce złożone na krzyż na sercu, jasnoczerwonej sukni i niebieskim płaszczu oraz takiej chustce na głowie. Aureola zaznaczona lekko delikatnym światłem. Tło brązowociemne. I poł. XX w.

\section{8}

Św. Franciszek z Asyżu, 53,2 X68,3 cm, płótno nalepione na dyktę, olej. Półpostać w pozycji stojącej, głowa lekko zwrócona w prawo, w kapturze i habicie kapucyńskim, ręce wlożone w rękawy, na prawym boku widoczny stygmat. Wokoło głowy świetlna aureola. W górze napis: „S. Franciszek Seraficzny". Tło ciemne. Jest to kopia z obrazu Sz. Czechowicza nr 12 . II poł. XVIII $\mathrm{w}$, 
259

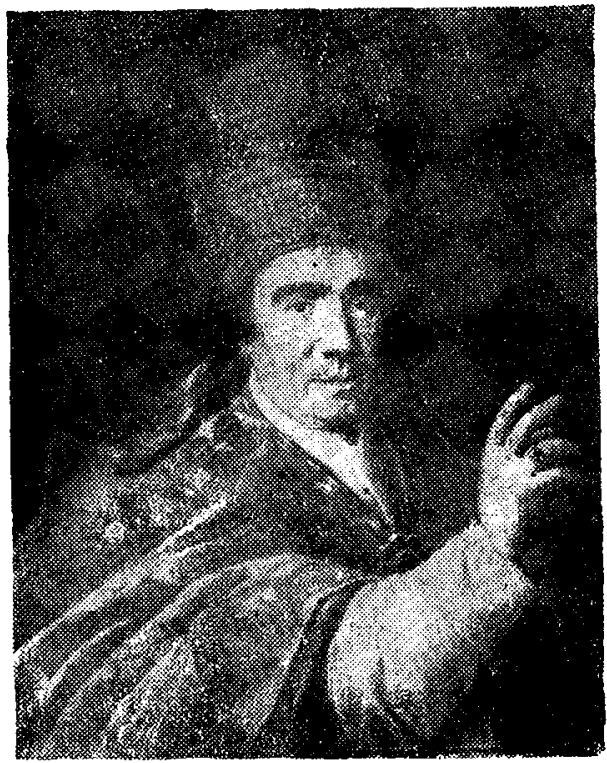

Portret papieża Klemensa XI, $61,5 \times 73 \mathrm{~cm}$, płótno, olej. Popiersie trzy czwarte w prawo, glowa lekko

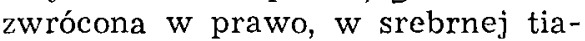
rze wysadzanej drogimi kamieniami, w białej albie i srebrnej kapie ze zlotymi floresami oraz wizerunkami św. Piotra i Pawla w górne] części. Prawa ręka z pierścieniem rybaka uniesiona do błogosławienia. Na odwrccie płótno w dwóch miejscach podklejane. Tamże napis: „P[apiez] Klemens XI. 1720”. Tło ściemnione. I poł. XVIII w. Szkoła wloska.

\section{0}

Relikwiarz $\mathrm{z}$ wizerunkiem $\mathrm{Ma}$ donny z Dzieciątkiem, z typu pięknych Madonn Czeskich, deska. Wymiary awersu w całości $45 \times 53,3 \mathrm{~cm}$; wymiary obrazu bez relikwiarza $18,5 \times 26 \mathrm{~cm}$; wymiary rewersu $\mathrm{z}$ rama $44,7 \times 52,5 \mathrm{~cm}$; wymiary bez ramy $30,5 \times 38,2 \mathrm{~cm}$. Tempera.

Pólpostać $w$ pozycji frontalnej, z Dzieciątkiem na rękach. Głowa Mađonny lekko przechylona $w$ kierunku Dzieciątka: Na głowie piękna, szeroka gotycka korona $z$ ornamentem, na gruncie wytłaczanym i złoconym. Dzieciątko owinięte białą pieluszką, opadającą z lewej strony, prawa rączka wzniesiona z gestem blogosławienia, lewa wyciągnięta przed siebie. Ton karnacji naturalny (jasnoróżowy), suknia Madonny niebieska (błękit górski), $z$ odcieniem zielonym i zieloną podszewką płaszcza. Włosy Dzieciątka ciemnoblond. Tło zlocone $z$ grawerowanym ornamentem złoconym. Duże ubytki $w$ prawym górnym narożniku i małe $w$ obu dolnych.

Wokoło zwierciadła znajduje się podwójny rząd kwadratowych wgłębień w desce, wyłożonych białym jedwabiem (pierwszy rząd) i czerwonym (drugi rząd) $z$ relikwiami osób lub miejsc świętych. Paski pergaminowe na relikwiach posiadają oryginalne gotyckie napisy. Wyściólki i ozdoby $\mathrm{z}$ folii pochodzą z XVIII w.

Wykaz relikwii:

1. S. Bartholomei a[postoli]

2. S. Augustini episcopi

3. S. Karoli imperatoris

4. S. decem milia militum

5. De sepulcro s. Lazari

6. S. Materni

7. S. Cristofori martyris

8. S. Valentyni

9. S. Cosme et Damiani

10. S. Agnetis virginis

11. De mensa Domini

12. S. Floriani martyris

13. S. Venceslai martyris

14. S. Fabiani martyris

15. S. Jodoci presbyteri
16. De sepulcro G[eatae] V[irginis]

17. S. Dorothee virginis

18. S. Cecilie virginis

19. S. decem milia militum

20. S. Sylvestri pape

21. S. Vitalis martyris

22. S. Proculiani martyris

23. De loco transfigurationis Xristi

24. De loco ubi Abraham tres vidit et unum adoravit

25. De loco nativitatis $\mathrm{S}$. Johannis Baptiste

26. S. Adalberti episcopi

27. S. Donati episcopi

28. S. Margarethe virginis 
29. S. Sabini martyris

30. De loco ubi Deus dat legem Moysi

31. Plurimorum sanctorum

32. S. Stanislai episcopi

33. De sepulcro Domini

34. S. Alexandri episcopi

35. De loco orationis Jesu in orto

36. Plurimorum sanctorum

37. S. Ursule virginis

38. S. Remigy episcopi

39. S. Benedicti abbatis

40. De manna Domini

41. S. Pollicee virginis(?)

42. (Dolny napis zakryty górnym)

43. S. Marie Magdalene

44. De sepulcro $\mathrm{s}$. Jeronimi

45. S. undecim milia virginum

46. S. undecim milia virginium

47. S. Pancraty
48. S. Eustachy martyris.

49. S. Lazari episcopi

50. S. De sepulcro B[eatae] V.[irginis]

51. De mensale Domini

52. S. Sebastiani martyris

53. S. Symonis et Jude ap[ostolorum]

54. S. S. Karoli imperatoris

55. S. Johannis Baptiste

56. S. Nicolai episcopi

57. De statua Domini

58. S. Petrus et Paulus

59. De sepulcro s. Katharine

60. S. Barbare virginis

61. S. Maurycy martyris

62. S. Donati episcopi

63. S. Mathei evangeliste

64. S. Georgy martyris

65. S. Sigismundi

$\mathrm{Na}$ odwrocie deski znajduje się napis proweniencyjny w owalu wykonany czarną farbą: „XPani - Jagodzieński - Kunegunda - ten relikwiar.

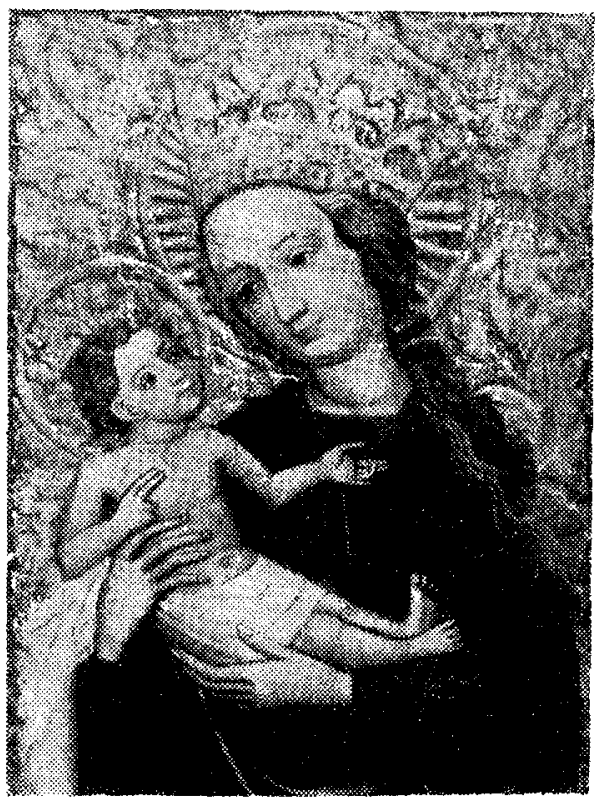
Jakub Michalski. Malarz - R.P. 1728". Przełom XIV/XV w. (około 1420 r.). Gotyk.

Obraz dwukrotnie przemalowano, w XVIII w. (tłusta tempera) i prawdopodobnie $w$ pierwszej połowie XIX w. (olej). Wtedy to dodano drewnianą listewke. Odkrywki wykonane w kilku miejscach na odwrocie deski, pozwalają przypuszczać, że była w kolorze czerwonym. Prawdopodobnie na ugrowym tle był napis, a w narożnikach zielony ornament roślinny.

W r. 1964 konserwację przeprodziła Jadwiga Śliwińska z Muzeum Narodowego w Krakowie. Euszczące się brzegi podściólki kredowej zostały wzmocnione kleikiem skórnym. Brakujący narożnik w prawym górnym rogu został uzupełniony. Obraz odczyszczono $\mathrm{z}$ brudu i zdjęto obie późniejsze farby. Odkryto białą chustę w lewym dolnym rogu. Pod niebieską farbą płaszcza Madonny odkryto górski błękit $\mathrm{z}$ ođcieniem zielonym. Zniknęła czerwona suknia Madonny ukazując zieloną podszewkę. ,Z oryginalnego złota zachowały się tylko ślady". W XVIII w. zostalo ono „przeciągnięte żółtym pulmentem a następn przezłocone brązem w proszku”. Na zakończenie pracy wykonano drobne punktowanie akwarelą i obraz zawerniksowano.

Bibliografia: AKK, rkps - Dokumentacja konserwatorska dla relikwiarza OO. Kapucynów w Krakowie. Wykonana przez Jadwigę Sliwińską dnia 25. VI. 1964. 


\section{1}

Młody mężczyzna $z$ mieczem $w$ oknie (Sirai Sinhachi), $24 \times 35,3 \mathrm{~cm}$, drzeworyt barwny na papierze (druk zwany nishikie). Autor: Utagawa Kunisada (Toyokuni III 1786-1864). Ok. r. 1850. Sygnatura: Ichiyusai Toyokuni. Obok sygnatury dwa stemple cenzorów: Yonehara i Murata; pod sygnaturą pieczęc wydawcy: Enshuya Hikobei (na białym tle).

Oprac.: Mgr Zofia Alberowa i Maria Dzieduszycka z Muzeum Narodowego w Krakowie.

\section{2}

Dwaj mężczyźni w zielonych kapeluszach, $23,5 \times 35,5 \mathrm{~cm}$, drzeworyt barwny na papierze (druk zwany nishikie). Po lewej stronie u góry, na czerwonym kartuszu napis: Fuwa (imię własne). Obok każdej postaci, na czerwonym tle, napisy - po lewej: Nagoya Sanzo (imię własne); po prawej: Fuwa Tomosuke Tokukado (imię własne). Jest to przypuszczalnie scena z dramatu. Autor: Utagawa Kunisada (Toyokuni III 1786-1864). Ok. 1852. Sygnatura: Ichiyusai Toyokuni. Nad sygnaturą dwa stemple cenzorów: Muramatsu i Fuku. Obok sygnatury stempel z datą: rok 1852 (rok szczura). Prostokątny stempel wydawcy: Yebisuya.

Oprac.: Mgr Zofia Alberowa i Maria Dzieduszycka z Muzeum Narodowego w Krakowie.

\section{3}

Starzec siedzący pod kwitnącym drzewem i mężczyzna z parasolem, $50 \times 35 \mathrm{~cm}$, drzeworyt barwny na papierze (druk zwany nishikie). Scena z dramatu. Autor: Utagawa Kunisada (Toyokuni III 1786-1864), ok. r. 1850. Sygnatura po lewej stronie: Kochoro Toyokuni, po prawej, na drugiej planszy: Ichiyusai Toyokuni. $\mathrm{Na}$ obu planszach stemple cenzorów Yonehara i $\mathrm{Mu}-$ rata oraz pieczęc wydawcy: Ue Kin. Na planszy prawej, przy jej lewym brzegu, nazwisko rytownika: Takumi Fusajiro.

Oprac.: Mgr Zofia Alberowa i Maria Dzieduszycka z Muzeum Narodowego w Krakowie.

\section{4}

Dwaj męźczyźni w zielonych kapeluszach oraz dwie kobiety, $50 \times 35 \mathrm{~cm}$, drzeworyt barwny na papierze (druk zwany nishikie). Scena z dramatu teatralnego. Autor: Utagawa Kunisada (Toyokuni III 1786-1864), z r. 1854. Sygnatura na obu planszach: Toyokuni. Obok sygnatury stempel cenzora "aratame" z datą (6 miesiąc roku tygrysa $=1854)$ i pieczęć wydawcy (Yushima, Yuzima).

Oprac.: Mgr Zofia Alberowa i Maria Dzieduszycka z Muzeum Narodowego w Krakowie.

\section{5}

Mężczyźni we wnętrzu domu, scena z rozlaną czarką, $49,5 \times 35 \mathrm{~cm}$, drzeworyt barwny na papierze (druk zwany nishikie). Autor: Utagawa Kuniyoshi (Ichiyusai 1797-1861), drzeworyt wydany pomiędzy r. 1848 a 1853. Sygnatura na obu planszach: Ichiyusai Kuniyoshi. Nad sygnatura stemple cenzorów: Muramatsu i Fuku. Na planszy prawej pieczęć wydawcy Isekane.

Oprac.: Mgr Zofia Alberowa i Maria Dzieduszycka z Muzeum Narodowego w Krakowie. 


\section{6}

Popiersie mężczyzny, 23,3 X $17 \mathrm{~cm}$, drzeworyt na papierze (druk zwany nishikie). Autor: Utagawa Kuniyoshi (Ichiyusai 1791-1861), r. 1852. Sygnatura: Ichiyusai Kuniyoshi. Po lewej stronie stemple dwóch cenzorów: Murata i Kinugasa. U dołu pieczęć wydawcy Yamaguchiya Tobei. Pod stemplami cenzorów stempel $\mathrm{z}$ datą ( 8 miesiąc roku szczura $=1852$ ).

Oprac: Mgr Zofia Alberowa i Maria Dzieduszycka z Muzeum Narodowego w Krakowie.

\section{7}

Portret męzczyzny na tle krajobrazu, $24 \times 35,2 \mathrm{~cm}$, drzeworyt barwny na papierze (druk zwany nishikie). W prawym, górnym narożniku nazwa serii i tytuł planszy (nieodezytane). Autor: Utagawa Kuniyoshi (Ichiyusai 1797-1861). Sygnatura: Ichiyusai Kuniyoshi. Po lewej dwa stemple cenzorów: Wataru i Makin. Poniżej stempel z datą (5 miesiąc roku szczura $=$ r. 1852) oraz pieczęć wydawcy (niezidentyfikowana).

Oprac.: Mgr Zofia Alberowa i Maria Dzieduszycka z Muzeum Narodowego w Krakowie.

\section{8}

Kobieta i mężczyzna na tle krajobrazu, podczas deszczu, 24,5 $\times 35,3 \mathrm{~cm}$, drzeworyt barwny na papierze (druk zwany nishikie). W prawym, górnym narożniku nazwa serii i tytuł planszy (nieodczytane). Autor: Utagawa Kuniyoshi (Ichiyusai 1797-1861), r. 1852. Sygnatura: Ichiyusai Kuniyoshi. Po lewej stronie stemple cenzorów: Yonehara i Watanabe. Po lewej, u dołu nazwisko rytownika i wydawcy niezidentyfikowane). Obok sygnatury stempel $\mathrm{z}$ datą $(1 \mathrm{miesiąc}$ roku szczura $=1852)$.

Oprac.: Mgr Zofia Alberowa i Maria Dzieduszycka z Muzeum Narodowego w Krakowie.

Uwaga: Około 10 drzeworytów japońskich wspomnianych autorów skradziono z. Biblioteki Klasztoru OO. Kapucynów w Krakowie w r. 1963.

\section{9}

Pan Jezus w Getsemani, $48 \times 68 \mathrm{~cm}$, płótno, olej. W pozycji klęczącej, z rękami złożonymi do modlitwy, wsparty o kamień, w żóltoniebieskiej szacie $i$ fioletowym plaszczu. Tlo ciemnozielone, $z$ prawej strony na horyzoncie trzy krzyże. I poł. XX w.

\section{0}

Pan Jezus w Getsemani, 67,5 ×97 cm, płótno, olej. Na tle pochmurnego nieba i ciemnego ogrodu, w pozycji klęczącej, z rękami opartymi o kamień, $\mathrm{z}$ glową uniesioną $\mathrm{w}$ górę, skąd spływa struga promieni, w niebieskiej szacie i czerwonym płaszczu. I pol. XX w

\section{1}

Sw. Feliks z Cantalice, kapucyn, $44 \times 58 \mathrm{~cm}$, płótno, olej. Kopia wykonana z figury (już nieistniejącej) oltarza św. Feliksa w kościele OO. Kapucynów w Krakowie. W pozycji stojącej, frontalnej, w habicie kapucyńskim i płaszczu, z Dzieciątkiem Jezus w obu rękach. Dzieciątko w niebieskiej sukience, prawa rączka podniesiona do błogosławienia. $Z$ obu stron postaci po dwie białe lilie. Pocz. XX w.

\section{2}

Matka Boska Szkaplerzna, $55 \times 69 \mathrm{~cm}$, płótno, olej. W pozycji stojącej, frontalnej, z Dzieciątkiem Jezus na prawej ręce, w koronach. Madonna 
w jasnoczerwonej sukni i niebieskim płaszczu. Dzieciątko w białej sukience, w obu rękach trzyma szkaplerze, które Matka Boża podtrzymuje lewą ręką. Tło jasnoniebieskie. I poł. XX w.

\section{3}

Serce Jezusowe, $49,3 \times 64,5 \mathrm{~cm}$, płótno, olej. Pólpostać, w białej szacie i purpurowym płaszczu, prawa ręka wyciągnięta przed siebie, lewa odsłania szatę i wskazuje gorejące Serce. Tło ciemne. I poł. XX w.

\section{4}

Scena z zycia Swięte Rodziny, na feretronie $z$ jednej strony, $40,5 \times 68 \mathrm{~cm}$, blacha, olej. Matka Boża w różowej sukni 1 niebieskim płaszczu, w pozycji siedzące przy kądzieli, przędzie len. Św. Józef piłuje deskę. Pan Jezus młoten i dłutem wybija otwór w drewnie. Tło zielone. II poł. XIX w.

\section{5}

Matka Boska Częstochowska, na feretronie z drugiej strony, $40,5 \times 68 \mathrm{~cm}$, blacha, olej. Madonna z Dzieciątkiem, w złotych koronach, w niebieskiej sulkni z czerwoną podszewką; Dzieciątko w rózowej sukience. U dolu napis: „Pod Twoją Obronę uciekamy się”. Tło zólte. II poł. XIX w.

\section{6}

Portret o. Kosmy Lenczowskiego, $36 \times 47 \mathrm{~cm}$, rysunek ołówkiem na papierze. W pozycji siedzącej, trzy czwarte w lewo, ręce oparte na fotelu. $Z$ lewej fragment biblioteki, z prawej u dołu sygn.: „Scipio" [del Campo]. Ok. r. 1954.

\section{7}

Chryistus ukazujący ranę prawego boku, $68 \times 98,5 \mathrm{~cm}$, płótno, olej. Półpostać, w cierniowej koronie, trzy czwarte w prawo, obu rękami otwiera i wskazuje ranę prawego boku; purpurowa szata opadająca z lewego ramienia obnaża

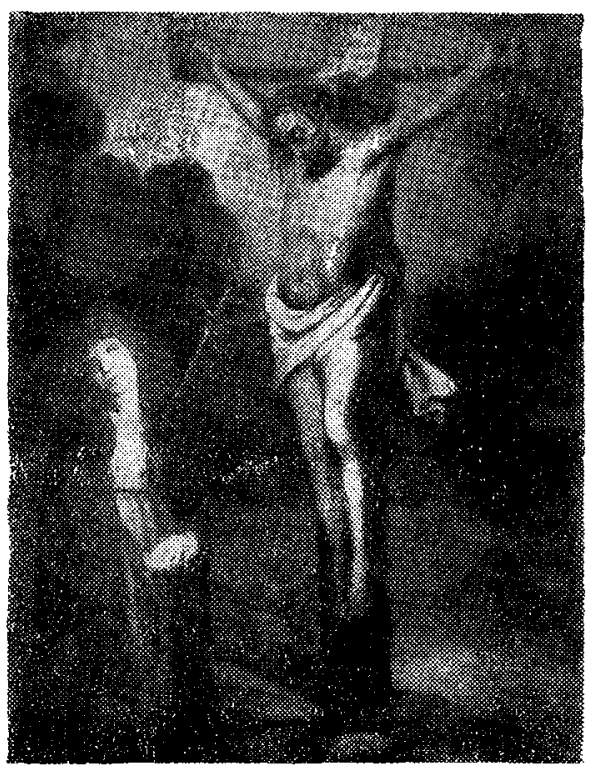
ciało Jezusa. Usta otwarte $\mathrm{z}$ bólu. Tło ciemne. U dołu na tle purpurowej szaty napis na białej szarfie: ,VIENI DE VIENI O PECATORE EVORATO | DENTRO AL COSTATO MIO DENTRO AL MIO ! VERDAI COME PER TE ARDE DI AMORE ! IL TVO AMANTE O IESU TVTTO PIACATO". Poniżej na szerokiej białej szarfie tlumaczenie tekstu: „PRZYJDZ - $\mathrm{ACH}-$ PRZYJDZ - GRZESZNIKU - DO - RANY SERCA | MOJEGO ZOBACZYSZ - JAK - GORE$\mathrm{JE}$ - MIEOŚCIA - KU - TOBIE - KOCHAJACY - CIE - JEZUS - WŁÓCZNIA - DLA CIEBIE PRZEBITY". I pol. VIII w. Barok. 278

Ukrzyzowanie z Matką Bolesną, $47,5 \times 65 \mathrm{~cm}$, deska, olej. Na krzyżu 
Chrystus ukrzyżowany, z głową opuszczoną w dół, cała postać skierowana trzy czwarte w lewo, białe perizonium opada faldami z prawej strony. $Z$ lewej strony krzyża klęczy Matka Boska, w różowej sukni i ciemnobrązowym płaszczu, z rękami złożonymi do modlitwy, miecz wbity w jej serce. Tło jasno- i ciemnobrązowe. XVII w. Barok.

\section{9}

Św. Serafin z Montegranaro, kapucyn, $18 \times 24 \mathrm{~cm}$, deska, olej. Półpostać, trzy czwarte $w$ lewo, w brązowym habicie, prawie z łysą głowa, $z$ siwa brodą, w prawej ręce, uniesionej nieco w górę, trzyma krzyż misyjny i różaniec a !ewą wskazuje na nie. Tło popielate. XVIII w. Późnobarokowy. Szkoła wloska. Kupiony 4. V. 1964 w Księgarni Katolickiej przy ul. Mikołajskiej w Krakowie. Pochodzi ze zbiorów dra Janusza Kowalskiego (Kraków, ul. Długa $29 \mathrm{~m}$. 4).

Bibliografia: P. Cuthbert OMCap.: I Cappucini. Un contributo alla storia della controriforma. Traduzione dall'originale inglese di P. Arsenio da S. Agata Feltria OMCap. Faenza 1930 s. 384. Na tej stronie znajduje się rycina, zapewne $z$ XVII1 w., według której, z bardzo małymi odchyleniami, został wykonany powyższy portret.

\section{0}

Św. Franciszek Salezy, $21 \times 25 \mathrm{~cm}$, płótno naklejone na tekturę, olej. Popiersie $\mathrm{w}$ pozycji frontalnej, en face, $\mathrm{z}$ ruda brodą, w zóltej infule i takiej kapie $z$ czerwonym podbiciem; w prawej ręce pastorał, lewa spoczywa na sercu. Tło zielone. $Z$ prawej, na kolumnie $z$ fragmentem kotary, sygn.: „S. FRANCISCUS | SALESIUS EP[ISCOPUS] | 1887. | JKR (?)”.

\section{1}

Wizja św. Antoniego z Padwy, $8,9 \times 14 \mathrm{~cm}$, miedzioryt. Swięty w pozycji klęczącej, trzy czwarte w lewo, obejmuje obu rękami objawione wśród chmur Dzieciątko Jezus, z białą lilią w prawej raczce. $\mathrm{Z}$ lewej aniołek, z prawej, w górze dwie uskrzydlone główki aniołków. Podpis: „S. Antonio di Padova”. Sygn. z lewej, u dolu: „Franc[iscus] Manno inv[enit] et del[ineavit]”. z prawej, u dolu: „Alexander Mochetti sculp[sit]”. I pol. XIX w.

\section{RZEŹBY I PEASKORZEŹBY}

\section{1}

N. Maria P. Łaskawa, stojąca obecnie na kolumnie u wylotu ul. Jagiellońskiej przy Plantach, a przed r. 1941 u wylotu ul. Kapucyńskiej; wys. figury $207 \mathrm{~cm}$, wys. kolumny $438 \mathrm{~cm}$, rzeźba pełna w kamieniu. W pozycji frontalnej, stojącej $w$ koronie na kształt Batorego; $w$ prawej ręce dzierży berło, w lewej trzy strzały, w tym dwie złamane. W rozwianej szacie, z lewej strony $u$ dołu putto, a u stóp, w obłokach dwie uskrzydlone główki aniołków. Dzieło Jana Krzyżanowskiego z r. 1761. Barok.

Właściwa historia figury zagubiła się wśród licznych legend. Na podstawie kroniki klasztoru OO. Kapucynów w Krakowie, prawnych właścicieli zabytku, da się stwierdzić następujące fakty. W r. 1795 władze austriackie zarządziły zniesienie cmentarza grzebalnego przy kościele Mariackim. Kapucyni zakupili wtedy figurę, która przedtem stała na tymże cmentarzu i po odnowieniu umieścili na wysokiej kolumnie, na placu przed swoim kościołem (dziś u wylotu ul. Kapucyńskiej), dokładnie w tym miejscu, w którym stała dotychczas figura św. Franciszka, wskazująca miejsce klasztoru OO. Reformatów, spalonego w czasie wojen szwedz- 
kich. Figura dotrwała na nowym miejscu aż do okupacji hitlerowskiej, kiedy to stała się celem licznych manifestacji patriotycznych. Zapewne stało się to $\mathrm{m}$. in. powodem przeniesienia figury we wrześnıu $1941 \mathrm{r}$. na inne miejsce. Przy tej okazji rzeźbiarz Napadło poddał figurę konserwacji.

Bibliog r afia: AKK, rkps HCC, I s. 268, 276-277, II s. 19 (inna wersja historii figury). - APK, rkps - Br. E. Chmi e l: Kronika s. 57 (Opis manifestacji patriotycznych przed figurą w r. 1941; s. 59: Usunięcie figury). - APK, rkps Br. T. K ow a lik: Rozmaitości s. 191. - K. S o c z y ński: Starożytności i pomniki Krakowa. Kraków $1846 \mathrm{~s}$. 31. - A. G r a b ow ski: Skarbniczka naszej archeologii, obejmująca średniowiekowe pomniki wojennego budowinctwa Polaków, wiadomości do dziejów sztuk pięknych w Polsce oraz wspomnienia z naszej przeszłości. Lipsk $1854 \mathrm{~s} .164$. - J. M ą c z y ń s ki: Kilka podań i wspomnień krakowskich Kraków 1855 s. 39 . - W. P a c zkow ski: Pamiętnik [...] porucznika dawnej gwardii cesarsko-francuskiej. Spısane w r. 1845. Zytomierz 1861 s. 20. - O. W. Nowakowski: Statua Najśw. Maryi Panny przed kościołem OO. Kapucynów w Krakowie. Ustęp z czasów Konfederacji Barskiej w Krakowie. Wyd. 2. Kraków 1894. - O. W. Now a k o w ski: O cudownych obrazach w Polsce s. 299-300. „Krakowianin". Dziwna historia statuy N. Panny Marii przed kościołem OO. Kapucynów w Krakowıe. Kalend. francesz. na rok Pański 1930. s. 88-96. - M. S k r ud 1 i k: Królowa Korony Polskiej s. 172-174. - S. M r óz: Matka Boska wędruje Ilustr. Kur. pol. R. 2: $1941 \mathrm{nr} 39$ (reportaż z fotografiami). - Usunięcie figury. Wojenna katol. Agencja pras. KAP. Warszawa R. 1: $1943 \mathrm{nr} 1$ s. 17: „Z Krakowa donoszą, ıż figura Matki Boskiej znajdująca się przy ulicy Krupniczej została przez Niemców usunięta". Oczywiście chodzi tutaj o figurę z ul. Kapucyńskiej. O. K. Gad a c z: Inwentarz Archiwum s. 109, 116. - K. G a d a z: Refleksje o zabytkach. Tyg. powsz. R. 16: $1962 \mathrm{nr} 13$ s. 5.

\section{2}

Ŝw. Jan Nepomucen, w zewnętrznym narożniku kaplicy Loretańskiej przy cmentarzu z prawej strony, wys. figury $164 \mathrm{~cm}$, wys. cokołu $175 \mathrm{~cm}$, rzeźba pełna z twardego pińczowskiego piaskowca. W pozycji frontalnej, stojącej, glowa $z$ długimi włosami uniesiona $w$ górę. W sutannie, mucecie $z$ trzema frędzlami oraz ozdobną koronką u dołu. Prawa ręka wzniesiona w górę, niegdyś dzierżyła krzyz, lewa wysunięta w bok, dawniej trzymała palmę męczeńska, atrybut ikonograficzny świętego. Wyrzeźbił „Statuarius Germanus" za 30 dukatów. Ufundowal ją ks. Maciej Łubieński, kanonik krakowski, który ją téz poświęcił 9 listopada $1745 \mathrm{r}$.

Konserwacja. W okresie Konfederacji Barskiej figura została częściowo uszkodzona od pocisków nieprzyjacielskich. Dlatego w r. 1790 kamieniarz uzupełnil rękę z krzyżem. Ponieważ statua znajdowała się nad wodami podskórnymi, na skuteir wilgoci odpadła $z$ czasem ręka $z$ krzyżem $i$ druga $z$ palmą. W r. 1817, kosztem Antoniego Kuczkowskiego, obywatela miasta Krakowa, została poddana gruntownej konserwacji. W r. 1818 statua została ozdobiona przez malarza kosztem ks. Jerzego Mieroszewskiego, kanonika krakowskiego. W r. 1916 kamieniarz Markiewicz znów odnowił figurę.

Figura świętego jest wypełnjeniem ślubu konwentu krakowskiego z r. 1744. Kaplica Loretańska, z powodu wilgoci, groziła wtenczas zawaleniem. Architekt Placidi orzekł, że $w$ pierwszym rzędzie należy wzmocnić fundamenty. Do pracy przystąpiono natychmiast. W tym miejscu, gdzie obecnie wznosi się statua, natrafiono na obfite źródło wody, którego nie umiano powstrzymać. Wtedy gwardian klasztoru wraz z zakonnikami odprawił nowennę do M. B. Loretańskiej i przyrzekł postawić figure św. Janowi Nepomucenowi, patronowi od powodzi i M. B. Loretańskiej. Wkrótce woda przestała płynąc a prace spokojnie doprowadzono do końca. $\mathrm{Na}$ pamiątkę wydarzenia na cokole figury umieszczono chronostych: 


\author{
InIeCtVs FVnDIs \\ IVnDos \\ patronVs abVnDIs \\ protegat ILLaesos \\ Vt pIa \\ Vota petVnt
}

B ibliog r f 1 a: AKK, rkps HCC, I s. $84-85,229,373,379$; IV s. 123. A.KK, rkps 39: Inwentarz z r. $1821 \mathrm{k} .17$, 43v. Statua byla wtedy nakryta daszklem blaszanym; Inwentarz z r. 1858 k. 100v. - AKK, rkps 40: Inwentarz z r. 1875 s. 8. - APK, rkps 306: Br. T. Kow a li k: Rozmaitości s. 74. Autor polemizuje z A. Chmielem, który twierdzil, że statua św. Jana Nepomucena sprzed kościoła OO. Karmelitów została przeniesiona przed kościół OO. Kapucynów. Po długim badaniu i szukaniu figury po Krakowie, odnalazł ją br. Teofil przed kościołem OO. Misjonarzy na Nowej Wsi. - APK, rkps - O. P. Koch án $\mathrm{ki}$ : Kościół Zwiastowania s. 32, 44. - O. W. N ow a kow s ki: Pamiątka s. 14. O. Florian [Janocha] (Loretto s. 16) mylnie twierdzi, że cudowne zdarzenie miało miejsce w r. 1712. - O. A. Wojnar (Polski Loret s. 55) powtarza błędnie za o. Florianem.

3

Matka Boska Loretańska, w niszy na zewnątrz kaplicy Loretańskiej od strony cmentarza kościelnego, wys. figury $129 \mathrm{~cm}$, wys. postumentu $35 \mathrm{~cm}$, rzeźba pełna $z$ piaskowca ofiarowanego przez jezuitów od św. Macieja w Krakowie. W pozycji frontalnej, stojącej, z Dzieciątkiem Jezus na lewej ręce, w złoconych koronach. Suknia ozdobiona kwiatami oraz stylizowanymi liśćmi. Dzieciątko prawą rączkę unosi ku górze gestem błogosławienia, w lewej trzyma jabłko $z$ krzyżem. Z lewej strony, w dole, widoczne poważne pęknięcie. $\mathrm{Na}$ postumencie herb Rawicz, mocno zatarty. Wykonal ją „Statuarius Germanus" w r. 1745. Barok. Figura została odnowiona w r. 1818 kosztem Józefa Stawińskiego, organisty z parafii św. Szczepana na Piasku. W r. 1916 kamieniarz Markiewicz ponownie odnowił rzeźbę. Historia figury podobna jak św. Jana Nepomucena.

B ibliografia: AKK, rkps HCC, I s. 84-85, 379; IV s. $123 .-$ AKK, rkps 39: Inwentarz z r. 1821 k. 17, 43v, 62; Inwentarz z r. 1858 k. 100v. - AKK, rkps 40: Inwentarz z r. 1875 s. 8. - APK, rkps - Br. E. Chmiel: Kronika s. 350. APK, rkps - O. P. Ko chańs ki: Kościól Zwiastowania s. 33-34. - APK, rkps 306: Br. T. Kow a 1ik: Rozmaitości s. 195. - O. W. Now ak ow ski: Pamiątka s. 14-15. - O. Florian [J a n o ch a]: Loretto s. 16-17. - O. A. Wojnar (Polski Loret s. 55) mylnie, za o. Florianem, umiejscawia cudowne wydarzenie w początkach fundacji kaplicy Loretańskiej.

\title{
4
}

Matka Boska Loretańska, w niszy na zewnatrz, naprzeciw bocznych drzwi wejściowych od strony póknocnej kaplicy Loretańskiej, wys. figury $z$ postumencikiem $73 \mathrm{~cm}$, rzeźba pełna z kamienia. W pozycji frontalnej, stojącej, z Dzieciątkiem Jezus na lewej ręce, w koronach. Suknia ozdobiona trzema półksiężycami w pozycji poziomej, pasem poprzecznym z różnymi zdobnikami, w dole pięć gorejących serc. Dzieciątko prawą rączkę wznosi do błogosławienia, w lewej trzyma jabłko z krzyżem. Dzieło rzeźbiarza Bogusława Langmana z r. 1959.

Bibliografia: APK, rkps - Br. E. Chmiel: Kronika s. 219.

\section{5}

Św. Franciszek z Asyzu, z prawej strony nad przedsionkiem kościelnym, wys. figury $125 \mathrm{~cm}$, rzeźba pełna z kamienia pińczowskiego. W pozycji frontalnej, stojącej, z głową lekko opuszczoną w dół, lewa noga lekko odsunięta do tyłu, ręce złożone na krzyż na piersiach. W habicie kapucyńskim, z paskiem 
i rózańcem. Dzieło Stanisława Majchrzalka z Krakowa, wykonane w r. 1925 za $600 \mathrm{zł}$.

Bibli ografia: AKK, rkps HCC, I s. 205. Na tej samej stronie jest również wlepiona luźna kartka z tytulem: „Wydatki na restauracje kościola i kaplicy Loret[ańskiej]”, i tu widnieje pozycja: „Artysta rzeźbiarz Majszak(?) - figury św. Franciszka i św. Antoniego - $1200 \mathrm{zl}$ ". - AKK, rkps $89 \mathrm{cz} .1$ : Kwity 1909-1931 k. 84-90. - APK, rkps - O. P. K o ch a ń ski: Kościół Zwiastowania s. 52.

\section{6}

Św. Antoni Padewski, z lewej strony nad przedsionkiem kościelnym, wys. figury $125 \mathrm{~cm}$, rzeźba pełna z kamienia pińczowskiego. W pozycji frontalnej, stojącej, z głową opuszczoną lekko w dól, prawa noga lekko odsunięta do tyłu. $\mathrm{Na}$ lewej ręce Dzieciątko Jezus. W habicie kapucyńskim, z paskiem i rózańcem. Wykonał w r. 1925 za 600 zł rzeźbiarz Stanisław Majchrzak z Krakowa.

\section{7}

Aniol, na trójkątnym przyczółku kaplicy Loretańskiej, wys. figury okoko $160 \mathrm{~cm}$, wys: postumentu ok. $40 \mathrm{~cm}$, rzeźba pełna z kamienia. W pozycji frontalnej, stojącej, górny korpus lekkko przechylony do tyłu, ręce złożone na krzyż na piersiach. I poł. XVIII w. Barok. Na pozostałych dwóch przyczółkach stoją podobne anioły.

Bibliografia: AKK, rkps 39: Inwentarz z r. 1821 k. 24, 69; Inwentarz z r.1871 k. 146. - AKK, rkps 40: Inwentarz z r. 1875 s. 14. - APK, rkps O. P. Ko chański: Kościół Zwiastowania s. 28. - O. Zagórowski: Architekt Kacper Bażanka około $1680-1726$ r. Biul. Hist. Szt. R. 18: $1956 \mathrm{nr} 1$ s. 100.

\section{8}

Krzyż na tabernakulum wielkiego ołtarza, wys. korpusu $13 \mathrm{~cm}$, rozpiętość rąk $10,5 \mathrm{~cm}$, rzeźba pełna $\mathrm{z}$ kości słoniowej. Głowa przechylona w lewo, na biodrach perizonium, nogi oddzielnie przybite do belki krzyżowej. W górnej części podłużnej belki tabliczka $z$ kości słoniowej z inicjałami INRI, w dolnej dwa skrzyżowane piszczele. Dzieło o. Franciszka z Pescji, Giovan Pietro Marchi, kapucyna z r. 1719.

B ibliog rafia: AKK, rkps HCC, I s. 31. - APK, rkps - O. K. G ad a cz: Historia klasztoru s. 22. - APK, rkps - O. P. K ochański: Kościól Zwiastowania s. 71 . - O. W. Now a kow ski: Pamiątka s. 25. W r. 1895 krzyż ten znajdował się na ołtarzu św. Antoniego.

\section{9}

N. Maria P. Niepokalanie Poczęta, zwana popularnie Tułaczką, w niszy oltarza z prawej strony nawy, wys. ok. $138 \mathrm{~cm}$, rzeźba pełna $z$ drzewa lipowego. W pozycji frontalnej, stojącej na kuli ziemskiej, jedną stopą wspiera się o srebrny księżyc, a drugą depce węża. Wokoło glowy z czarnorudymi włosami metalowa aureola $\mathrm{z} 12$ gwiazdkami. Głowa przechylona w lewo i lekko pochylona w dók, prawa ręka opuszczona w dók, lewa uniesiona nieco w górę. Suknia biała przepasana białą szarfa, płaszcz niebieski. Nogi bose. I poł. XIX w. Późnobarokowa.

Do r. 1899 statua Matki Boskiej stała w zewnętrznej niszy narożnika pierwszego piętra kamienicy Antoniego Suskiego, przy ul. Grodzkiej i Pl. Dominikańskim. Prawdopodobnie była godłem domu. W czasie pożaru Krakowa w 1850 r. ocalała. Ale w r. 1899 była tak zniszczona, że właściciel postanowił ją spalić a $\mathrm{w}$ jej miejsce umieścić statuę z kamienia. a prośbę o. Floriana Janochy, pođarował ją klasztorowi OO. Kapucynów Po konserwacji ustawiono ją najpierw 
na ołtarzu św. Feliksa, potem przenicsiono na ołtarz św. Antoniego i tu stała przez 2 i pół roku. W końcu usunięto ją na korytarz kaplicy Loretańskiej. Z okazji jubileuszu 50-lecia ogłoszenia dogmatu Niepokalanego Poczęcia N. M. Panny uroczyście przeniesiono figurę na wielki ołtarz, na którym stała przez rok jubileuszowy. Dnia 8 grudnia 1904 umieszczono ją w obecnym oltarzu. Konserwację figury przeprowadził w r. 1899 malarz Mikulski, a malarz Mikolajski wykonał polichromię. W 1. 1937-1938 malarz K. Puchała ponownie pomalował statuę.

Bibliografia: AKK, rkps HCC, III s. 316 , 334. - APK, rkps 148: Materiały. Tułaczlka (historia figury M. B. w krakowskım kościele OO. Kapucynów) k. 55-56. - APK, rkps - Br. E. Ch miel: Kronika s. 8, 278. - APK, rkps O. P. K o c h a ń s ki: Kościół Zwiastowania s. 58-59. - APK, rkps 306: Br. T. K owa lik: Rozmaitości s. 198-199. Autor był zakrystianem i doskonale znał historię figury. W opisie oparliśmy sıę na relacji o. Floriana (APK, rkps 148). - A. S t erns ch u s: Godla domów krakowskich. Rocz. krak. R. 2: 1899 s. 18. - Reprodukcja litograficzna, wykonana przez M. Salba a wydana przez o. Floriana z okazji jubileuszu w r. 1904, zawiera na odwrocie historię figury. - O. Florian [ $\mathrm{J}$ a $\mathrm{n}$ o c h a]: Wotywa jubileuszowa. Kraków 1904. Reprodukcja chromolitograficzna figury przed kartą tytułową. - O. Florian [J a n o cha]: Serafickie nabożeństwo majowe Niepokalanie Poczętej Najświętszej Pannie Maryi. Kraków 1904. Reprodukcja figury przed kartą tytułową. - O. K. G a d a c z: Inwentarz Archiwum s. 90.

10

Sw. Józef z Dzieciątkiem Jezus, w niszy oltarza z lewej strony nawy, szer. $102 \times$ wys. $177 \mathrm{~cm}$, rzeźba pełna w kamieniu pińczowskim. W kamiennej niszy stoi święty $w$ pozycji frontalnej, przedstawiony przez artystę jako starzec. Na skronie jego spada bujny splot włosów a na twarzy maluje się niebiański spokój. Zdaje się, ze przed chwilą porzucił pracę a spracowaną dłonią ujął Dzieciątko Jezus w prawą rękę i przytula do serca. Dzieciątko prawą rączkę unosi $w$ górę. Święty w lewej ręce trzyma białą lilię. U dołu, na postumencie, siedzi niewiasta, która tuli się pod płaszcz swego Opiekuna; w prawej ręce trzyma otwartę księgę a lewą złożyła na sercu. Jest to Królowa Polski, która z księgi odczytuje dzieje niewoli i historię męczeństwa narodu polskiego. $Z$ lewej strony, na postumencie, narzędzia ciesielskie, topór, cyrkiel. Jest tam również bukiet róż. Na postumencie napis: „Ad honorem B[eatae] V[irginis] Mariae sumptibus a benefactoribus per tertiarios collectis aedificatum. A. D. 1903" oraz sygnatura: „Comp[osuit] et fecit Thaddaeus] Błotnicki 1903". Poświęcenie ołtarza odbyło się 4 października 1903 r. W r. 1938 odnowiono rzeźbę za cenę $45 \mathrm{zl}$. Barok.

Bibliografia: AKK, rkps HCC, III s. 299, 300, 307. - APK, rkps Br. E. Chmi e l: Kronika s, 277. - APK, rkps - O. P. Ko ch a ́́s ki: Kościót Zwiastowania s. 60. - APK, rkps 177: Album z wycinkami $z$ gazet $\mathrm{i}$ czasopism o działalności duszpasterskiej, społecznej i patriotycznej o. Anioła od r. 19001939 k. 66v. - O. Florian [J a n o c h a]: Szkaplerz czyli Opieka św. Józefa. Wyd. 2. Kraków 1917. Przed kartą tytułowa reprodukcja figury. - L.: Kult św. Józefa w Krakowie. Pod Opieka św. Józefa. R. 1: $1946 \mathrm{nr} 1$ s. 15. - O. K. G a d a c z: Inwentarz Archiwum s. 108.

\section{1}

Ŝw. Antoni Padewski, z lewej strony oltarza św. Antoniego, wys. ok. $124 \mathrm{~cm}$, rzeźba pełna w piaskowcu. W pozycji frontalnej, stojacej w brązowym habicie kapucyńskim, w prawej ręce trzyma Dzieciątko Jezus, w lewej chlebek, który podaje ubogiemu chłopcu, stojacemu przed nim. Wyrzeźbił Romuald Łapczyński z Krakowa. W r. 1938 figurkę odnowiono. Początek XX w. 
Bibliografia: APK, rkps 306: Br. T. K ow a lik: Rozmaitości s. 209. Pierwszy wymienıa nazwisko rzeźbiarza. - APK, rkps - Br. E. C h m i e I: Kronika s. 22. - APK, rkps - O. P. K o ch ań ski: Kościół Zwiastowania s. 68.

Sw. Feliks z Cantalice, kapucyn, w niszy ołtarza św. Feliksa, wys. ok. $160 \mathrm{~cm}$, rzeźba pełna $\mathrm{w}$ kamieniu, kolorowana na jasnobrazowo. W pozycji frontalnej, stojącej $w$ habicie kapucyńskim, z brodą, głowę pochyla nad Dzieciątkiem Jezus, które trzyma przed sobą w obu rękach. Na ramieniu załozona sakwa kwestarska. Wokoło glowy metalowa aureola. $\mathrm{Na}$ małym postumencie napis: DEO GRATIAS. Wy rzeźbił Bogusław Langman z Krakowa. Poświęcenie figury odbyło się 16 maja $1959 \mathrm{r}$.

Bibliografia: AKK, rkps HCC, IV s. 476.

13

Chrystus Ukrzyzowany, w kaplicy Pana Jezusa, wys. korpusu $177 \mathrm{~cm}$, rozpiętość rąk $163 \mathrm{~cm}$, rzeźba pełna drewniana, polichromowana. Glowa opuszczona w dók, przechylona w lewo. Na głowie metalowa aureola i cierniowa korona. Białe perizonium wokoło bioder opada fałdami z prawej strony. XVII w. Barok.

Rzeźba pochodzi z kościoła św. Michała OO. Karmelitów Bosych w Krakowie. Klasztor karmelicki zostak zniesiony w r. 1797 i zamieniony na więzienie, a kościół przeznaczony na kaplicę więzienną. Od 13 listopada 1813 r. obowiązki duszpasterskie w więzieniu spełniali kapucyni. Na prośbę gwardiana klasztoru, o. Rafała, z dnia 2 czerwca 1834 r. Konsystorz Gen. Krakowski i prezydent Senatu W. M. Krakowa wyrazili zgodę na przeniesienie krucyfiksu $z$ kaplicy więziennej do kościoła kapucyńskiego, pod warunkiem, że „ku czci publicznej wystawiony zostanie". Krzyż ten znajdował się w kaplicy, ufundowanej w r. 1676 przez Stanisława Rozrażewskiego. W omawianym okresie wisiał on za wielkim ołtarzem, „w zakątku ukryty". W kościele kapucyńskim został ustawiony w oltarzu dnia 14 lipca $1834 \mathrm{r}$. Przedtem jednak zniszczoną przez wilgoć i korniki rzeźbę poddano konserwacji. Wymieniono ramiona krzyża, a zniszczony korpus z pietyzmem odrestaurował art. mal. Wojciech Kornel Stattler. Srebrną koronę cierniową i promienie nad głową wyzłocił Macıej Bojanowski.

Bibliografia: AKK, rkps HCC, I s. 492-493. - AKK, rkps 38: Dodatek do inwentarza z r. 1834 k. 87v. - AKK, rkps 39: Inwentarz z r. 1858 k. 103. AKK, rkps 40: Inwentarz z r. 1875 s. 28. - Archiwum Kurii Metropolitalnej w Krakowie. Akta $z$ napisem: OO. Kapucyni. List o. Rafała z dnia 2 czerwca 1834 r. do Konsystorza. - APK, rkps - O. P. K o c hańs ki: Kościół Zwiastowania s. 68-69. - Arch. Un. Jag., rkps - J. L a n g m a n: Nieistniejący kościól św. Józefa i św. Michała OO. Karmelitów w Krakowie. Kraków 1947 s. 66. (Praca doktorska w maszynopisie). - O. W. Now a kow ski: Pamiątka s. 19.

Pieta, w antepedium oltarza Chrystusa Ukrzyżowanego, szer. $197 \times 59 \mathrm{~cm}$, plaskorzeźba w drzewie, lakierowana na brąowo. $\mathrm{Na}$ tle wschodzacego słońca, które opromienia całą scenę, Madonna wsparta o fragment belki krzyżowej, w pozycji siedzącej, podtrzymuje w dłoniach głowę Chrystusa zdjętego $\mathrm{z}$ krzyża. $\mathrm{Z}$ obu stron po dwie postacie oddające hold Panu Jezusowi. I pol. $\mathrm{XX}$ w.

Bibliografia: APK, rkps - O. P. Kochański: Kościól Zwiastowania s. 70 . 
Matka Boska Loretańska, w niszy za oltarzem w kaplicy Loretańskiej, wys. $177 \mathrm{~cm}$, rzeźba drewniana, drązona od zewnątrz, głowa Madonny i Dzieciątka prawdopodobnie z wosku. W pozycji stojącej, frontalnej, z Dzieciątkiem na lewej ręce, w koronach. Rzeźba przybrana w suknie, z głowy spływa biały welon. Dzieło o. Franciszka z Pescji, Giovan Pietro Marchi, kapucyna, z r. 1719. Barok.

$\mathrm{Bibliografia:} \mathrm{AKK}$, rkps HCC, I s. 31. - AKK, rkps 39: Inwentarz z r. 1821 k. $24 \mathrm{v}-25 ; 47,69 \mathrm{v}$; Inwentarz z r. 1858 k. $102 \mathrm{v}$; Inwentarz z r. 1872 k. 148. - AKK, rkps 40: Inwentarz z r. 1875 s. 24. - APK, rkps - O. K. G adacz: Historia klasztoru s. 22, - APK. rkps O. P. K och ański: Kościół Zwiastowania s. 71-72. - [A. Kleczkowski] A.: Swięte pamiątki Krakowa s. 417-418. - O. W. Now a k ow ski: Pamiątka s. 22-23. - O. W. Now a kowski: O cudownych obrazach w Polsce s. 301-303. - O. F. J a n o ch a: Loretto s. 24-37. - [O. A. W o j n a r]: Polski Loret s. 56-57.

\section{6}

Aniol, w skarbcu kościelnym, wys. $101 \mathrm{~cm}$, rzeźba drewniana, polichromowana. W pozycji frontalnej, stojącej, $z$ rękami wyciągniętymi w górę, $\mathrm{z}$ glową podniesioną, $z$ dużymi skrzydłami cofniętymi do tylu. W tunice złocistej i takąż przepaską na czole. Dobrze zachowany. I poł. XIX w.

\section{7}

Ornat, w skarbcu kościelnym, wys. $41,5 \mathrm{~cm}$, rzeźba pełna drewniana, bez polichromii. W pozycji kIęczącej, obie ręce wsparte o brodę. Na postumenciku. XX w.

\section{8}

Aniol, w skarbcu kościelnym, wys. $82,3 \mathrm{~cm}$, rzeźba drewniana drążona od zewnątrz, z nową olejną polichromią, pod którą, i od tyłu, zachowała się dawna polichromia $\mathrm{w}$ kolorze niebieskim oraz pozostałość złocistej na skrzydłach. W pozycji stojącej, głowa lekko uniesiona do góry, ręce zlożone na krzyż na sercu, długie włosy. Suknie srebrnozłote z niebieska podszewką, skrzydla pozłacane. $\mathrm{Na}$ małym postumenciku. XVIII w. Barok.

Aniol, w skarbcu kościelnym, wys. $104 \mathrm{~cm}$, rzeźba drewniana, drązona od zewnątrz, z nową polichromią, pod którą zachowana dawna. W pozycji klęczącej, $z$ głową pochyloną, $z$ rękami złożonymi do modlitwy, klęczy na prawym kolanie, lekko zwrócony $\mathrm{W}$ prawo. W tunice srebrnoniebieskiej z złocistymi skrzydłami. XVIII w. Barok.

Anioł, w skarbcu kościelnym, wys. $101 \mathrm{~cm}$, rzeźba drewniana, drążona od zewnątrz, z nową olejną polichromia, dawna zapewne zachowana pod spodem. W pozycji klęczącej, lekko zwrócony $w$ lewo, $z$ rękami złożonymi na krzyz na piersiach. W szacie srebrnej i płaszczu u dołu szaroniebieskim. XVIII w. Barok.

Anioł, w skarbcu kościelnym, wys. $82,2 \mathrm{~cm}$, rzeźba drewniana, drążona od zewnątrz, $z$ nowa polichromia, $z$ tyłu zachowana dawna polichromia w kolorze niebieskim, pod spodem nowej znajduje się zapewne stara. W po- 
zycji frontalnej, stojącej, z rękami złożonymi do modlitwy i dużymi skrzydłami. Szaty srebrnozłote, skrzydla złociste. XVIII w. Barok. Lewe skrzydło przyprawione $\mathrm{w} \mathrm{XX} \mathrm{w}$.

\section{2}

Anioł, w skarbcu kościelnym, wys. 100,5 cm, rzeźba drewniana, drążona od zewnątrz, z nową polichromią olejną, z tyłu zachowała się dawna, jak tė̇ prawdopodobnie pod spodem. W pozycji frontalnej, stojącej na małym postumenciku, $\mathrm{z}$ kręconymi blond włosami, prawa ręka uniesiona w górę, lewa wysunięta do przodu. W srebrzystej tunice i złotej tunicelli. Skrzydła duże, złociste. XVIII w. Barok.

Aniol, w skarbcu kościelnym, wys. 103,5 cm, rzeźba drewniana z olejną polichromią. W pozycji frontalnej, stojącej na małym postumenciku, z rudymi włosami, przepasanymi złotą szarfą, z rękami wyciągnietymi wysoko w górę, z dużymi złocistymi skrzydłami. W złotej tunice przepasanej niebieskim pasem. Pod szyją napis: ECCE AGNUS DEI. XX w. Z Wrocławia. 2 sztuki.

\section{4}

Dobry Pasterz, wys. $65 \mathrm{~cm}$, rzeźba drewniana, polichromowana. $W$ postawie frontalnej, stojącej, przedstawia Jezusa w latach dziecięcych. Prawa ręka wzniesiona w górę, lewa opuszczona do przodu. Z tyłu biała owieczka. Rzeźba o cokoliku $9 \mathrm{~cm}$, umieszczona na feretronie wys. $20,5 \mathrm{~cm}$. $\mathrm{Na}$ froncie podstawy feretronu trzy uskrzydlone główki aniołków.

\section{5}

Anioł, w skarbcu kościelnym, wys. $88 \mathrm{~cm}$, rzeźba drewniana, drążona od zewnątrz, z nową polichromią. W pozycji frontalnej, stojącej, w prawej ręce trzyma poły złocistego płaszcza, wskazującym palcem lewej ręki dotyka ust. Suknia fałdzista, duże pozłacane skrzydła. XVIII w. Barok.

\section{6}

Anioł, w skarbcu kościelnym, wys. $21 \mathrm{~cm}$, rzeźba drewniana, polichromowana olejno na biało. W pozycji siedzącej na kamieniu, na małym postumenciku, z głową lekko pochyloną w dół, z rękami złożonymi do modlitwy, z. dużymi skrzydlami. Prawdopodobnie XIX w.

\section{7}

Aniołek, w skarbcu kościelnym, wys. $24 \mathrm{~cm}$, rzeźba drewniana, polichromowana, pod nową polichromia widoczna dawna. Główka uskrzydlona złocistymi skrzydłami, włosy złote, oczy niebieskie. XVIII w. Barok.

\section{8}

Aniołek, w skarbcu kaścielnym, wys. $42 \mathrm{~cm}$, rzeźba drewniana olejno polichromowana. Korpus ze zlotą przepaską na biodrach, przedstawiony w ruchu, z kręconymi, rudymi włosami, z ręlxami rozłożonymi. XVIII w. Barok. 2 sztuki.

\section{9}

Anioł, w skarbcu kościelnym, wys. $119 \mathrm{~cm}$, rzeźba drewniana, polichromowana. W pozycji klęczącej, na prawym kolanie, na zielonym postumenciku, głowa, $z$ kręconymi blond włosami, uniesiona $w$ górę, prawa ręka wskazującym palcem skierowana w górę, lewa trzyma srebrnạ kotwicę opartą o postument. W tunice, $\mathrm{z}$ duzymi złocistymi skrzydłami. XIX w. 
Aniok, w skarbcu kościelnym, wys. $90 \mathrm{~cm}$, rzeźba drewniana, drążona od zewnątrz, $z$ nową olejną polichromią, pod spodem dawna. W postawie frontalnej, stojącej, $\mathrm{z}$ blond włosami, $\mathrm{z}$ głową odchyloną do tyłu. Prawa ręka wyciągnięta przed siebie w dół, lewa złożona na sercu. Złocisty płaszcz opada pięknymi fałdami $z$ lewego ramienia i okrywa całą postać. Duze złociste skrzydła. XVIII w. Barok.

\section{1}

Pastuszek do szopki na małym postumenciku, w skarbcu kościelnym, wys. $64 \mathrm{~cm}$, rzeźba drewniana, bez polichromii. W pozycji frontalnej, stojącej, $z$ goka, pochyloną głową, w obu rękach trzyma na piersiach kapelusz i laskę, peleryna opada na plecy. Stoi na małym postumenciku. XX w.

\section{2}

Wielki krucyfiks w chórze zakonnym, wys. korpusu ok. $188 \mathrm{~cm}$, rozpiętość rųk ok. $170 \mathrm{~cm}$, rzeźba drewniana, polichromowana. Głowa w cierniowej koronie, opuszczona w prawo i przechylona lekko $w$ dól, fałdy białego perizonium opadają $\mathrm{z}$ prawej strony. Wyrzeźbił o. Franciszek z Pescji, Giovan Pietro Marchi, kapucyn w r. 1719. Barok.

Bibliografia: AKK, rkps HCC, I s. 31. - AKK, rkps 38: Inwentarz z r. 1839 k. 6. - AKK, rkps 39: Inwentarz z r. 1821 k. 26. - APK, rkps O. K. G a d a c z: Historia klasztoru s. 22. - APK, rkps - O. P. Koch ański: Kościół Zwiastowania s. 71. - O. W. Nowakow ski: Pamiątka s. 25. O. K. Gadacz: Inwentarz Archiwum s. 108.

\section{3}

Chrystus Urzyżowany na parterze, wys. korpusu $110 \mathrm{~cm}$, rozpiętość rąk $107 \mathrm{~cm}$, rzeźba drewniana, polichromowana. Glowa przechylona w lewo i opuszczona lekko $w$ dół, włosy długie, opuszczone na plecy, fałdy perizonium opadaja $\mathrm{z}$ obu stron. Korpus przez środek w kierunku pionowym pęknięty. XVIII w. Barok.

\section{4}

N. Maria P. Niepokalanie Poczęta, stojąca na cokole na wirydarzu klasztornym, wys. figury $141 \mathrm{~cm}$, wys. cokołu $137 \mathrm{~cm}$, rzeźba w piaskowcu. W pozycji frontalnej, stojącej, na półkuli opasanej wężem, glowa przechylona lekkso $\mathrm{w}$ prawo i nieco pochylona $\mathrm{w}$ dól, $\mathrm{z}$ rękami złożonymi do modlitwy, $w$ fałdzistej szacie, na głowie welon $z$ wieńcem. Na cokole napis: AVE । MARIA. Dawniej figura stała w miejscu nowego chóru zakonnego i dopiero w r. 1934 została przeniesiona na wirydarz. Figura została odnowiona w r. 1963. Koniec. XIX w.

Bibliografia: AKK, rkps HCC, IV s. 260. - APK, rkps-Br. E, Chmiel: Kronika. s. 350 .

\section{5}

Chrystus Ukrzyźowany, na pierwszym piętrze, wys. korpusu $157 \mathrm{~cm}$, rozpiętość rąk $157 \mathrm{~cm}$, rzeźba drewniana. Glowa przechylona w lewo i opuszczona lekko w dół, z koroną cierniową i czarną brodą, perizonium, umocnione sznurem, opada faldami w środku i $z$ prawej strony. XVIII w.

$$
\because, \quad \mathbf{3 6}
$$

Chrystus Ukrzyżowany, na pierwszym piętrze, wys, korpusu $127 \mathrm{~cm}$, rozpiętość rąk $138 \mathrm{~cm}$, rzeźba drewniana. Głowa przechylona w lewo ze złotą 
aureolą, broda czarna, karpus skropiony krwią, perizonium opada związanym fałdem z prawej strony, powyżej srebrna barokowa tarcza z napisem: INRI. Belki krzyża obite blachą. XVII w. Barok.

Krucyfiks ten znajdował się kiedyś w kaplicy domowej OO. Jezuitów w Ostrogu nad Horyniem. Tradycja jezuicka i przekazy archiwalne opowiadają, że pewien kapłan, skazany na pokutę $w$ klasztorze, odprawiał przed krzyźem mszę św., powtarzając kilka razy werset psalmu: Iudica me, Deus, et discerne causam meam. Głos z krzyża odpowiedział: Iudicavi et iudicabo. Z kolei krzyż przeniesiono do kościoła, gdzie zasłynąl licznymi łaskami. Po kasacie zakonu nadal pozostał w kościele aż do pożaru w r. 1777, w czasie którego ocalał. Wtedy uroczyście został przeniesiony do kościoła parafialnego i umieszczony w specjalnej framudze, na miejsce obrazu Wniebowzięcia N. Marii P W r. 1779 miejscowi bazylianie zabrali krzyż z kościoła $j$ zawiesili w swojej kaplicy domowej. Proboszcz w Ostrogu, ks. bp Franciszek Komarnickı, sufragan diecezji luckiej, zażądał zwrotu krzyża. Wyznaczona przez sąd ziemi łuckiej komisja, przypisała całe zajście swawoli studentów bazyliańskich. Biskup zmarł (ze zmartwienia) 10 maja $1780 \mathrm{r}$. Nowy proboszcz, ks. Józef Umiński, eksjezuita, przejął krzyż w r. 1782, na podstawie wyroku Komisji Edukacyınej, na własność kościoła parafialnego. W r. 1944 tamtejsi kapucyni, aktualni duszpasterze miasta, przewieźli, w ramach repatriacji, cenny zabytek historyczny do klasztoru krakowskiego.

Bibliografia: S. Kardaszewicz: Dzieje dawniejsze miasta Ostroga. Warszawa 1913 s. $175-178,197$.

\section{7}

Chrystus Frasobliwy, na chórku kaplicy Loretańskiej, wys. $61 \mathrm{~cm}$, rzeźba drewniana. W pozycji siedzacej, na postumenciku, w cierniowej koronie, prawą ręką wspiera głowę. Zapewne XIX w.

Bibliografia: APK, rkps - Br. E. Chmiel: Kronika s. 2.

\section{8}

Matka Boska Bolesna ze św. Marią Magdaleną, na chórku kaplicy Loretańskiej, szer. $103 \times 236 \mathrm{~cm}$, plaskorzeźba w drzewie, polichromowana. Matka Boska z twarzą trzy czwarte w lewo, z rękami złożonymi, wokolo głowy aureola ze złotych promieni oraz 6 mieczy, w czerwonej sukni i niebieskim płaszczu. Za nią stoi św. Magdalena, z ręlkami złożonymi na sercu, $z$ aureolą, $z$ wlosami rozpuszczonymi na plecy, w niebieskiej sukni i czerwonym płaszczu. Powyżej niebieskie chmury. Przed r. 1926 plaskorzeźba znajdowała się w oltarzu Chrystusa Ukrzyżowanego, w kaplicy Pana Jezusa, po prawej stronie krucyfiksu. Rzeźbił Romuald Eapczyński z Krakowa. II poł. XIX w.

Bibliografia: APK, rkps - Br. E. Chmiel: Kronika s. 2. - APK, rkps - O. P. Kochańs ki: Kościól Zwiastowania s. 69.

39

Sw. Franciszek $z$ Asyzu, na chórku kaplicy Loretańskiej, szer. $104 \times 236$ $\mathrm{cm}$, płaskorzeźba $\mathrm{W}$ drzewie, polichromowana. W pozycji klęczącej, prawo boczne\}, w brązowym habicie kapucyńskim i białym pasku. Glowa uniesiona w górę, czarna broda i tonsura, prawa ręka opuszczona w dól, lewa wysunięta do przodu. Przed świętym otwarta księga. Powyżej niebieskie chmury i złoty księżyc w pelni. Przed r. 1926 plaskorzé́ba znajdowała się w oltarzu 
Chrystusa Ukrzyżowanego, w kaplicy Pana Jezusa, po lewej stronie krucyfiksu. Rzeźbił Romuald Eapczyński z Krakowa. II poł. XIX w.

Bibliografia - jak pod nr 38 .

40

Matka Boska Loretańska, na pierwszym piętrze, wys. $144 \mathrm{~cm}$, rzeźba drewniana, drążona od zewnątrz. W pozycji frontalnej, stojącej, z Dzieciątkiem Jezus na lewym ręku. Długie, czarne włosy opadają na plecy, oczy niebieskie, w niebieskiej sukni, ze złotymi poziomymi pasami. Dzieciątko prawą rączkę unosi do błogosławienia, w lewej niegdyś trzymało jabłko z krzyżem. Figura została wyrzeźbiona w r. 1890. Do r. 1897 znajdowała się we wnęce ołtarza w kaplicy Loretańskiej.

Bibliografia: AKK, rkps HCC, III s, 119-120. - APK, rkps O. P. Ko c hán s ki: Kościół Zwiastowania s. 72.

\section{1}

Sw. Teresa od Dzieciątka Jezus, na drugim piętrze, szer. $29,5 \times 37 \mathrm{~cm}$, obraz odlany $w$ brązie $z$ podkładem ołowiu, $w$ ozdobnej ramce. W pozycji frontalnej, stojącej, lekko zwrócona w prawo, w obłokach $z$ chmur, z krzyżem $\mathrm{w}$ ręku. Z lewej strony oświetiona promieniami łaski Bożej. I poł. XX w.

\section{2}

Sw. Florian, na pierwszym piętrze, w niszy zewnętrznego narożnika klasztoru, od strony ul. Loretańskiej, wys. ok. $133 \mathrm{~cm}$, rzeźba w piaskowcu. W pozycji frontalnej, stojącej na małym postumencie, w zbroi rycerskiej i helmie, prawą rękę trzyma nad kościółkiem, w lewej dzierży sztandar. Rzeźbił Tadeusz Błotnicki w r. 1903.

43

Sw. Józef z Dzieciątkiem Jezus, w niszy zewnętrznej pierwszego piętra klasztoru, od strony ul. Loretańskiej, rzeźba w piaskowcu, wys. olk. $130 \mathrm{~cm}$. W pozycji frontalnej, stojącej na małym postumencie, w długiej powłóczystej szacie z pięknymi fałdami. W prawej ręce trzyma Dzieciątko, lewa złożona na sercu. Wykonał Tadeusz Błotnicki w r. 1903.

\section{4}

Sw. Jan chrzczący Pana Jezusa, rzeźba w refektarzu, w dawnym lawaterzu, obecnie zamurowanym, wys. kilkanaście $\mathrm{cm}$, rzeźba drewniana. W r. 1787 o. Szymon Sikorski, gwardian klasztoru, przeniósł lawaterz marmurowy z refektarza do zakrystii, a lawaterz zakrystyjny do refektarza. W lawaterzu złożono wtedy male figury, darowane przez ks. Józefa Alojzego Putanowicza. W r. 1937 lawaterz, wraz z rzeźbami. został zamurowany na polecenie gwardiana o. Brunona Moskala.

Bibliografia: AKK, rkps HCC, I s, 209, 289-290. - AKK, rkps 38: Inwentarz z r: 1839 k. 9. - APK, rkps - Br, E. Ch mie 1: Kronika s. 9-10.

$$
\text { (C. d. n.) }
$$

